NBER WORKING PAPER SERIES

\title{
SHROUDED COSTS OF GOVERNMENT: \\ THE POLITICAL ECONOMY OF STATE AND LOCAL PUBLIC PENSIONS
}

\author{
Edward L. Glaeser \\ Giacomo A. M. Ponzetto \\ Working Paper 18976 \\ http://www.nber.org/papers/w18976
NATIONAL BUREAU OF ECONOMIC RESEARCH
1050 Massachusetts Avenue
Cambridge, MA 02138 \\ April 2013
}

Ponzetto gratefully acknowledges financial support from the Spanish Ministry of Science and Innovation (grants ECO-2011-25624 and Juan de la Cierva JCI-2010-08414), the Barcelona GSE Research Network and the Generalitat de Catalunya (grant 2009 SGR 1157). The views expressed herein are those of the authors and do not necessarily reflect the views of the National Bureau of Economic Research.

At least one co-author has disclosed a financial relationship of potential relevance for this research. Further information is available online at http://www.nber.org/papers/w18976.ack

NBER working papers are circulated for discussion and comment purposes. They have not been peerreviewed or been subject to the review by the NBER Board of Directors that accompanies official NBER publications.

(C) 2013 by Edward L. Glaeser and Giacomo A. M. Ponzetto. All rights reserved. Short sections of text, not to exceed two paragraphs, may be quoted without explicit permission provided that full credit, including (๑) notice, is given to the source. 
Shrouded Costs of Government: The Political Economy of State and Local Public Pensions Edward L. Glaeser and Giacomo A. M. Ponzetto

NBER Working Paper No. 18976

April 2013

JEL No. H55,H75

\begin{abstract}
$\underline{\text { ABSTRACT }}$
Why are public-sector workers so heavily compensated with pensions and other non-pecuniary benefits? In this paper, we present a political economy model of shrouded compensation in which politicians compete for taxpayers' and public employees' votes by promising compensation packages, but some voters cannot evaluate every aspect of compensation. If pension packages are "shrouded," meaning that public-sector workers better understand their value than ordinary taxpayers, then compensation will be inefficiently back-loaded. In equilibrium, the welfare of public-sector workers could be improved, holding total public sector costs constant, if they received higher wages and lower pensions. Central control over dispersed municipal pensions has two offsetting effects on pension generosity: more state-level media attention helps taxpayers better understand pension costs, which reduces pension generosity; but a larger share of public sector workers will live within the jurisdiction, which increases pension generosity. We discuss pension arrangements in two decentralized states (California and Pennsylvania) and two centralized states (Massachusetts and Ohio) and find that in these cases, centralization appears to have modestly reduced pension arrangements; but, as the model suggests, this finding is unlikely to be universal.
\end{abstract}

Edward L. Glaeser

Department of Economics

315A Littauer Center

Harvard University

Cambridge, MA 02138

and NBER

eglaeser@harvard.edu

Giacomo A. M. Ponzetto

CREI, Universitat Pompeu Fabra, and Barcelona GSE

C/ Ramon Trias Fargas, 25-27

08005 Barcelona

Spain

gponzetto@crei.cat 


\section{Introduction}

Credit card companies and hotels have charged "shrouded" fees that were difficult for most consumers to assess at the first point of purchase (Gabaix and Laibson 2006). States and localities commit to pension obligations that are similarly difficult for voters to assess. NovyMarx and Rauh (2010) argue that states and localities have underestimated the shortfall in pension funding by trillions of dollars because of aggressive assumptions about returns on pension investments, and the continuing debate over their conclusions reinforces the point that pension promises are hard to evaluate (Mitchell and McCarthy 1999). How does the difficulty of evaluating the costs of future obligations impact the level of public wages and benefits, and what institutions lead to better outcomes for taxpayers and public-sector workers?

After discussing the basics of local pension arrangements across the United States in Section 2, in Section 3 we present a political economy model in the spirit of Glaeser, Ponzetto and Shapiro (2005) and Ponzetto (2011). Politicians compete for votes by making binding promises about public-sector wages and pensions. These promises ensure that public-sector workers prefer their jobs to the private sector. Housing prices equilibrate to make citizens indifferent about living in the community.

Policy promises are heard by only a portion of the electorate. Generally, we assume that promises about pensions are understood less often than promises about wages. Moreover, we assume that public-sector workers are more aware of these promises than voters generally. We also generally assume that public-sector workers are relatively better informed about pensions than other voters. These assumptions can be justified if taxpayers and publicsector workers both have access to public information sources (the "news"), but public-sector workers also have access to an added information source (the "union"), and all sources have a proportionally lower chance of appropriately reporting pension promises relative to wage promises.

Unlike Gabaix and Laibson (2006), we do not assume that uninformed voters underestimate the value of the costs that they do not hear. The ignorant correctly infer what the politicians will do. Still, as in Glaeser, Ponzetto and Shapiro (2005), their ignorance impacts the political equilibrium because politicians cannot change the voting behavior of the ignorant by changing their promises. Our core political results would not change if uninformed voters naively underestimated future pension costs, as long as the marginal home buyer correctly anticipates the cost of pension obligations. Indeed, we suspect that a model with less rationality would only strengthen our results.

As politicians are inherently identical in the model, a variant of the standard median voter result holds, and both politicians choose identical promises. (A slight perturbation of the model, following our earlier work, would give one of the politicians privileged communications with public sector unions and that would lead to policy divergence between the candidates, where the politician with extra access promised more generous pensions). The pensions and wages offered by politicians reflect two first-order conditions that essentially set the benefits that workers get against the cost imposed on taxpayers. The costs and benefits for the two groups are multiplied by the size of the group in the informed voting population. Some public-sector workers live outside the community, and this lowers their political clout, but public-sector workers are better informed and this effect increases their importance in the 
politicians' calculus.

If relatively more union voters understand pension promises, then this pushes the equilibrium towards greater pension obligations. When public-sector workers have a greater advantage over taxpayers in understanding pensions than wages, public-sector consumption is higher post-retirement and public-sector workers would borrow against their future pensions if they could. We don't allow such borrowing, because public pensions typically cannot be taken in bankruptcy. If borrowing against pensions was extremely easy, then public workers would receive no wages and receive all of their compensation in the form of pension promises.

The informational advantages of public-sector workers cause them to earn rents or quasirents, and the political equilibrium leads to a situation in which voters and public-sector workers could both benefit from a different age-earnings profile for public-sector workers. If public-sector workers earned higher wages while young in exchange for lower pension benefits, their welfare could improve at no cost to the taxpayer. Fitzpatrick (2012) finds that Illinois teachers choose not to forgo cash today in exchange for future pensions that have a substantially higher net present value (evaluated at market interest rates).

If pension promises are not fully funded by current taxes, then pension promises decrease housing prices, but if housing supply growth is positive, the drop in the home values for current owners does not fully capture the cost of pension promises. Some of the costs of future pensions will be paid for by the owners of houses that have not yet been built, which means that less fully funded pensions cost current taxpayers less. We assume that vacant land doesn't have votes attached to it; the impact of pre-funding requirements disappears when we assume that there is no housing supply growth in the area. As long as housing growth is positive, the model predicts that pre-funding requirements for pensions will lead to lower pensions, but have no impact on overall public-sector wages, which causes public-sector worker welfare to decline and housing prices to increase.

The spatial equilibrium structure of the model means that we can separately analyze the impact of higher reservation utility, which reflects the general level of prosperity in the country as a whole, and higher private incomes in the area, which will be offset by higher housing prices. Higher incomes lead to higher public-sector wages, because they cause the cost of housing to increase and that increases the marginal benefit to public-sector workers of receiving higher wages, while leaving the marginal cost to taxpayers untouched, since their real incomes are determined by the reservation utility. We assume that workers move when they retire, so higher incomes have no impact on the cost of living when old, and therefore no impact on pensions. An increase in the cost of living in the retirement community does, however, increase pension benefits.

Increases in the reservation utility, however, cause benefits to rise and have an ambiguous impact on wages. The ambiguous effect reflects two opposite effects. Higher reservation utility means that taxpayers have a lower marginal utility of income, reducing the cost of pensions to them, but it also reduces housing prices, causing the marginal benefit of wages to public-sector workers to fall as well.

As the share of public-sector workers that live in the community rises, the amount paid to public-sector workers in both wages and pensions also increase, because the political power of the public-sector workers has risen. As the informational advantage of the public-sector workers about wages falls, public-sector wages falls and so do pensions. As the informa- 
tional advantage of the public-sector workers about benefits falls, benefits fall but wages stay constant. The asymmetry between knowledge of wages and benefits reflects the fact that lower public-sector wages (caused by better taxpayer knowledge about wages) increase the marginal utility cost to the public workers of paying for their own pensions by decreasing their consumption while young. Lower public-sector pensions, however, do not impact their marginal utility of consumption when young, because the tax benefit of lower pension payments are completely offset by higher housing costs.

In section 4, we use these results to discuss the impact of allocating control over public pensions to the state or to lower levels of government. We assume that there are two offsetting effects of allocating control to a higher level of government. First, there are state media sources that will supplement the knowledge about pensions and wages at the local level. Our information structure implies that this greater knowledge will increase the knowledge of taxpayers about both wages and pensions, but it will have a greater impact on knowledge of pensions because that knowledge started at a lower level. We also assume that the share of public-sector workers who vote in the relevant election increases, since public-sector workers are quite likely to live in the state where they work, but they are far less likely to live in the community where they work.

The overall impact on wages and pensions depends on which effect dominates. If the impact of public-sector workers voting is more powerful, then state control will lead to more generous wages and pension benefits. If the impact of reduced information asymmetries between voters and workers is stronger, then state pensions and wages will be less generous. If the local news sources provide at least a modest amount of information, then moving to the state level will lead to a flattening of the consumption profile for state workers, because of the reduced asymmetry between wage and pension knowledge. This flattening means that if the move to state control held housing values constant, public-sector workers would be unambiguously better off.

In section 5, we turn to four real world examples of states with different pension arrangements, both to understand why different systems evolve and to examine the impact of those systems. We compare two pairs of states: Massachusetts and California, and Ohio and Pennsylvania. We cover the first two in some detail and briefly discuss the second pair. Both pairs include a state with a central, state-level control over local pensions (Massachusetts and Ohio) and a state with abundant local heterogeneity in county and municipal pensions (California and Massachusetts).

Massachusetts had a modest number of local pensions prior to World War II, but in 1945 the state passed a law which controlled the terms of local pension arrangements. While localities, somewhat oddly, continue to have control over investment decisions, the basic generosity of the pension plans is set at the state level. Moreover, the state has regularly reacted to perceived funding shortfalls by requiring higher levels of employee contributions. California's local pension plans are regulated at the state level, but counties and localities have discretion over the generosity of the plan, within limits, whether the plan is independent (like many of the county plans) or part of the broader CalPERS system. We speculate that California's decision to allow local heterogeneity reflected a lack of enthusiasm for an earlier 1919 attempt to generate widespread local pension schemes, and a recognition of the enormous heterogeneity within the large state.

Both California and Massachusetts have generous pension arrangements, but California's 
local plans are typically more generous. The difference is not so much that the California pensions provide less compensation in retirement, but rather that the Massachusetts plans require significantly higher levels of member contribution.

Ohio's local plans were centralized in 1967, in response to an early under-funding requirement. The program also provides large pensions, but it has a 10 percent member contribution rate, which is slightly above Massachusetts. Pennsylvania has great heterogeneity in plan generosity. We consider Luzerne County, which is only slightly more generous than Ohio, and Pittsburgh, which is considerably more generous. Again, the main gap in generosity reflects differences in member contributions.

It is difficult to draw too much inference from four case studies, but in these cases central control seems to have led to lower pensions. To us this suggests the power of shrouding, because a primary difference between state and local control is that more media attention tends to be paid to pensions at the state level than purely local pension arrangements. We do not, however, believe that this is a universal phenomenon.

We now turn to some basic facts about local pension arrangements across the United States and then present our model.

\section{State and Local Public Pensions}

In this section, we survey the heterogeneity in local and pension plan arrangements across the United States. Our focus is on municipal pension plans, but we discuss state plans as well, because we believe they shed light on what would happen in towns and municipalities if their pensions were determined at the state level. This discussion provides the institutional basis for the model that follows in the next section.

America's fifty states have fifty different arrangements concerning state and municipal pensions. There are, however, common features across the country. Table 1 briefly summarizes the state and local plans for all fifty states. Almost all of states have state-level pension programs covering the direct employees of the state. In most cases, there is also an umbrella organization that some or all municipalities join. CalPERS, the California Public Employees Retirement System, may be the most famous example of such a super-system, as the nation's largest public pension fund, with over $\$ 200$ billion dollars of assets under management. Many of these programs also deal with healthcare costs, but we will not focus on the abundantly studied issues around healthcare costs in this paper.

Teachers, who typically represent a large share of municipal employment, often have their own statewide systems that are distinct from, if often quite similar to, the more general state program. Often the teacher systems are at once a part of and independent from the state system. The California State Teacher Retirement System, CalSTRS, has $\$ 150$ billion under management, making it another financial behemoth. But unlike the CalPERS plan for localities, participation in CalSTRS is obligatory for every school district and every school teacher, and every teacher faces exactly the same defined benefit program. That program is financed primarily with employer and employee contributions, currently at 8.25 and 8 percent of compensation respectively. The state also makes contributions.

By contrast, participation in CalPERS, as in many state-level municipal programs, is voluntary, and the municipalities that do participate have the option to contract tailored 
programs with CalPERS. As a result, some California plans are considerably more generous than others. The California system lies somewhat in the middle of American states in the degree of autonomy its grants to localities.

The most centralized state systems, such as South Dakota and Utah, enroll all municipal employees in a statewide system, managed down to every detail at the state level. These states have not eliminated local negotiation over wages, or other working conditions, but the pension payments are fixed at the state level. Both localities and workers must contribute a proportion of their wages, and retired workers receive payments that are determined by a formula based on past compensation and other factors, including years of service and age of retirement. Even within these statewide systems, however, there are sector-specific pension differences for different groups such as teachers, policemen and firefighters.

In these states, there is no distinction between the state system and the municipal system, but in most of America, the local systems - even if managed at the state level-have their own characteristics. For example, Minnesota has a statewide Public Employees Retirement Association for employees of local government, but this is distinct from the Minnesota State Retirement System, which manages retirement for the state's own workers. The Minnesota system sets terms, mandates payments and manages the system's investments.

The next level of centralization occurs in states, like Massachusetts, that have a state system which is officially voluntary, but does in fact manage all, or almost all (Boston is excluded), of the local systems. Somewhat bizarrely, even though Massachusetts sets the terms of pensions and mandates employer and employee contributions to investment funds, over 50 localities continue to maintain control over the investments related to their public pensions.

Massachusetts is at one end of a spectrum of "voluntary" statewide programs, some of which are virtually universal while some have far more sporadic membership. Each state followed a different path towards their system, and provided different incentives or rules for joining the statewide system (when it exists). In the majority of these systems, terms are set centrally, but in a number of important systems, even those municipalities that join the central system have discretion over the generosity of plan.

Within CalPERS, local governments can choose whether to have systems that accrue pensions at $1.5 \%$ or $2 \%$ or even $3 \%$ rate; that percentage is multiplied by years of service to determine the pension as a share of final compensation (subject to a maximum). Texas, Oklahoma and Tennessee also allow discretion in the nature of the plan. Localities face a menu, and then subject to the political process and bargaining with employees, choose their preferred option.

Those localities that participate in statewide systems also face clear funding requirements set at the state level. Historically, some systems once operated as pay-as-you-go systems, requiring only that localities pay for the current year's retired employees. Funding shortfalls, especially in the 1980s, caused many states to switch to somewhat more conservative systems, often moving gradually towards "full funding." Of course, full funding is often calculated using extremely high expected rates of return that still leave the possibility of substantial cash shortfalls.

Completely local pension systems would seem to be the extreme of decentralization, but even in that case, the state government can still exercise a fair amount of control over local pensions. Cities have no independent constitutional rights; they are always creatures 
of state government. For example, every one of California's county pension system is a matter of state law, even though the pensions have different terms that were determined by collective bargaining at the state level. State law also governs the pensions of Boston and New York. Yet in most cases, even thought the state does exercise ultimate legislative power, the legislature will often defer to the city's wishes.

Another dramatic difference across states comes from their participation in Social Security. When Social Security was originally established, constitutional issues deterred any attempt to involve lower levels of government. The Federal government did not appear to have the power to compel states and municipalities to contribute to any sort of pension system for their employees, and as a result they were completely excluded from Social Security. In the 1950s, Congress made it possible for states to enter voluntarily into Social Security, and the majority of states have taken that option. Still, Table 1 notes those states that have remained outside of the Social Security system, including Massachusetts.

Using funding ratios from Novy-Marx and Rauh (2009), which provide only a combined estimate for states and localities, we did not see a clear linkage between the level of funding and the degree of local control, perhaps because the bulk of the funding concerns state employees. We believe that further investigation of this topic is a pressing area for future research.

Table 2 compares the average yearly earnings of employees in the state in 2011 and the average benefits paid to retired state employees in 2010. The wages are calculated across all employees in the state using the 2010 Census. The benefits are calculated using the Census report on state and local pension funds that reports benefits paid and beneficiaries. These numbers do little to control for pension retiree characteristics, or even whether the state participates in Social Security, so they can only be seen as very coarse numbers. We have also calculated the ratio of retirement earnings of state workers to current workers' earnings in the next column.

In Figure 1, we show the correlation of benefits per beneficiary and state wages. There is a strong positive correlation but the relationship is far from perfect. If these numbers are in any way correct, they suggest that some states are more generous than others, even holding state income levels constant. One of the goals of our model is to provide a framework that can help explain those differences.

\section{A Political Economy Model of Public Pensions}

In this section, we present our core model of the political economy of public-sector pensions. In the next section, we specifically focus on the issues that relate to central and local control of pension promises. There are several key assumptions in the model. Perhaps the most critical assumption is that pension promises are "shrouded." While this model is in the spirit of Gabaix and Laibson (2006), applying their logic to the public sector, we are not assuming any irrationality. Our voters do expect to pay workers' pensions, but not every voter is aware of the pensions promised by individual politicians. They are ignorant, but not irrational.

Some voters are also unaware of wage promises, but we assume that understanding the magnitude of pension obligations is somewhat more difficult than understanding current 
compensation. The logic of the model, therefore, should extend to any complex form of compensation including health-related benefits. We also assume that public-sector workers know more about pensions and wages than ordinary voters. Technically, we assume that workers and taxpayers both have access to the same news-related sources of information, but public-sector workers also have access to an added source of information: the "union." In reality, workers should know more about their compensation packages because they have far stronger incentives to understand these packages than voters.

Another key assumption is that public-sector workers cannot freely borrow against future pensions. This assumption ensures that pensions are not a perfect substitute for wages from the workers' perspective. In the case of other forms of shrouded compensation, there could be other reasons why workers would prefer cash to the benefit. Workers might, for example, just not value health benefits at their cost.

We also impose several less critical assumptions. There is a prefunding requirement imposed exogenously on government pensions. All public-sector workers vote in state elections, but only a fraction vote in local elections, because they are assumed to live outside of the locality. State workers earn rents (or potentially quasi-rents) and as such there must be a rationing device, which we assume is a lottery that occurs before the start of the model.

\subsection{Economic Environment}

In its basic structure, the model follows an overlapping generations setup. When young, individuals choose their location and they must be indifferent between living in that location and locating someplace else. This indifference condition means that changes in pensions, or institutional conditions that impact public-sector compensation, do not impact the welfare of these citizens, but they will impact housing prices in the city, which adjust to compensate residents for expected future tax payments. Indeed, we will follow the Henry George theorem (Arnott and Stiglitz, 1979) and treat the value of land at the beginning of time as one measure of welfare. However, the equivalence between housing prices and welfare in this setting only holds if we assume that the rents earned by public-sector workers have been dissipated through some early competition for public-sector jobs, which we do not model.

An exogenous fraction $q<1 / 2$ of workers have won the public-sector lottery and can work for a particular local government. All winners take that option, but only a fraction $\gamma \in(0,1]$ of them live in the city. This proportion will critically determine their political clout in the city. In principle, there is a participation constraint that requires local governments to provide sufficient compensation to make that decision optimal, but that constraint only binds in limit cases. ${ }^{1}$

There is an exogenously determined stock of housing in the city that grows at a constant rate $\delta \geq 0$. We assume that this reflects a fixed regulatory growth limit on new construction. This assumption could also be justified by assuming that there is a cost of construction that is increasing with the amount of construction, but in an endogenous construction model, the rate of growth would be a function of pension promises. By assuming exogenous growth, we

\footnotetext{
${ }^{1}$ Formally, the constraint is never binding when policy is centrally set at the state level. Under decentralized local policy-making, it is also non-binding provided that a minimum of public sector employees vote in the local election.
} 
break that link. The number of people equal the number of homes, so population grows at the same rate $\delta$ as the housing stock.

Private-sector workers earn a fixed location-specific income $Y$ when they are young; they must save to consume during their retirement. Public-sector workers earn wages $w_{t}$ while young and may also be paid a pension benefit $B_{t+1}$ when they are older. Private- and publicsector workers pay for the cost of public-sector wages with lump sum taxes. Since houses are the same, we could also think of these taxes as property taxes. Proportional taxes on housing value will have an equivalent impact on initial housing prices as lump-sum taxes since both imply the same tax burden.

Taxpayers and current public-sector workers also pay for the unfunded portion of pensions paid to last period's workers, who are now retired, and the funded portion of pensions that will be paid to current workers during the next period. Specifically, we assume that a fixed proportion $\phi \in[0,1]$ of pension obligations must be prefunded. Funds that are set aside to pay future pensions earn the market rate of return $r>\delta$ and are given to retired public-sector workers during the next period. Taxes in period $t$ thus equal

$$
T_{t}=q\left(\frac{1-\phi}{1+\delta} B_{t}+w_{t}+\frac{\phi}{1+r} B_{t+1}\right) .
$$

People live in the city when they are young and retire elsewhere when they are old. The cost of housing during retirement is an exogenous amount $R$. At the start of each period $t$, the retiring old workers sell their homes to young workers at the current price $H_{t}$. The newly-built houses are sold by developers to the young. Each buyer can take out a mortgage for the full amount $H_{t}$. He will repay the principal in the following period, but must pay interest $H_{t} r /(1+r)$ while living in the house.

Therefore, public-sector workers in period $t$ have disposable income

$$
C_{W, t}^{P}=w_{t}-T_{t}-\frac{r}{1+r} H_{t}
$$

and when retired in the following period $t+1$ they have disposable income

$$
C_{R, t+1}^{P}=B_{t+1}+H_{t+1}-H_{t}-R \text {. }
$$

These disposable incomes also coincide with public-sector employees' consumption level when their borrowing constraint binds, as it always does in equilibrium.

Private-sector workers, which we will also refer to as taxpayers even if public-sector workers pay identical taxes, have a disposable income net of lifetime housing costs

$$
A_{t}^{T}=Y-T_{t}-H_{t}+\frac{H_{t+1}-R}{1+r} .
$$

They optimally choose their savings given current taxes $T_{t}$ and rational expectations of future policy, which enable perfect foresight of future house prices $H_{t+1}$.

All agents have intertemporally separable logarithmic utility with a discount factor $\beta \in$ $(0,1]$ :

$$
U_{t}=\log C_{W, t}^{i}+\beta \log C_{R, t}^{i} .
$$


The optimal consumption path is then

$$
C_{R, t+1}^{i}=\beta(1+r) C_{W, t}^{i}
$$

Hence, public-sector workers face a binding borrowing constraint whenever

$$
C_{R, t+1}^{P}>\beta(1+r) C_{W, t}^{P}
$$

Private citizens optimally choose

$$
C_{W, t}^{T}=\frac{A_{t}^{T}}{1+\beta} \text { and } C_{R, t+1}^{T}=\frac{\beta(1+r)}{1+\beta} A_{t}^{T},
$$

so their total lifetime utility equals

$$
U_{t}^{T}=(1+\beta) \log A_{t}^{T}-(1+\beta) \log (1+\beta)+\beta \log \beta+\beta \log (1+r) .
$$

The model contains a critical spatial indifference condition: citizens must be indifferent between living in the community or not. This condition implies that housing prices $H_{t}$ must be such that the anticipated utility of living in the city for those who have lost the public employment lottery equals a constant reservation utility $\bar{U}$. For the sake of notation, define the equivalent reservation income

$$
\bar{A} \equiv(1+\beta)[\beta(1+r)]^{-\frac{\beta}{1+\beta}} e^{\frac{\bar{U}}{1+\beta}} .
$$

Spatial indifference then requires that in equilibrium

$$
Y-T_{t}-H_{t}+\frac{H_{t+1}-R}{1+r}=\bar{A}
$$

\subsection{The Politicians' Problem}

The model contains one key optimization problem: the political choice of public-sector compensation policies $w_{t}$ and $B_{t+1}$. We model policy-making as the outcome of an electoral process with binding platform commitments but imperfectly and heterogeneously informed voters, following Ponzetto (2011).

The election is contested by two parties, labelled $L$ and $R$, whose only goal is to win office and which accordingly choose their policy proposals to maximize the probability of obtaining a majority of the votes cast. The electorate consists of a continuum of voters, whose total mass can be normalized to unity each period. Following the probabilistic-voting approach (Lindbeck and Weibull 1987), voters' preferences for the competing parties comprise two independent elements. Each voter derives utility $U_{t}^{i}\left(w_{t}, B_{t+1}\right)$ from the policy vector $\left(w_{t}, B_{t+1}\right)$ enacted by the winner of the election. Moreover, the two parties have fixed characteristics, such as ideology or the personal qualities of party leaders, that cannot be credibly altered with the choice of an electoral platform; and the voters have individual tastes, respectively $\xi_{L}^{i}$ and $\xi_{R}^{i}$, for these characteristics.

In the standard probabilistic-voting model, parties choose binding policy platforms and all voters perfectly observe them. We relax the assumption of perfect information, and 
instead consider a random process of imperfect information acquisition. Information arrives independently across agents. By the time the election is held, voter $i$ has observed all proposals with probability $\theta_{w \wedge B}^{i}$, only wage proposals with probability $\theta_{w \neg B}^{i}$, only pension proposals with probability $\theta_{B \neg w}^{i}$, and no actual proposals at all with complementary probability $1-\theta_{w \wedge B}^{i}-\theta_{w \neg B}^{i}-\theta_{B \neg w}^{i}$. A microfounded derivation of these probabilities for taxpayers and public-sector workers is detailed below.

Let $\left(\hat{w}_{t}^{C, i}, \hat{B}_{t+1}^{C, i}\right)$ denote voter $i$ 's rational beliefs about the policies that each candidate $C \in\{L, R\}$ has proposed and would enact if elected. For the proposals $i$ observed, these beliefs coincide with the candidates' actual choices $w_{t}^{C}$ and $B_{t+1}^{C}$. For the proposals $i$ didn't observe, these beliefs coincide instead with the ex ante rational expectations of policy proposals $\bar{w}_{t}$ and $\bar{B}_{t+1}$. These expectations are identical for the two candidates because voters understand that both parties have the same objective of winning office and face identical incentives.

Given his information, voter $i$ votes for party $R$ if and only if

$$
U_{t}^{i}\left(\hat{w}_{t}^{L, i}, \hat{B}_{t+1}^{L, i}\right)+\xi_{L}^{i} \leq U_{t}^{i}\left(\hat{w}_{t}^{R, i}, \hat{B}_{t+1}^{R, i}\right)+\xi_{R}^{i}
$$

An individual's relative assessment of the two candidates' non-policy characteristics can be disaggregated into a common and an idiosyncratic component: $\xi_{L}^{i}-\xi_{R}^{i}=\Psi+\psi^{i}$. Both $\Psi$ and $\psi^{i}$ are unobservable to politicians, and independently drawn from common-knowledge probability distributions. The common shock $\Psi$ accounts for the aggregate uncertainty in the electoral outcome. The idiosyncratic shock $\psi^{i}$ provides the intensive margin of political support, and is independent and identically distributed across agents. For the sake of clarity, we assume that $\psi^{i}$ has a uniform distribution with support $[-\bar{\psi}, \bar{\psi}]$ sufficiently wide that each voter's ballot is not perfectly predictable on the basis of policy considerations only. ${ }^{2}$

Voters are divided into two groups: fraction $\gamma q$ of public-sector workers, and fraction $1-\gamma q$ of taxpayers. All members of either group $j \in\{P, T\}$ have an identical utility function $U_{t}^{j}\left(w_{t}, B_{t+1}\right)$ and identical information-acquisition probabilities $\theta_{w \wedge B}^{j}, \theta_{w \neg B}^{j}$, and $\theta_{B \neg w}^{j}$. Since there is a continuum of agents of either type and the arrival of information is independent across agents, these probabilities coincide with the shares of voters from each group that have observed proposals respectively for both policies or for each one alone.

Given the realization of the common shock $\Psi$, the fraction of citizens of type $j$ who vote for party $R$ equals

$$
s_{R}^{j}=\frac{1}{2}+\frac{1}{2 \bar{\psi}}\left(\left\{\begin{array}{c}
\theta_{w \wedge B}^{j}\left[U_{t}^{j}\left(w_{t}^{R}, B_{t+1}^{R}\right)-U_{t}^{j}\left(w_{t}^{L}, B_{t+1}^{L}\right)\right] \\
+\theta_{w \neg B}^{j}\left[U_{t}^{j}\left(w_{t}^{R}, \bar{B}_{t+1}\right)-U_{t}^{j}\left(w_{t}^{L}, \bar{B}_{t+1}\right)\right] \\
+\theta_{B \neg w}^{j}\left[U_{t}^{j}\left(\bar{w}_{t}, B_{t+1}^{R}\right)-U_{t}^{j}\left(\bar{w}_{t}, B_{t+1}^{L}\right)\right]
\end{array}\right\}-\Psi\right) .
$$

Thus the realization of $\Psi$ determines the number of ballots cast for each candidate: party $R$

\footnotetext{
${ }^{2}$ This assumption simplifies the analytical derivations but hardly involves a loss of generality. In a symmetric pure-strategy Nash equilibrium of the platform-proposal game the policy proposals are independent of the specific distribution of $\psi_{i}$.
} 
receives more votes than party $L$ if and only if

$$
\begin{aligned}
\Psi<\gamma q\left\{\begin{array}{c}
\theta_{w \wedge B}^{P}\left[U_{t}^{P}\left(w_{t}^{R}, B_{t+1}^{R}\right)-U_{t}^{P}\left(w_{t}^{L}, B_{t+1}^{L}\right)\right] \\
+\theta_{w \neg B}^{P}\left[U_{t}^{P}\left(w_{t}^{R}, \bar{B}_{t+1}\right)-U_{t}^{P}\left(w_{t}^{L}, \bar{B}_{t+1}\right)\right] \\
+\theta_{B \neg w}^{P}\left[U_{t}^{P}\left(\bar{w}_{t}, B_{t+1}^{R}\right)-U_{t}^{P}\left(\bar{w}_{t}, B_{t+1}^{L}\right)\right]
\end{array}\right\} \\
+(1-\gamma q)\left\{\begin{array}{c}
\theta_{w \wedge B}^{T}\left[U_{t}^{T}\left(w_{t}^{R}, B_{t+1}^{R}\right)-U_{t}^{T}\left(w_{t}^{L}, B_{t+1}^{L}\right)\right] \\
+\theta_{w \neg B}^{T}\left[U_{t}^{T}\left(w_{t}^{R}, \bar{B}_{t+1}\right)-U_{t}^{T}\left(w_{t}^{L}, \bar{B}_{t+1}\right)\right] \\
+\theta_{B \neg w}^{T}\left[U_{t}^{T}\left(\bar{w}_{t}, B_{t+1}^{R}\right)-U_{t}^{T}\left(\bar{w}_{t}, B_{t+1}^{L}\right)\right]
\end{array}\right\} .
\end{aligned}
$$

For any distribution of the unobservable common shock $\Psi$, party $R$ seeks to maximize the right-hand side, and party $L$ to minimize it. This leads both parties to solve the same problem:

$$
\max _{w_{t} B_{t+1}}\left\{\begin{array}{l}
\gamma q\left[\theta_{w \wedge B}^{P} U_{t}^{P}\left(w_{t}, B_{t+1}\right)+\theta_{w \neg B}^{P} U_{t}^{P}\left(w_{t}, \bar{B}_{t+1}\right)+\theta_{B \neg w}^{P} U_{t}^{P}\left(\bar{w}_{t}, B_{t+1}\right)\right] \\
+(1-\gamma q)\left[\theta_{w \wedge B}^{T} U_{t}^{T}\left(w_{t}, B_{t+1}\right)+\theta_{w \neg B}^{T} U_{t}^{T}\left(w_{t}, \bar{B}_{t+1}\right)+\theta_{B \neg w}^{T} U_{t}^{T}\left(\bar{w}_{t}, B_{t+1}\right)\right]
\end{array}\right\} .
$$

Let $\theta_{w}^{i} \equiv \theta_{w \wedge B}^{i}+\theta_{w \neg B}^{i}$ denote the probability that voter $i$ observes wage proposals, regardless of his observation of pension proposals, and analogously $\theta_{B}^{i} \equiv \theta_{w \wedge B}^{i}+\theta_{B \neg w}^{i}$. The derivation above immediately implies the following characterization of equilibrium policy.

Lemma 1 In a rational expectations equilibrium, the political optimality condition for publicsector wages is

$$
\gamma q \theta_{w}^{P} \frac{\partial U_{t}^{P}}{\partial w_{t}}\left(w_{t}, B_{t+1}\right)+(1-\gamma q) \theta_{w}^{T} \frac{\partial U_{t}^{T}}{\partial w_{t}}\left(w_{t}, B_{t+1}\right)=0
$$

and simultaneously the political optimality condition for public-sector pensions is

$$
\gamma q \theta_{B}^{P} \frac{\partial U_{t}^{P}}{\partial B_{t+1}}\left(w_{t}, B_{t+1}\right)+(1-\gamma q) \theta_{B}^{T} \frac{\partial U_{t}^{T}}{\partial B_{t+1}}\left(w_{t}, B_{t+1}\right)=0 .
$$

Rational voters can anticipate the equilibrium platforms of the two parties with perfect foresight $\left(\bar{w}_{t}=w_{t}^{C}\right.$ and $\bar{B}_{t+1}=B_{t+1}^{C}$ for $\left.C \in\{L, R\}\right)$. Yet, politicians' strategies are driven by imperfect and heterogeneous information off the equilibrium path. An uninformed agent correctly anticipates the equilibrium proposals, but he would fail to notice a deviation from the expected policy choice, and thus could not react to such a deviation when casting his vote. Politicians optimally set each policy $w_{t}$ and $B_{t+1}$ to cater disproportionately to the preferences of those voters who are disproportionately likely to observe the respective proposal, because only those voters' ballots reflect directly the policy commitments.

\subsection{Voter Information}

Lemma 1 establishes that whenever public-sector workers are more informed about their compensation than other taxpayers $\left(\theta_{w}^{P}>\theta_{w}^{T}\right.$ and $\left.\theta_{B}^{P}>\theta_{B}^{T}\right)$, they obtain a more generous treatment than their mere numbers would warrant. Furthermore, if their informational advantage is greater for pensions than wages $\left(\theta_{w}^{P} / \theta_{w}^{T}<\theta_{B}^{P} / \theta_{B}^{T}\right)$, public-sector pensions are 
more generous than public-sector wages. We shall now prove that this pattern of information asymmetry emerges from a simple process of information acquisition.

Information about policy proposals is provided to all voters by local news sources. Each agent receives information about wage proposal from the news with probability $\underline{\theta}_{L} \in(0,1)$. The probability of receiving information about proposed pension is $\pi \underline{\theta}_{L}$ for $\pi \in(0,1)$, capturing our fundamental assumption that pension obligations are "shrouded." $\pi<1$ reflects directly lower availability of information about pensions than wages. State employees' salaries are publicly disclosed every year, and can be easily consulted through the online edition of local newspapers. ${ }^{3}$ No such database exists for the accruing pensions of currently employed civil servants. Moreover, $\pi<1$ reflects the greater difficulty of understanding the accrual of pension obligations. Thus the parameter allows us to capture with a simple formulation that a voter may be informed of a debate about the cost of public-sector pensions, but still unable to grasp the actual impact of different policy proposals.

In addition to the local news that reach all taxpayers, public-sector workers naturally have more opportunities and greater incentives to become informed of policy proposals concerning their own compensation. Ponzetto (2011) models explicitly the sharing of information about sector-specific policy among co-workers in the workplace, and agents' willingness to make costly investments to acquire sector-specific information. Here we make the simplifying assumption that public employees have access to a second source of news: public-sector unions. In addition to the probability $\underline{\theta}_{L}$ of being informed by the news, and independent of the arrival of such information, every public-sector worker has probability $\underline{\theta}_{U} \in(0,1)$ of being informed of wage proposals by the union. Once again, pensions are less visible, and the relative probability of information through the union is only $\pi \underline{\theta}_{U}$.

This structure implies that the information probabilities for taxpayers are

$$
\theta_{w}^{T}=\underline{\theta}_{L} \text { and } \theta_{B}^{T}=\pi \underline{\theta}_{L}
$$

while those for public-sector workers are

$$
\theta_{w}^{P}=\underline{\theta}_{L}+\underline{\theta}_{U}-\underline{\theta}_{L} \underline{\theta}_{U} \text { and } \theta_{B}^{P}=\pi\left(\underline{\theta}_{L}+\underline{\theta}_{U}\right)-\pi^{2} \underline{\theta}_{L} \underline{\theta}_{U} .
$$

To summarize the distribution of information, we define two measures of symmetry

$$
\rho_{w}=\frac{\theta_{w}^{T}}{\theta_{w}^{P}} \text { and } \rho_{B}=\frac{\theta_{B}^{T}}{\theta_{B}^{P}},
$$

with the following properties (all proofs are provided in the appendix).

Lemma 2 For any policy proposal, public-sector workers are more likely to informed than taxpayers. Their information advantage is greater for pensions than wages $\left(0<\rho_{B}<\rho_{w}<\right.$ 1).

Information asymmetry declines when local news provide more information $\left(\partial \rho_{w} / \partial \underline{\theta}_{L}>\right.$ 0 and $\left.\partial \rho_{B} / \partial \underline{\theta}_{L}>0\right)$ and increases when public-sector unions provide more information

\footnotetext{
${ }^{3}$ E.g., data for Massachusetts are provided by the Boston Herald at http://www.bostonherald.com/projects/your_tax_dollars.bg; for California by the Sacramento Bee at http://www.sacbee.com/statepay/.
} 
$\left(\partial \rho_{w} / \partial \underline{\theta}_{U}<0\right.$ and $\left.\partial \rho_{B} / \partial \underline{\theta}_{U}<0\right)$. When pensions are more shrouded, information about them is more asymmetric $\left(\partial \rho_{B} / \partial \pi>0\right)$.

The relative asymmetry of information about pensions compared to wages is higher when pensions are more shrouded $\left(\partial\left(\rho_{B} / \rho_{w}\right) / \partial \pi>0\right)$ and when either source provides more information $\left(\partial\left(\rho_{B} / \rho_{w}\right) / \partial \underline{\theta}_{L}<0\right.$ and $\left.\partial\left(\rho_{B} / \rho_{w}\right) / \partial \underline{\theta}_{U}<0\right)$.

Intuitively, information acquisition has positive but diminishing returns. Receiving additional news from the union makes public-sector working better informed across the board; the effect is naturally stronger, the more information the union conveys $\left(\partial \rho_{p} / \partial \underline{\theta}_{U}<0\right)$. Moreover, the additional information is more valuable when local news are poorly informative $\left(\partial \rho_{p} / \partial \underline{\theta}_{L}>0\right)$.

Diminishing returns also imply that public employees' informational advantage is always stronger for pension proposals, which are more difficult to get to know and which taxpayers are more likely to ignore $\left(\rho_{B}<\rho_{w}\right)$. Furthermore, its strength is increasing in the degree of shrouding of public-sector pensions (low $\pi$ ). The degree of shrouding affects information asymmetry over pensions but not over wages, so it naturally increases relative asymmetry $\left(\partial\left(\rho_{B} / \rho_{w}\right) / \partial \pi>0\right)$.

Finally, the lemma establish that any increase in informativeness, whether of the news or of the union, makes the two issues more asymmetric $\left(\partial\left(\rho_{B} / \rho_{w}\right) / \partial \underline{\theta}_{L}<0\right.$ and $\partial\left(\rho_{B} / \rho_{w}\right) / \partial \underline{\theta}_{U}<$ $0)$. Intuitively, taxpayers' relative information is fixed at $\theta_{B}^{T} / \theta_{w}^{T}=\pi$, so the effect of greater information plays out only through public employee's relative information $\theta_{B}^{P} / \theta_{w}^{P}$. Hence, more information has the same effect on relative asymmetry regardless of its source. Diminishing returns once more explain why its effect is an increase in relative asymmetry: the additional information has a greater effect on the less visible issue, i.e., pensions.

\subsection{Dynamic Equilibrium}

To solve the model, we must account for the dynamic structure of an overlapping generations economy. With anything short of full prefunding, current pension promises $B_{t+1}$ directly influence future taxes $T_{t+1}$. This connection implies an indirect impact on future house prices $H_{t+1}$ through the spatial indifference condition, and on future wages $w_{t+1}$ and pension promises $B_{t+1}$ through the political optimality conditions.

The timeline within each period $t$ is the following.

1. The city inherits from the previous period binding pension promises $B_{t}$.

2. The house price $H_{t}$ is determined so that taxpayers' spatial indifference condition holds.. The young buy houses and move to the city. The old retire, sell their houses and leave the city.

3. Politicians simultaneously announce binding policy proposals $\left(w_{t}^{C}, B_{t+1}^{C}\right)$. Each voter $i$ is informed of wage proposals with probability $\theta_{w}^{i}$ and of pension proposals with probability $\theta_{B}^{i}$. The election is held.

4. The winning candidate's policy proposal is implemented. Public-sector workers earn wages $w_{t}$, while taxes $T_{t}$ are levied to defray these wages, the unfunded component 
of current pensions $B_{t}$, and the funded component of future pensions $B_{t+1}$. Workers choose how much to save and invest in capital markets.

The period then ends, and the process beings anew for period $t+1$. Period- $t$ voters become old and sell their houses at a price $H_{t+1}$. The link between generations is the joint evolution of pension and house prices.

A dynamic equilibrium is characterized by three functions $H(x), w(x)$ and $B(x)$ such that for any pension obligation $B_{t}=x$ house prices are $H_{t}=H(x)$, public employees' wages $w_{t}=w(x)$ and public-sector pension promises $B_{t+1}=B(x)$ Rational expectations imply that agents correctly anticipate policies $w_{t}$ and $B_{t+1}$ when the house price $H_{t}$ is determined. Crucially, they also correctly anticipate, by iteration, future house prices $H_{t+1}=H(B(x))$.

The spatial equilibrium condition (11) and lemma 1 jointly characterize the dynamic equilibrium. To simplify notation, define a transformed index of voting participation by public-sector employees

$$
\tilde{\gamma}=\frac{\gamma(1-q)}{1-\gamma q} \in[0,1]
$$

which is monotone increasing in $\gamma$ with $\tilde{\gamma}=0 \Leftrightarrow \gamma=0$ and $\tilde{\gamma}=1 \Leftrightarrow \gamma=1$. The three equilibrium functions must satisfy the following three conditions.

1. The spatial indifference condition:

$$
Y-q\left[\frac{1-\phi}{1+\delta} x+w(x)+\frac{\phi}{1+r} B(x)\right]-H(x)+\frac{H(B(x))-R}{1+r}=\bar{A} .
$$

2. The political optimality condition for public-sector wages,

$$
\gamma q(1-q) \frac{\theta_{w}^{P}}{C_{W}^{P}(x)}=(1+\beta)(1-\gamma q) q \frac{\theta_{w}^{T}}{\bar{A}}
$$

which can be rearranged as

$$
C_{W}^{P}(x) \equiv(1-q) w(x)-q\left[\frac{1-\phi}{1+\delta} x+\frac{\phi}{1+r} B(x)\right]-\frac{r}{1+r} H(x)=\frac{\tilde{\gamma}}{\rho_{w}} \frac{\bar{A}}{1+\beta} .
$$

3. The political optimality condition for public-sector pensions. Since $\partial U_{t}^{T} / \partial B_{t+1}$ includes the indirect effect of $B_{t+1}$ through $H_{t+1}$,

$$
\begin{aligned}
& \gamma q \theta_{B}^{P}\left[\left(1+\frac{\partial H_{t+1}}{\partial B_{t+1}}\right) \frac{\beta}{C_{R}^{P}(x)}-\frac{\phi q}{1+r} \frac{1}{C_{W}^{P}(x)}\right]= \\
&(1-\gamma q) \frac{1+\beta}{1+r}\left(\phi q-\frac{\partial H_{t+1}}{\partial B_{t+1}}\right) \frac{\theta_{B}^{T}}{\bar{A}}
\end{aligned}
$$

which can be rearranged, plugging in the preceding equilibrium condition, as

$$
\begin{aligned}
C_{R}^{P}(x) \equiv B(x)+H(B(x))- & H(x)-R= \\
& \frac{\tilde{\gamma} q\left[1+H^{\prime}(B(x))\right]}{\rho_{w} \phi q^{2}+\rho_{B}(1-q)\left[\phi q-H^{\prime}(B(x))\right]} \frac{\beta(1+r) \bar{A}}{1+\beta} .
\end{aligned}
$$


An explicit solution for the dynamic equilibrium can be obtained because our assumptions ensure that the three equilibrium functions are all linear in inherited pension obligations.

Proposition 1 In equilibrium, house prices are a function

$$
H(x)=H+h(B-x),
$$

public-sector pension promises a function

$$
B(x)=\frac{B-h x}{1-h}
$$

and public employees' wage a function

$$
w(x)=w+\frac{h}{1-h} \frac{x-B}{1+r}
$$

of inherited pension obligations $x$.

The sensitivity of house prices to inherited pension obligations is a constant $h \in[0,(1-\phi)$ $q /(1+\delta)]$ that decreases with city growth $(\partial h / \partial \delta<0)$ and with pre-funding $(\partial h / \partial \phi<0)$ and increases with the share of public employees $(\partial h / \partial q>0)$ and the interest rate $(\partial h / \partial r>0)$.

For all $q<1 / 2$, equilibrium dynamics converge to a steady state with public-sector pensions

$$
B=R+\frac{\tilde{\gamma} q(1-h)}{\rho_{w} \phi q^{2}+\rho_{B}(1-q)(\phi q+h)} \frac{\beta(1+r) \bar{A}}{1+\beta},
$$

public-sector wages

$$
w=\frac{\tilde{\gamma}}{\rho_{w}} \frac{\bar{A}}{1+\beta}-\bar{A}+Y-\frac{R}{1+r},
$$

and house prices

$$
H=\frac{1+r}{r}\left\{Y-A^{T}-\frac{R}{1+r}-q\left[w+\left(\frac{\phi}{1+r}+\frac{1-\phi}{1+\delta}\right) B\right]\right\} .
$$

The structure of the equilibrium reflects the dynamic feedback between public-sector pensions and house prices. The immediate consequence of an increase $x$ in unfunded pension obligations $B_{t}$ is to require an increase in taxes $T_{t}$ by the amount $[(1-\phi) /(1+\delta)] q x$ of unfunded pension obligations per capita. This tax increase induces a one-to-one direct decrease in house prices $H_{t}$ by the amount. This decline, however, is counteracted by indirect effects, so the equilibrium fall in house prices dampened $(h<[(1-\phi) /(1+\delta)] q)$.

The starting point of the feedback loop is that a decline in house prices reduces public employees' housing costs. Political optimality requires an invariant consumption by public employees both while working $\left(C_{W}^{P}\right.$ is independent of $\left.x\right)$ and while retired $\left(C_{W}^{P}\right.$ is also independent of $x$ because $H(x)$ is linear). Since a decline in $H_{t}$ reduces one-to-one their mortgage repayment in old age, it requires a decline in pension promises $B_{t+1}$.

The decline in $B_{t+1}$ then triggers a proportional increase in $H_{t+1}$ because young buyers at $t+1$ expect lower taxes due to lower inherited pension obligations. Since public-sector retirees own houses in the city, the expected increase in their home equity $H_{t+1}$ requires a 
one-to-one further decrease in their pension $B_{t+1}$ to keep their retirement income constant. This multiplier effect implies that a rise $x$ in pension obligations $B_{t}$, which reduces current house prices $H_{t}$ by $h x$, also increases house price appreciation $\left(H_{t+1}-H_{t}\right)$ by $h x /(1-x)$, and reduces future pension promises by the same amount.

Both the present value of private-sector workers' lifetime disposable income $(\bar{A})$ and public-sector employees' net income while working $\left(C_{W}^{P}\right)$ are invariant, the former due to spatial equilibrium and the latter due to political optimality. Since all workers pay the same taxes, public-sector workers' gross wage $w_{t}$ needs to rise one-to-one with the present value of expected house appreciation (i.e., by $h x /[(1-h)(1+r)])$ to keep the two disposable incomes independent of $x$.

Finally, the equilibrium impact of inherited pension promises $B_{t}$ on house prices $H_{t}$ is the one that reconciles all the direct and indirect effects outlined above with spatial equilibrium: $h$ such that

$$
\frac{r}{1+r} h+\frac{1}{1+r} \frac{h}{1-h}=q\left(\frac{1-\phi}{1+\delta}+\frac{1}{1+r} \frac{h}{1-h}-\frac{\phi}{1+r} \frac{h}{1-h}\right) .
$$

The left-hand side captures the benefits accruing to period- $t$ residents through the housing market. The first term reflects lower house prices $H_{t}$, and thus a lower user cost of housing $r H_{t} /(1+r)$. The second term is the present value of higher future house price appreciation $\left(H_{t+1}-H_{t}\right)$. The right-hand side captures the cost borne by period- $t$ taxpayers to finance the public sector, with a natural scaling by $q$. The first term is the direct effect of inheriting higher unfunded pension obligations $B_{t}$. The second term reflects the higher wages $w_{t}$ that are politically required to let public employees, too, defray higher taxes. The last and partially compensating term reflects the pre-funding of lower pensions $B_{t+1}$ for future public-sector retirees.

The effect of exogenous parameters on the link between inherited pension promises $B_{t}$ and house prices $H_{t}$ is intuitive. The sensitivity increases with the size of the public sector $(\partial h / \partial q>0)$ because a larger share of public employees makes any individual entitlement more costly in the aggregate. It declines with pre-funding $(\partial h / \partial \phi<0)$ because it reduces the fraction of any past promises that must be borne by current taxpayers. ${ }^{4}$ House prices are less responsive when city growth is faster $(\partial h / \partial \delta<0)$ because the same burden is spread over a larger number of taxpayers and houses. ${ }^{5}$ They are more responsive when the interest rate is higher $(\partial h / \partial r>0)$ because the effect of future house appreciation is then muted, in turn muting the response of wages and pension promises.

\subsection{Steady State}

Proposition 1 establishes that equilibrium dynamics converge to a steady state by dampened oscillations, since

$$
B_{t+1}-B=-\frac{h}{1-h}\left(B_{t}-B\right)
$$

\footnotetext{
${ }^{4}$ In the limit case when pensions are fully funded $(\phi=1)$ there is no dynamic link between the policy choices of each generation $(h=0)$, since each prepays entirely any promises it makes to its public employees.

${ }^{5}$ The limit case of no city growth $(\delta=0)$ features precisely offsetting indirect effects: current wages $w_{t}$ and future house prices $H_{t+1}$ rise, future pensions $B_{t+1}$ fall, but in equilibrium current house prices $H_{t}$ simply reflect the direct increase in $B_{t}(h=(1-\phi) q)$.
} 
with $h /(1-h) \in(0,1)$ for all $q<1 / 2$. The core results of our model are the comparative statics on steady-state values.

Proposition 2 In the steady state, public-sector pensions are increasing in the share of public employees living in the city $(\partial B / \partial \gamma>0)$ and in information asymmetries concerning both wages and pensions $\left(\partial B / \partial \rho_{w}<0\right.$ and $\left.\partial B / \partial \rho_{B}<0\right)$. They are decreasing in prefunding $(\partial B / \partial \phi<0)$; increasing in population growth $(\partial B / \partial \delta>0)$, in the reservation utility $(\partial B / \partial \bar{A}>0)$ and in the cost of housing in the retirement destination $(\partial B / \partial R>0)$; and independent of city productivity $(\partial B / \partial Y=0)$.

Consumption by public-sector retirees is independent of housing in the retirement destination $\left(\partial C_{R}^{P} / \partial R=0\right)$ but shares all other comparative statics with pensions.

Public-sector wages are increasing in the share of public employees living in the city $(\partial w / \partial \gamma>0)$ and in information asymmetry concerning wages ( $\left.\partial w / \partial \rho_{w}<0\right)$, but independent of information asymmetry concerning pensions $\left(\partial w / \partial \rho_{B}=0\right)$. They are increasing in city productivity $(\partial w / \partial Y>0)$ and decreasing in the cost of housing in the retirement destination $(\partial w / \partial R<0)$, while they are independent of pension pre-funding $(\partial w / \partial \phi=0)$ and of population growth $(\partial w / \partial \delta=0)$.

Consumption by public-sector workers while employed is increasing in the reservation utility $\left(\partial C_{W}^{P} / \partial \bar{A}>0\right)$, in the share of public employees living in the city $\left(\partial C_{W}^{P} / \partial \gamma>0\right)$ and in information asymmetry concerning wages $\left(\partial C_{W}^{P} / \partial \rho_{w}<0\right)$; it is independent of information asymmetry concerning pensions $\left(\partial C_{W}^{P} / \partial \rho_{B}=0\right)$, of city productivity $\left(\partial C_{W}^{P} / \partial Y=0\right)$ of the cost of housing in the retirement destination $\left(\partial C_{W}^{P} / \partial R=0\right)$, of pension pre-funding $\left(\partial C_{W}^{P} / \partial \phi=0\right)$ and of population growth $\left(\partial C_{W}^{P} / \partial \delta=0\right)$.

The first set of comparative statics for public employees' earnings reflects the three dimensions of their political power. Naturally, the greater the fraction of public-sector workers that vote in local elections the greater their clout over policy making: both their wages and their pensions then rise $(\partial w / \partial \gamma>0$ and $\partial B / \partial \gamma>0)$. Indeed, the political optimality conditions highlight that their consumption in both life stages is directly proportional to the index $\tilde{\gamma}$ of their voting participation, so their lifetime utility is log-linear in it $\left(\partial \log C_{W}^{P} / \partial \log \tilde{\gamma}=\partial \log C_{R}^{P} / \partial \log \tilde{\gamma}=1\right.$ and $\left.\partial U^{P} / \partial \log \tilde{\gamma}=1+\beta\right)$. In our model, public employees' wages and pensions tend to rise together as a consequence of the political power of public-sector unions, rather than exhibiting a negative comovement, as predicted by the theory of compensating differentials (Smith 1981).

Proposition 2 stresses that political power derives from superior knowledge of policy choices. Public employees' wages, and thus their consumption when young, reflect asymmetry in information about wage proposals $\left(\partial w / \partial \rho_{w}<0\right.$ and $\left.\partial C_{W}^{P} / \partial \rho_{w}<0\right)$. Their pensions, and thus their consumption during retirement, reflect both asymmetric information about pensions and asymmetric information about wages $\left(\partial B / \partial \rho_{B}<0\right.$ and $\partial C_{R}^{P} / \partial \rho_{B}<0$, but also $\partial B / \partial \rho_{w}<0$ and $\left.\partial C_{R}^{P} / \partial \rho_{w}<0\right)$. The latter effect is a consequence of the complementarity between the two types of compensation: if public employees expect higher wages, they are more aggressive in their pension demands because they know they can afford their share of pre-funding.

In terms of the primitive information structure described by lemma 2, all components of public-sector compensation rise with the information-managing power of public-sector trade 
unions $\left(\partial w / \partial \underline{\theta}_{U}>0\right.$ and $\left.\partial B / \partial \underline{\theta}_{U}>0\right)$ and fall with the availability of public information through news media $\left(\partial w / \partial \underline{\theta}_{L}<0\right.$ and $\left.\partial B / \partial \underline{\theta}_{L}<0\right)$. Producer interests can capture policy-making over the issues they most care about without bargaining with politicians or offering them campaign contributions, but merely by disseminating political information to their members, as Ponzetto (2011) finds for the case of trade policy. Freeman (1986) reviews the impact of public-sector unions on wages and benefits. In our model, when politicians know that their proposals for public-sector compensation are widely broadcast among unionized public employees but relatively less visible to taxpayers, they make generous offers to avoid alienating the constituency that is disproportionately mobilized by these proposals. Conversely, the more media coverage a policy issue receives, the more policy proposals reflect the general interests of taxpayers rather than those of knowledgeable insiders. Greater shrouding of pension promises constitutes a decrease in transparency, and as such it entails greater capture of policy-making by public-sector workers and a consequent increase in their pensions $(\partial B / \partial \pi<0)$. Since the transparency of wage policy is unaffected by changes in shrouding, neither is the politically optimal wage rate $(\partial w / \partial \pi=0)$.

The effect of pre-funding reflects an intuitive tendency towards deficit spending in a polity without intergenerational altruism. In our model, voters are never entirely oblivious to the future cost of a pay-as-you-go pension system. They have a stake in the local real-estate market, and they understand that high pension debt will weigh down the future value of their own house. However, in a growing city they also understand that part of the burden will be borne by the developers of new housing. The electorate doesn't internalize the fall in developers' profits, and thus it is willing to accrue generous unfunded pension liabilities. The more pre-funding is required, the less can taxpayers shift the cost of pension promises onto future developers. As a consequence, political opposition to public-sector pensions rises and their equilibrium level falls $(\partial B / \partial \phi<0)$, reducing public employees' consumption when retired $\left(\partial C_{R}^{P} / \partial \phi<0\right)$. The same logic implies that pensions rise with city growth $(\partial B / \partial \delta>0)$, so long as pensions are not fully funded $(\phi<1)$. Faster construction implies that a greater share of unfunded pension liabilities is financed by developers instead of existing homeowners.

The final set of comparative statics in proposition 2 concerns economic primitives. Higher reservation utility increases public employees' welfare through a straightforward income effect: wealthier taxpayers can afford to provide higher consumption to their civil servants. Indeed, political optimality requires a constant ratio of public- to private-sector employees' consumption in all life stages. Thus, public employees' consumption is proportional to taxpayers' reservation disposable income $\left(\partial \log C_{W}^{P} / \partial \log \bar{A}=\partial \log C_{R}^{P} / \partial \log \bar{A}=1\right)$. An increase in retirees' consumption coincides with an increase in the their pensions $(\partial B / \partial \bar{A}>0)$. Instead, the effect on wages is ambiguous, since public-sector workers' consumption already rises through a decline in house prices, as shown below. Private-sector income and the cost of housing in the retirement destination, instead, have no effect on any resident's net consumption $\left(\partial C_{W}^{P} / \partial Y=\partial C_{W}^{P} / \partial R=\partial C_{R}^{P} / \partial Y=\partial C_{R}^{P} / \partial R=0\right)$. Hence, increases in the retirement housing costs are reflected one to one in public-sector pensions $(\partial B / \partial R=1)$. Private-sector productivity is reflected one to one in public-sector wage $(\partial w / \partial Y=1)$, and so is the discounted value of retirement housing costs $(\partial w / \partial R=1 /(1+r))$ because both are identically reflected in the user cost of housing in the city. 
The connection between the underlying political and economic structure and housing prices is the subject of our next proposition.

Proposition 3 In the steady state, house prices are decreasing in the share of public employees living in the city $(\partial H / \partial \gamma<0)$, in information asymmetries concerning both wages and pensions $\left(\partial H / \partial \rho_{w}>0\right.$ and $\left.\partial H / \partial \rho_{B}>0\right)$, in the reservation utility $(\partial H / \partial \bar{A}<0)$ and in the cost of housing in the retirement destination $(\partial H / \partial R<0)$. They are increasing in pre-funding $(\partial H / \partial \phi>0)$ and in city productivity $(\partial H / \partial Y>0)$.

The effects of political power on public-sector compensation and housing prices are always opposite. The reason is that, in equilibrium, rents (or quasi-rents) are transferred to public employees from developers. At the stage of political competition, electoral considerations pit public-sector workers against taxpayers. The former vote for higher benefits, and the latter for lower taxes that would increase their lifetime consumption. Given rational expectations and spatial indifference, however, such an increase in consumption is inconsistent with equilibrium. The expectation of lower taxes due to lower public-sector compensation instead leads agents to bid up the price of houses in the city. Thus taxpayers are essentially running a proxy competition against public employees on behalf of developers. When fewer public-sector workers vote and their information advantage is lower, the eventual outcome is a rise in real-estate values $\left(\partial H / \partial \gamma<0, \partial H / \partial \rho_{w}>0\right.$, and $\left.\partial H / \partial \rho_{B}>0\right)$. This result is consistent with Gyourko and Tracy's (1989) empirical finding that public-sector unions earn rents for their workers, and these rents are negatively capitalized in local land values.

The same distributional logic is reflected in the positive impact of pre-funding on house values. If public-sector pensions are pre-funded, their equilibrium level is lower, implying lower taxes and higher housing prices. There is, however, an additional effect. A pre-funded system is more efficient than a pay-as-you-go system, since the former is financed at the market rate of return $r$, while the latter has an internal rate of return $\delta<r$. An increase in pre-funding thus reduces the steady-state cost of financing any given level of public pensions, yielding a further increase in housing prices. The overall effect would become ambiguous if the local economy had a growth rate above the interest rate. Leeds (1985) failed to find evidence of a negative impact of unfunded pension liabilities on local property values. The effect of the growth rate itself is ambiguous for the same reason. On the one had, faster population growth creates political support for higher pensions, which tend to depress house values. On the other hand, however, it increases the internal rate of return of the unfunded component of the pension system, which tends to boost house values.

Finally, the comparative statics on economic primitives follow directly from spatial indifference. If the reservation utility of living outside the city is higher, the cost of living in it must be lower, implying lower housing prices $(\partial H / \partial \bar{A}<0)$. If productivity in the city is higher, housing prices must be higher so that real incomes are not $(\partial H / \partial Y>0)$. Since we have treated the cost of retirement housing as an expenditure for city residents, but not included it separately in the outside option, its increase also makes living in the city when young less desirable, requiring a compensating fall in city house prices $(\partial H / \partial R<0)$. 


\subsection{Efficiency}

As propositions 2 and 3 have established, there are two key interest groups in this model,: the developer (or initial land owner) and public-sector workers. We consider two possible approaches to efficiency. The first and easier approach is to only consider the developer and public employees separately. If the public-sector workers dissipate their rents through initial competition to win the public-employment lottery, then developer profits would be the only measure of welfare. Alternatively, we can think of the result on developer profits as informing us about the institutions that the developer would choose if he had the ability to do so. Public employees' welfare informs us about the institutions that public-sector unions would choose if they were in control. Our second approach to measuring efficiency relies on comparing equilibrium outcomes to a counterfactual first best that maximizes public employees' utility subject to the constraint that developer profits are not lower than in equilibrium.

Steady-state welfare for public-sector workers equals

$$
U^{P}=\log C_{W}^{P}+\beta \log C_{R}^{P}=\log \left(w+\bar{A}-Y+\frac{R}{1+r}\right)+\beta \log (B-R) .
$$

The developer earns profits from the sale of the housing stock as it gradually enters the market. Normalizing initial city size to one, the developer sells houses valued $H_{0}$ in the first period, and $\delta(1+\delta)^{t-1} H_{t}$ in every subsequent period $t \geq 1$. The present value of his profits is

$$
\Pi=\frac{1}{1+\delta}\left[H_{0}+\delta \sum_{t=0}^{\infty}\left(\frac{1+\delta}{1+r}\right)^{t} H_{t}\right] .
$$

It would be indifferent to let the developer extract some of his initial profits through a tax that the city charter imposes on the first generation of residents. We can conveniently parametrize by $B_{0}$ an obligation to pay taxes $(1-\phi) q B_{0} /(1+\delta)$ to the developer in period zero. Any $B_{0} \leq B+H / h$ is consistent with positive house prices, and developer profits are

$$
\Pi=\frac{1}{1+\delta}\left[H_{0}+\delta \sum_{t=0}^{\infty}\left(\frac{1+\delta}{1+r}\right)^{t} H_{t}+(1-\phi) q B_{0}\right],
$$

The appeal of this formulation is that it nest as two special cases both the baseline in which the developer can sell real estate to all generations but cannot tax tax even the first one $\left(B_{0}\right)$, and the alternative in which public-sector pensions immediately jump to the steady state $\left(B_{0}=B\right)$. The value of $B_{0}$ is irrelevant from the developer's point of view: the present value of his profits depends only on steady-state values.

Proposition 4 The lifetime utility of public-sector workers is increasing in the share of public employees living in the city $\left(\partial U^{P} / \partial \gamma>0\right)$ and in information asymmetries concerning both wages and pensions $\left(\partial U^{P} / \partial \rho_{w}<0\right.$, and $\left.\partial U^{P} / \partial \rho_{B}<0\right)$. It is decreasing in prefunding $\left(\partial U^{P} / \partial \phi<0\right)$; increasing in population growth $\left(\partial U^{P} / \partial \delta>0\right)$ and in the reservation utility $\left(\partial U^{P} / \partial \bar{A}>0\right)$; independent of the cost of housing in the retirement destination $\left(\partial U^{P} / \partial R=0\right)$ and of city productivity $\left(\partial U^{P} / \partial Y=0\right)$. 
Given equilibrium dynamics, the present value of developer profits is

$$
\Pi=\frac{1+r}{r-\delta}\left[Y-\bar{A}-\frac{R}{1+r}-q\left(w+\frac{B}{1+r}\right)\right],
$$

which is decreasing in the share of public employees living in the city $(\partial \Pi / \partial \gamma<0)$, in information asymmetries concerning both wages and pensions $\left(\partial \Pi / \partial \rho_{w}>0\right.$ and $\left.\partial \Pi / \partial \rho_{B}>0\right)$, in the reservation utility $(\partial \Pi / \partial \bar{A}<0)$ and in the cost of housing in the retirement destination $(\partial \Pi / \partial R<0)$; and increasing in pre-funding $(\partial \Pi / \partial \phi>0)$ and in city productivity $(\partial \Pi / \partial Y>0)$.

The comparative statics for the steady-state welfare of public-sector workers follow immediately from the analysis of their equilibrium compensation in proposition 2. Public-sector unions would like as many of their members as possible to reside and vote in the city that employs them $\left(\partial U^{P} / \partial \gamma>0\right)$, so as to exert greater electoral clout. Moreover, public employees obtain higher equilibrium compensation whenever they are more informed about policy proposals than other taxpayers, so their lifetime utility rises monotonically with any information asymmetry $\left(\partial U^{P} / \partial \rho_{w}<0\right.$, and $\left.\partial U^{P} / \partial \rho_{B}<0\right)$. Therefore, unions wish to convey as much information as possible to their members $\left(\partial U^{P} / \underline{\theta}_{U}>0\right)$, while they prefer the news to be as uninformative as possible $\left(\partial U^{P} / \underline{\theta}_{L}<0\right)$ and pensions maximally shrouded $\left(\partial U^{P} / \pi<0\right)$. Public-sector unions also favor minimal pre-funding of public-sector pensions $\left(\partial U^{P} / \partial \phi<0\right)$ and the fastest feasible city growth $\left(\partial U^{P} / \partial \delta>0\right)$, because both makes taxpayers less keen on fighting pensions promises, and therefore ensure the most generous pension provision in the ensuing political equilibrium. Finally, public sector workers share one-to-one in the reservation utility $\left(\partial U^{P} / \partial \bar{U}=1\right)$.

Developers internalize exactly the cost of providing steady-state wages and pensions. Their dynamics and the degree of pre-funding are irrelevant as such, and matter only through their influence on political equilibrium. Despite this difference, the comparative statics are identical to those of housing prices in proposition 3. The condition $r>\delta$ is now necessary for the growing city to have a finite value. The effect of city growth has a new source of ambiguity. As growth accelerates, pensions increase, unambiguously increasing the burden of public-sector compensation. But as the growth of the housing stock speeds up, so does the growth rate of developer profits.

The institutional preferences of the initial developer are diametrically opposite to those of the public-sector union, which is its long-run political rival. The developer prefers as many employees as possible to be hired outside of the city, so they cannot vote in local elections $(\partial \Pi / \partial \gamma<0)$. He wants maximum pre-funding $(\partial \Pi / \partial \phi>0)$ to ensure that residents are keen proxy fighters in the political battle against public-sector workers. Minimal information asymmetries are optimal for the developer $\left(\partial \Pi / \partial \rho_{w}>0\right.$ and $\left.\partial \Pi / \partial \rho_{B}>0\right)$, who consequently would like unions to have minimal ability to inform their members $\left(\left(\partial \Pi / \partial \underline{\theta}_{U}<0\right)\right.$. Conversely, he wishes that the taxpayers who buy his homes were as informed as possible about public-sector compensation policies $\left(\partial \Pi / \underline{\theta}_{L}>0\right)$, and particularly desires maximum transparency of public-sector pensions (high $(\partial \Pi / \pi>0)$. Finally, the developer has an obvious preference for creating a highly productive city $(\partial \Pi / \partial Y>0)$ and attracting residents with poor outside opportunities $(\partial \Pi / \partial \bar{A}<0)$ and cheap housing options during retirement $(\partial \Pi / \partial R<0)$. 
Proposition 4 establishes that developer profits are linear in the cost of public-sector compensation $w+B /(1+r)$. Thus, our counterfactual measure of efficiency consists of comparing equilibrium outcomes with first-best outcomes that have the same cost but give public employees the optimal consumption profiles. Optimality is attained when consumption during retirement equals $\beta(1+r)$ times consumption during working life. In equilibrium, public-sector compensation has a time profile

$$
\Gamma \equiv \frac{C_{R}^{P}}{\beta(1+r) C_{W}^{P}},
$$

which is inefficiently backloaded when greater than one, the same condition as a binding borrowing constraint for public employees.

The equilibrium welfare of public-sector workers can be written

$$
U^{P}=\bar{U}+(1+\beta) \log \frac{\tilde{\gamma}}{\rho_{w}}+\beta \log \Gamma,
$$

while at the same cost the optimal compensation profile would yield first-best utility

$$
U^{*}=\bar{U}+(1+\beta) \log \frac{\tilde{\gamma}(1+\beta \Gamma)}{\rho_{w}(1+\beta)} .
$$

The extent to which political inefficiency is leading to welfare losses can be measured by the difference the two

$$
U^{*}-U^{P}=(1+\beta) \log (1+\beta \Gamma)-\beta \log \Gamma-(1+\beta) \log (1+\beta) .
$$

The ratio $\Gamma$ of public employees' equilibrium consumption when old to equilibrium consumption when young is a sufficient statistic for efficiency. The welfare loss $\left(U^{*}-U^{P}\right)$ is a function of $\Gamma$ alone, up to the exogenous preference parameter $\beta$, and it is single-peaked at the efficient level $\Gamma=1\left(\partial \Delta_{U} / \partial \Gamma \propto \Gamma-1\right)$. The following proposition shows our results for this second welfare criterion.

Proposition 5 In the political equilibrium, public-sector workers' consumption is inefficiently backloaded $(\Gamma>1)$. The degree of inefficiency is is decreasing in prefunding $(\partial \Gamma / \partial \phi<$ $0)$ and increasing in city growth $(\partial \Gamma / \partial \delta>0)$. It is independent of the share of public employees living in the city $(\partial \Gamma / \partial \gamma=0)$, of the reservation utility $(\partial \Gamma / \partial \bar{A}=0)$, of the cost of housing in the retirement destination $(\partial \Gamma / \partial R=0)$ and of city productivity $(\partial \Gamma / \partial Y=0)$. It depends on information asymmetry exclusively through the relative asymmetry of information about pensions compared to wages, and it is increasing in it $\left(\partial \Gamma / \partial\left(\rho_{B} / \rho_{w}\right)<0\right)$.

Throughout the equilibrium path, and a fortiori in the steady state, public-sector workers receive backloaded compensation. Their borrowing constraint is binding, and their equilibrium consumption suboptimally low while working and suboptimally high while retired. In the first best, instead, all workers smooth consumption to identical levels during the two stages of their life (for $\beta(1+r)=1$ ). Thus, public employees could be made better off at no cost to the developer of to the taxpayer if their total compensation were kept constant, 
but their pensions reduced and their wages increased. The political equilibrium is inefficient because it prevents this optimal readjustment, for two reasons.

First, the electorate fails to internalize the impact of current policy choices on future developer profits. Thus all voters prefer to reduce public employees' wages, which they pay in their entirety, and increase public pensions, accumulating unfunded liabilities that will partially be defrayed by future taxpayers, and ultimately reflected in lower prices for new construction. As prefunding declines and city growth speeds up, the temptation becomes sharper and inefficient pension deficits larger $(\partial \Gamma / \partial \delta>0$ and $\partial \Gamma / \partial \gamma=0)$.

The second source of inefficiency is the shrouded nature of pension promises. As Lemma 2 their relative opacity makes it easier for the public-sector trade union to give its members an informational edge concerning pensions than current salaries. Thus, public-sector pensions are more captured by public employees' than public-sector wages. Compensation is backloaded to shroud it and confuse taxpayers about its actual cost. As a consequence, inefficiency would remain even if pensions were required to be fully pre-funded. ${ }^{6}$

Proposition 5 highlights that inefficiency derives not merely from asymmetric information across voters, but crucially from differential asymmetry across voters and policies. The impact is precisely summarized by the relative asymmetry of information about pensions compared to wages. Lemma 2 then implies that inefficiency rises with shrouding $(\partial \Gamma / \partial \pi<$ $0)$, but also with the informativeness of either source $\left(\partial \Gamma / \partial \underline{\theta}_{L}>0\right.$ and $\left.\partial \Gamma / \partial \underline{\theta}_{U}>0\right)$. There is no guarantee that transparency, naively construed, should increase the efficiency of public-sector compensation policies. On the contrary, inefficiency rises if taxpayers receive new information, but the additional information is as skewed towards wages as their original knowledge (higher $\underline{\theta}_{L}$, constant $\pi$ ). Public employees do suffer a decline in their overall benefits, but they respond to the increased pressure by obtaining benefits that are ever more skewed towards shrouded entitlements. An increase in efficiency derives only from targeted transparency on the more opaque and distorted policy dimension (higher $\pi$ ).

The distinction between efficient and inefficient news coverage is precisely the point where developer profits and aggregate efficiency diverge. The developer aims at an across-theboard reduction in public employees' compensation. Consequently he appreciates, and would promote if possible, any disclosure, whether focused on pensions or wages $(\partial \Pi / \pi>0$ and $\left.\partial \Pi / \underline{\theta}_{L}>0\right)$. Instead, efficiency increases when pensions fall but wages rises, and thus when the former become more visible but the latter less $\left(\partial \Gamma / \partial \pi<0\right.$ but $\left.\partial \Gamma / \underline{\theta}_{L}>0\right)$. Despite this crucial discrepancy, developer profits are a somewhat better guide to overall efficiency than public employees' welfare. Developer incentives are always aligned with efficiency when it comes to prefunding $(\phi)$, shrouding $(\pi)$ and union power $\left(\underline{\theta}_{U}\right)$, and they need not be opposed in the case of city growth $(\delta)$. In all four cases the public-sector trade union unambiguously prefers an inefficient institutional environment. Only for the reduced disclosure of wages $\left(\underline{\theta}_{L}\right)$ do the union's preferences coincide with efficiency.

The comparison of propositions 4 and 5 finally highlights the presence of purely redistributive conflict, separate from inefficient political frictions. The share of public employees living in the city $(\gamma)$ and the reservation utility $(\bar{U})$ are key determinants of bargaining power, respectively political and economic. A rise in both weakens the developer, reducing his profits, and strengthens public employees, raising their welfare. None, however, has any

\footnotetext{
${ }^{6}$ Formally, if $\phi=1$, then $\Gamma=\left[q+(1-q) \rho_{B} / \rho_{w}\right]^{-1}>1$.
} 
effect on the backloading of compensation. This accords with intuition because we would expect bargaining power to shape the sharing of surplus without inefficiently dissipating it.

Although we have not yet turned to the topic of centralized pension bargaining, these results already allow us to understand one major way in which states regulate localities: prefunding requirements. As we discussed in Section 2, localities that participate in state systems are subject to state rules about prefunding. These rules may be relatively lax, because of high assumed returns, but they do represent some attempt to regulate localities' behavior. Pre-funding is also a policy choice that in many cases only came about during the 1980s.

Prefunding has no impact on wages or the consumption of public sector workers during their working life. Prefunding, however, reduces pension promises and the consumption of retired public-sector workers, causing a decline of their lifetime welfare. As a consequence, public-sector unions should typically favor laxer pre-funding rules, which are presumably achieved in reality by assuming higher growth rates. Union power may also explain why public-sector pensions have not followed private-sector systems in moving from definedbenefit to defined-contribution schemes (Poterba, Venti, and Wise 2007). Conversely, developer profits increase with prefunding because of the decrease in pensions. Fiscal discipline should therefore by the developers' mantra and they should push for tighter prefunding requirements. We think that these results do help make sense of the political divisions over prefunding requirements.

What does prefunding do to the overall efficiency of the system? As pre-funding increases, the ratio of public consumption when young to public consumption when old increases. This means that the gap between worker welfare, and worker welfare given the first best consumption profile has decreased. As such, pre-funding doesn't just redistribute from workers to land owners, it also increases the efficiency of the system. This is one reason why prefunding requirements may be so universal.

In the next section we turn to a broader discussion of centralized control over public-sector pensions.

\section{Decentralization and Control over Pensions}

The primary purpose of the model is to enable us to consider the issues raised in section 2, which highlighted the heterogeneity in local control over pensions. In our model, we assume that there are two primary differences between local and state pension setting. First, when pensions are set at the local level, only a fraction of public sector workers vote in each election because some of them live outside the locality. When pensions are set at the state level, then all public sector workers vote in the election. Second, we assume that there is a third source of information about pensions and wages when the process occurs at the state level. Statewide news media cover statewide public-policy issues, which increases the probability that voters know about both public sector workers and public sector wages.

Specifically, we assume that, in addition to the probability of being informed by local sources, and independent of the arrival of information from those sources, every individual has probability $\underline{\theta}_{S} \in(0,1)$ of being informed of statewide wage-policy proposals by statelevel media. As with all sources of information, pensions remain less visible, and the relative 
probability of information through statewide news is only $\pi \underline{\theta}_{S}$. This implies that with centralization the information probabilities for taxpayers become

$$
\theta_{w}^{T}=1-\left(1-\underline{\theta}_{L}\right)\left(1-\underline{\theta}_{S}\right) \text { and } \theta_{B}^{T}=1-\left(1-\pi \underline{\theta}_{L}\right)\left(1-\pi \underline{\theta}_{S}\right)
$$

while those for public-sector workers are

$$
\theta_{w}^{P}=1-\left(1-\underline{\theta}_{L}\right)\left(1-\underline{\theta}_{S}\right)\left(1-\underline{\theta}_{U}\right) \text { and } \theta_{B}^{P}=1-\left(1-\pi \underline{\theta}_{L}\right)\left(1-\pi \underline{\theta}_{S}\right)\left(1-\pi \underline{\theta}_{U}\right) .
$$

As in lemma 2, the distribution of information is summarized by the two measures of symmetry. Denote the indices under centralization by $\rho_{w}^{S}$ and $\rho_{B}^{S}$, and under decentralization by $\rho_{w}^{L}$ and $\rho_{B}^{L}$. The information structure then admits the following characterization.

Lemma 3 For any policy proposal, public-sector workers are more likely to informed than taxpayers. Their information advantage is greater for pensions than wages $\left(0<\rho_{B}^{S}<\right.$ $\left.\rho_{w}^{S}<1\right)$. Information asymmetry declines when either news source provides more information $\left(\partial \rho_{w}^{S} / \partial \underline{\theta}_{L}>0, \partial \rho_{B}^{S} / \partial \underline{\theta}_{L}>0, \partial \rho_{w}^{S} / \partial \underline{\theta}_{S}>0, \partial \rho_{B}^{S} / \partial \underline{\theta}_{S}>0\right)$ and increases when public-sector unions provide more information $\left(\partial \rho_{w}^{S} / \partial \underline{\theta}_{U}<0\right.$ and $\left.\partial \rho_{B}^{S} / \partial \underline{\theta}_{U}<0\right)$. When pensions are more shrouded, information about them is more asymmetric $\left(\partial \rho_{B}^{S} / \partial \pi>0\right)$. The relative asymmetry of information about pensions compared to wages is higher when pensions are more shrouded $\left(\partial\left(\rho_{B}^{S} / \rho_{w}^{S}\right) / \partial \pi>0\right)$ and when unions provide more information $\left(\partial\left(\rho_{B}^{S} / \rho_{w}^{S}\right) / \partial \underline{\theta}_{U}<0\right)$. It is non-monotonic in the information provided by each news source, with a global minimum at $\hat{\theta}_{L} \in(0,1]$ and respectively at $\hat{\theta}_{S} \in(0,1]$.

Centralization reduces information asymmetry on all issues $\left(\rho_{w}^{S}>\rho_{w}^{L}\right.$ and $\left.\rho_{B}^{S}>\rho_{B}^{L}\right)$. It reduces the relative asymmetry of information about pensions compared to wages if and only if local news are sufficiently informative: $\rho_{B}^{S} / \rho_{w}^{S}>\rho_{B}^{L} / \rho_{w}^{L}$ if and only if $\theta_{L}>\bar{\theta}_{L}$, for a threshold $\bar{\theta}_{L} \in\left(0, \max \left\{\underline{\theta}_{S}, \underline{\theta}_{U}\right\}\right)$.

This lemma first replicates for statewide information the same results that lemma 2 established for local information. The only difference concerns an increase in local news coverage $\underline{\theta}_{L}$. Under decentralization it always makes the two issues more asymmetric $\left(\partial\left(\rho_{B}^{L} / \rho_{w}^{L}\right) / \partial \underline{\theta}_{L}<\right.$ $0)$. Under centralization, its effect is ambiguous because taxpayers' relative information is no longer fixed at $\pi$. When they are informed by statewide news sources, an increase in information from local news has a greater impact on the less visible issue, by the usual intuition of diminishing returns to information. Hence, the effect on relative asymmetry flips, at least for lower levels of informativeness $\left(\partial\left(\rho_{B}^{S} / \rho_{w}^{S}\right) / \partial \underline{\theta}_{L}<0\right.$ for $\left.\underline{\theta}_{L}<\hat{\theta}_{L}\right)$.

The second part of lemma 3 provides a comparison of information asymmetries with centralized and decentralized policy-making. Diminishing returns, again, imply that the statewide news source is more relevant for taxpayers, who rely on new only, than for publicsector workers, who also receive information from the unions. Thus centralization reduces the knowledge advantage of public employees on all policy dimensions $\left(\rho_{w}^{S}>\rho_{w}^{L}\right.$ and $\left.\rho_{B}^{S}>\rho_{B}^{L}\right)$.

The final result reflects that the relative asymmetry in information about pensions and wages can be attenuated in two ways: by making taxpayers more informed about pensions, or by making taxpayers less informed about wages. In the limit as local news disappear $\left(\theta_{L} \rightarrow 0\right)$ decentralization induces complete capture of both policy dimensions by public employees $\left(\rho_{w} \simeq \rho_{B} \simeq 0\right)$. Relative asymmetry is then minimized. 
However, in the case we consider most realistic, local news are more informative $\left(\underline{\theta}_{L}>\bar{\theta}\right)$. The empirical findings of Gentzkow (2007) and Snyder and Strömberg (2010) suggest that local newspapers are the main source of information about state and local policy, which would imply $\underline{\theta}_{L}>\underline{\theta}_{S}$. Informative local news imply that decentralized government lets public employees capture pensions but not wage-setting. Then the relative asymmetry on the two issue declines with centralization, as well as the absolute asymmetry on each.

We first turn to the impact of centralization on public-sector compensation and housing prices

Proposition 6 Centralization reduces public employees' wages and first period consumption if and only if the share of public employees living in the city is above a critical value $\bar{\gamma}_{w}$. This threshold is increasing in the information provided by local news ( $\left.\partial \bar{\gamma}_{w} / \partial \underline{\theta}_{L}>0\right)$ and decreasing in the information provided by statewide news and public-sector unions $\left(\partial \bar{\gamma}_{w} / \partial \underline{\theta}_{S}<0\right.$ and $\left.\partial \bar{\gamma}_{w} / \partial \underline{\theta}_{U}<0\right)$. It is independent of all other variables.

Centralization reduces public employees' pensions and their consumption while retired if and only if the share of public employees living in the city is above a critical value $\bar{\gamma}_{B}$, decreasing in the information provided by statewide news $\left(\partial \bar{\gamma}_{B} / \partial \underline{\theta}_{S}<0\right)$. When local news are sufficiently informative $\left(\theta_{L}>\bar{\theta}_{L}\right)$, a reduction in public-sector pensions is more likely than one in public-sector wages $\left(\bar{\gamma}_{B}<\bar{\gamma}_{w}\right)$ and its likelihood decreases with city growth $\left(\partial \bar{\gamma}_{B} / \partial \delta>0\right)$ and with pre-funding $\left(\partial \bar{\gamma}_{B} / \partial \phi>0\right)$.

The impact on public employees' wages captures clearly the opposite pull of the two political consequences of centralization. On the one hand, centralization empowers publicsector workers by enabling all of them to vote for the politicians in charge of setting their salaries. On the other hand, centralization curbs the political power that public-sector unions derive from superior information, by increasing the news coverage of policy issues that reaches all taxpayers alike. The former effect dominates in cities with a low share of public workers in the electorate, and the latter in those whose employees are more likely to also be residents $\left(\gamma>\bar{\gamma}_{w}\right)$. Centralization is more likely to reduce public-sector wages when local news sources are weaker $\left(\bar{\gamma}_{w} / \partial \underline{\theta}_{L}>0\right)$ and statewide news sources stronger $\left(\partial \bar{\gamma}_{w} / \partial \underline{\theta}_{S}<0\right)$ because it then implies a greater increase in taxpayers' knowledge and thus in their power. It is also more likely to reduce wages when the union is stronger $\left(\partial \bar{\gamma}_{w} / \partial \underline{\theta}_{U}<0\right)$ and exerts greater control over local politics.

By the same mechanism, centralization reduces pensions in cities with enough public employees in their electorate $\left(\gamma>\bar{\gamma}_{B}\right)$, and this is more likely when centralization generates more public information $\left(\partial \bar{\gamma}_{B} / \partial \underline{\theta}_{S}<0\right)$. Indeed, in the regular case of informative local news $\left(\theta_{L}>\bar{\theta}_{L}\right)$, centralization reduces public-sector wages whenever it reduces public-sector pensions, but may reduce pensions alone $\left(\bar{\gamma}_{B}<\bar{\gamma}_{w}\right)$. This is intuitive because, as we saw in lemma 3, centralization then reduces information asymmetries concerning pensions more than those concerning wages.

The influence of city growth and pre-funding is somewhat subtler. In the equilibrium described by proposition 1, pension promises are constrained by two costs off the equilibrium path. The cost of prefunding through higher taxes is symmetrically perceived by private- and public-sector workers. The cost of unfunded liabilities through lower house appreciation is less relevant for public employees, who are liquidity constrained. By reducing relative asymmetry between voters, centralization makes the calculus of political optimality of pensions 
more responsive to their impact on future house appreciation and less to that on current taxes. Thus, it is more likely to reduce pensions when their off-equilibrium impact would be felt the most on house appreciation, namely when growth is moderate $\left(\partial \bar{\gamma}_{B} / \partial \delta>0\right)$ and pre-funding limited $\left(\partial \bar{\gamma}_{B} / \partial \phi>0\right)$.

Proposition 7 Centralization increases house prices if and only if the share of public employees living in the city is above a critical value $\bar{\gamma}_{H}$, decreasing in the information provided by statewide news $\left(\partial \bar{\gamma}_{H} / \partial \underline{\theta}_{S}<0\right)$. When local news are sufficiently informative $\left(\theta_{L}>\bar{\theta}_{L}\right)$, an increase in house prices is more likely than a decline in public-sector wages, but less likely than one in pensions $\left(\bar{\gamma}_{B}<\bar{\gamma}_{H}<\bar{\gamma}_{w}\right)$.

The effect of centralization on house prices follows the familiar pattern. The more informative statewide sources, the more likely a reduction in the political power of public-sector unions. Such a decrease, by reducing the government payroll, yields a corresponding increase in house prices. Given that house prices reflect both the cost of pensions and that of wages, it is intuitive that likelihood that centralization increases them should be intermediate between those of reducing each component of public employees' lifetime compensation.

In cities with a very high share of public-sector workers in the electorate $\left(\gamma>\bar{\gamma}_{w}\right)$, centralization reduces their political power across the board, so that both their wages and their pensions decline and house prices conversely rise. Yet, centralization need not be an unmitigated harm for public employees. It can yield a decrease in pensions, but at the same time an increase in wages. In fact, this pattern is consistent both with a decline in aggregate compensation and a rise in house prices $\left(\bar{\gamma}_{H}<\gamma<\bar{\gamma}_{w}\right)$, and with an increase in aggregate compensation and a fall in house prices, when fewer public employees are local residents $\left(\bar{\gamma}_{B}<\gamma<\bar{\gamma}_{H}\right)$

The possibility of a decline in public-sector pensions matched by an increase in publicsector wages immediately suggests efficiency benefits of centralization, in the light of proposition 5. We now turn to the impact of centralization on the welfare of public sector workers and developer profits. As before, we consider the value of the city to its developer in time zero as one element in social welfare. Public sector workers present the second element in total social welfare.

Proposition 8 Centralization reduces the lifetime utility of public-sector workers if and only if the share of public employees living in the city is above a critical value $\bar{\gamma}_{U}$, decreasing in the information provided by statewide news $\left(\partial \bar{\gamma}_{U} / \partial \underline{\theta}_{S}<0\right)$. When local news are sufficiently informative $\left(\theta_{L}>\bar{\theta}_{L}\right)$, a reduction in public employees' welfare pensions is more likely than one in public-sector wages, but less likely than one in house prices, and a fortiori than one in public-sector pensions $\left(\bar{\gamma}_{B}<\bar{\gamma}_{H}<\bar{\gamma}_{U}<\bar{\gamma}_{w}\right)$. Its likelihood decreases with city growth $\left(\partial \bar{\gamma}_{U} / \partial \delta>0\right)$ and with pre-funding $\left(\partial \bar{\gamma}_{U} / \partial \phi>0\right)$.

Centralization increases the present value of developer profits if and only if the share of public employees living in the city is above a critical value $\bar{\gamma}_{\Pi}$, decreasing in the information provided by statewide news $\left(\partial \bar{\gamma}_{\Pi} / \partial \underline{\theta}_{S}<0\right)$. When local news are sufficiently informative $\left(\theta_{L}>\bar{\theta}_{L}\right)$, an increase in public-sector pensions is more likely than a decline in public employees' welfare, and a fortiori than one in their wages. It is less likely than an increase in steady-state house prices, and a fortiori than a decrease in public-sector pensions $\left(\bar{\gamma}_{B}<\right.$ $\left.\bar{\gamma}_{H}<\bar{\gamma}_{\Pi}<\bar{\gamma}_{U}<\bar{\gamma}_{w}\right)$ 
Comparing the first part of the proposition with propositions 6 reveals that the qualitative effect of centralization on public-sector worker's welfare is the same as that on their wages. Identically, the comparison with proposition 7 shows that the effect of centralization on developer profits is qualitatively the same as its effect on steady-state house prices. Quantitatively, however, centralization can reduce public employees' pensions while instead increasing their lifetime welfare $\left(\bar{\gamma}_{B}<\gamma<\bar{\gamma}_{H}\right)$, through a more than compensating increase in wages. Conversely, an increase in developer profits is a stricter condition than an increase in housing prices $\left(\bar{\gamma}_{H}<\bar{\gamma}_{\Pi}\right)$. Centralization can reduce public-sector pensions enough to lift steady-state house values, and yet reduce total developer profits because of the inefficiency of pay-as-you-go pensions when the interest rate is above the growth rate. ${ }^{7}$

Proposition 8 attests to the distributive tension connected with the choice between centralization and decentralization. Developers (and taxpayers more generally) want centralization when they expect the reduction in information asymmetry dominates the increase in the fraction of public-sector workers voting in the district $\left(\gamma>\bar{\gamma}_{\Pi}\right)$. Public sector workers have the opposite preference, and support centralization when they believe that their greater voting numbers should dominate their reduced information advantage $\left(\gamma<\bar{\gamma}_{U}\right)$.

Yet the final result also highlights the scope for consensual efficiency gains. There is a non-empty interval $\left[\bar{\gamma}_{\Pi}, \bar{\gamma}_{U}\right]$ for which centralization is Pareto efficient. Public-sector pensions fall $\left(\gamma>\bar{\gamma}_{B}\right)$, house prices rise $\left(\gamma>\bar{\gamma}_{H}\right)$ and so do developer profits $\left(\gamma>\bar{\gamma}_{\Pi}\right)$. But public employee' wages also rise $\left(\tilde{\gamma}<\bar{\gamma}_{w}\right)$ and so does their lifetime utility $\left(\tilde{\gamma}<\bar{\gamma}_{U}\right)$. The decline in pensions is more than compensated by the increase in wages, since under local policy pensions are too high relative to wages. Intuitively, public employees are willingly trading off an inefficient source of asymmetric political power, privileged information, for an efficient symmetric one, participation in the election. This creates aggregate efficiency gains that under some parameter values can be shared among all parties involved, leading to Pareto efficiency.

A starker result is obtained when we measure efficiency by the welfare loss for publicsector workers compared to the first-best compensation profile that costs the same to the city developer.

Proposition 9 Centralization reduces inefficiency if and only if local news are sufficiently informative $\left(\underline{\theta}_{L}>\bar{\theta}_{L}\right)$. The threshold is always interior $\left(0<\bar{\theta}_{L}<\max \left\{\theta_{S}, \theta_{U}\right\}\right)$. It increases with the information conveyed by rival sources of information $\left(\partial \bar{\theta}_{L} / \partial \underline{\theta}_{S}>0\right.$ and $\left.\partial \bar{\theta}_{L} / \partial \underline{\theta}_{U}>0\right)$ and with the shrouding of public-sector pensions $\left(\partial \bar{\theta}_{L} / \partial \pi<0\right)$.

This results follows directly from lemma 3 given the equilibrium value of inefficient backloading $\left(\Gamma_{S}\right.$ or $\left.\Gamma_{L}\right)$, which is determined by the relative asymmetry of information about pensions compared to wages. In what we consider the regular case of sufficient local information, centralization is always efficient in the sense of yielding greater consumption smoothing for public-sector employees, although its effect on their welfare and on the public-sector payroll can change sign depending on electoral participation by public employees $(\gamma)$.

Nonetheless, the proposition can also be read as a cautionary note against relying on the notion that any increase in public information is always efficient. As proposition 5

\footnotetext{
${ }^{7}$ With full prefunding, or in the limit as $\delta \rightarrow r$, centralization increases developer profits if and only if it increases steady-state house prices: $\bar{\gamma}_{H}=\bar{\gamma}_{\Pi}$.
} 
emphasized, transparency is efficient if it reduces the shrouding of pensions, but not if it merely provides more information about wages. Proposition 9 shows that, if local media are the main source of political news $\left(\theta_{L}>\max \left\{\theta_{S}, \theta_{U}\right\}\right)$, then the efficiency of centralization is guaranteed. If instead local coverage is is dominated by other sources of information, centralization is efficient only if the difference between these sources is no too large, and if pensions are not too shrouded. Otherwise, the flatter public-sector compensation profile is obtained by local taxpayers who are uninformed about all policies, rather than by the statewide electorate, whose knowledge becomes more skewed as it rises above a negligible starting point.

Our model thus predicts that there are conditions under which centralization is efficient, and more restrictive conditions under which it is beneficial for both sides, private developers and public-sector unions. However, we do not know whether increased information or increased voting will be more powerful in the real world. We believe that the model has served to highlight the relevant parameters which will determine the impacts of centralization. We hope that this will inform future empirical work.

At this point, we turn to a discussion of the history of centralized control over pensions in Massachusetts, California, Ohio and Pennsylvania. We discuss the first two states at length, discussing their history and current systems. We then compare Ohio and Pennsylvania today.

\section{Local Pension Funds and Consolidated State Con- trol: Case Studies}

After the Civil War, localities began, in a small way, offering pensions to policemen, a natural extension of the pensions already being given to war veterans. After those modest beginnings, there were two great waves of state and local public pension expansions within the United States. The first wave occurred during the Progressive Era, when states set up pension schemes for teachers and other employees, and sometimes tried to regularize the pre-existing local systems that focused on police and firemen. Between 1911 and 1915 alone, 23 states enacted legislation pertaining to teachers' pensions (Graebner 1978).

Perhaps the most important reason why Progressives supported teachers' pensions is that they were seen as tools for professionalizing teaching and improving educational efficiency. Pensions, like any form of added compensation, might attract better teachers, but pensions seemed to have particular advantages too. Pensions were thought to induce elderly teachers to retire, and some believed that elderly teachers were less capable, particularly if they had failed to embrace newer methods. Pensions were also seen as a tool for ensuring that teaching became a lifelong profession, rather than a temporary job for young adults. While today we might think that temporary teaching stints, like those offered by Teach for America, are an attractive option, progressives worried about the inexperience of the young. Some progressives even apparently thought that pensions might reverse the trend towards more female teachers, and some saw male teachers as a critical element in professionalizing teaching.

Progressives were also attuned to European trends, and many European nations, including Russia and Italy, already had teachers' pensions. Many, but not all, progressive also favored social insurance, and public pensions can be seen as a form of poverty reduction. Fi- 
nally, public sector workers, especially teachers, were often overrepresented in the progressive movement, so that supporting public pensions was also sensible self-interest for many.

America's enthusiasm for social legislation dimmed after 1921, but then awoke anew during the 1930s. Dr. Francis Townsend helped lead a national movement for universal old-age pensions that culminated in the Social Security Act. But state and local publicsector workers were specifically excluded from the Social Security Act, since the Federal Government did not believe that it had the ability to compel states and localities to join the system. This led a number of states, including California, to greatly expand public pensions during the New Deal era.

This trend did not abate during World War II, as several states expanded their pension systems during the war. One explanation for the war-time expansion is that pensions are deferred compensation that provided a means of increasing effective salaries without falling afoul of national wage and price controls.

Since cities and towns often lacked the independent authority to establish their own pension systems, state governments were typically involved from the start, even if their role was limited to merely allowing localities to establish their own pensions, either on a cityby-city basis, or with state-wide legislation that provided a template for everyone. In some cases, especially with teachers' pensions, state-wide systems emerged out of almost nothing. In other cases, states first allowed localities to innovate and then tried to enforce some uniformity either by imposing rules on local pensions, like Massachusetts, or by completely consolidating the myriad local plans into a state-wide system, like Ohio. Of course, some areas, like Pennsylvania, continue to have a large number of fairly independent local pension plans.

In this section, we will begin with a fairly detailed case study of Massachusetts, which is notable in that it is an early innovator and that it has produced a somewhat intermediate system. We will then compare Massachusetts with California, another often progressive state that took a different path regarding local pensions. We will then, far more briefly, compare Pennsylvania and Ohio, two neighboring states with completely different approaches towards local pensions.

\subsection{Local Pensions in Massachusetts}

In 1911, Massachusetts began its pioneering state pension system, but this was hardly the beginning of public pensions in the Commonwealth. Soldiers in the Revolutionary and Civil Wars had received pensions, and the annual budget set aside a small amount for charitable pensions that were unrelated to public service. According to a 1914 Report of the Commission on Pensions ${ }^{8}$, non-military public pensions in Massachusetts really began in 1870, with a modest system for Boston police, which followed, by 13 years, New York City's pioneering police pension plan.

Municipal courts paid witness fees to policemen, and after 1870 those fees were deposited into a charitable fund, to be used for "the relief of persons who have received an honorable discharge from the police department, by reason of sickness, age or other disability, and who in consequence thereof are in necessitous circumstances: and also to the relief of widows

\footnotetext{
${ }^{8} \mathrm{http}: / /$ archive.org/stream/pensions00massrich\#page/126
} 
and orphans in necessitous circumstances of police officers who died while in the service of the city." While home rule was limited in Massachusetts, this fund didn't require any incremental city spending and was enacted without any enabling legislation by the state. It almost seems as if the city was just trying to do something reasonable with the flow of witness fee payments

The Massachusetts state legislation enacted its first real pension eight years later, when it created a true pension system for Boston police. According to that act, policemen who were disabled in the line of duty or who retired after 15 years could receive up to one-third of their active pay. The funds for these pensions would either come from the charitable fund established in 1870 or, if necessary, "any sums which may be specially appropriated therefor by the city council." Even though the pension system was entirely city specific, and paid for entirely by the city's own sources, the state established the pension's existence and the upper limit to its generosity.

This act set the pattern for the rest of the 19th century. In 1887, the state legislature made Boston's police pensions more generous, by increasing the pension payout to those policemen disabled in the line of duty to one-half of their salaries. In 1892, the state legislature made the city council (and general tax revenues) the funding source for police pensions. In 1880, the state created a pension system for Boston's firemen, essentially with the same terms that were given to police seven years later.

These early steps illustrate the perpetually hybrid nature of local pensions in Massachusetts. The systems were entirely Boston-specific, but they still had state oversight, and the state seems to have acted mainly to create an upper limit on pension generosity. These early systems were pay-as-you-go, apart from the fund created with witness fees, so there was relatively little scope for issues relating to the funding and financing of pension systems.

But gradually, the state expanded its pension policies beyond Boston. In 1890, the state established a statewide relief association for firemen, funded by taxes on fire insurance companies, that would deliver assistance to firemen state-wide on an ad hoc basis. In 1892, the state legislature began passing enabling legislation that empowered, but did not require, other cities with over 75,000 inhabitants to create pension systems similar to those already existing in Boston. In 1900, cities outside of Boston were similarly allowed to pension firemen.

In 1901, pensions for disabled policemen were enabled in every city and town throughout the state. The language of the act is a bit more forceful: "In every city and town, the board or official having authority to make appointments to the police department shall retire from further service therein any member who shall be certified by the city or town physician and by two other physicians to be permanently incapacitated, either mentally or physically, by injuries sustained in the actual performance of duty in the department; and the member so retired shall receive annually one half the compensation received by him at the time of his retirement." While this sounds like a pension mandate, the act only takes effect if it is approved by the city council (in the case of a city) or town vote (in the case of the town), essentially maintaining abundant local control. Yet, while the local governments had the power not to enact a police pension scheme, they had to follow the state's rules if they did want a pension system. Again, there was no provision for funding future pension obligations.

In 1904, towns were also allowed to pension both police and firemen who retired without disability. There was also a perpetual stream of individual pensions approved by the state legislature for individuals who did not fit exactly into the existing legislation. 
To a certain extent, the pensioning of police and firemen was a natural extension of the pensioning of soldiers. These professions carried considerable risk, and it seemed just to provide some insurance against the dangers faced while serving the state. The move from disability-based pensions to pensions based on length of service was a bit of a leap in all three cases. But Civil War veterans represented a large and well organized voting bloc able to extract considerable generosity from the government, and if the war veterans got old-age pensions, then it may have seemed natural to grant similar pensions to the veterans of local fires and violence.

The next great leap occurred in 1900, when the state established a retirement fund for Boston's public school teachers. While the police and military pensions were funded by general revenues, the retirement fund for Boston teachers was to be funded primarily by the teachers' own payments: three dollars every other month. This appears to be the first major contributory system in the state. Teachers were expected to retire after 30 years, and to have paid 540 dollars into the system, but there was a provision enabling the fund's board of trustees to waive this requirement in case of need. The pension payments went unspecified; they were to be determined by the board of trustees "as the fund will allow." The law specified the rules selecting the trustees, which must include both male and female teachers, and the trustees determined the investment policies of the fund.

But this system didn't last long. By 1908, the state legislature moved Boston's teachers to a fixed pension, of $\$ 180$ per year ( $\$ 4,320$ in present-day dollars), for teachers retiring after 30 years. The pension was to be funded through the contributory retirement fund, and through an increased property tax on the city. In the same year, the legislature enabled other cities and towns to establish their own pension systems, funded with general revenues on a pay-as-you-go-basis, which paid up to one-half the teachers' final salary.

In 1910, the state passed enabling legislation for all cities and towns to create almost modern pension systems for all of their employees. They were allowed to make the systems partially contributory (payments could range from one to five percent of earnings) and to pay for residual costs out of general tax revenues. In this case, the act specified a minimum payment (200 dollars per year), rather than limiting the maximum pension. The 1914 state report on pensions noted that no city or town had actually made use of this legislation.

While these systems may not have appealed to local governments, the 1910 act provided a rough template for Massachusetts' 1911 system for state employees. The State Retirement Board would establish an annual contribution rate, between one and five percent, which could differ by class of workers. Those contributions would then be turned into an annuity upon retirement, which would be matched with an equally sized annuity, funded with general state revenues on a pay-as-you-go basis. In 1911, Boston also created a pension system for ordinary laborers.

In 1913, the State took the even bolder step of creating a parallel system for Massachusetts teachers. Again, employees were required to make contributions to an annuity fund, ranging from three to seven percent of their income (the Board would later choose a five percent rate). Again, these payments would be used at retirement to fund an annuity, and the State would match the annuity payments out of general revenues. ${ }^{9}$ The somewhat remarkable

\footnotetext{
${ }^{9}$ As early as 1920, the contributory portion of the plan was being lauded for its "scientific" soundness, while the state's portion was seen as posing a risky unfunded liability.
} 
aspect of this legislation is that the state took upon itself to pay for one-half of the expense of pensions for one particular class of local employees.

In the context of the model, the decision to enact a pension system seems somewhat distinct from the decision about whether to increase pension benefits in an existing system. Smaller localities may have shied away from enacting their own pension systems precisely because they suspected that it would be difficult to monitor. At the state level, there was more chance of electoral oversight. It is also possible that there were enough teachers living outside of smaller communities to weaken their political clout at lower levels of government.

While teachers had become entirely subsumed into the state system in 1913, cities and towns either adopted their own systems, following the terms of the 1911 law, or did nothing. In 1936, amidst the national groundswell for all-old pensions led by Francis Townsend that led to the 1935 Social Security Act, Massachusetts again tried to prod localities towards pension systems. In this case, the state legislature authorized contributory systems, which public workers would contribute five percent of their salary to. Those contributions would buy an annuity and the local government would match the annuity. Whereas the teachers' system was a major transfer from state to local government, this system was just empowering localities to form and fund their own systems.

The modern system was essentially put together in 1945. Again, the legislation was optional, but it was quite clearly intended to create a "uniform" pension system. Again, there were annual contributions of five percent, but the pension payment was no longer based on the value of an annuity that could be purchased based on those contributions. Instead, workers were guaranteed a fixed formula typically found by multiplying years of service times two percent times an average of several years' peak earnings. In a sense, the formula had moved away from "scientific" funding practices, towards a system that guaranteed a fixed pension allowance.

The pension system was still voluntary, yet since 1945 the system has come to cover the state. One reason for the law's success was surely that the law mandated that this option had to be placed on the ballot in every subsequent state election until every city or town accepted it. We do not have good records as to when individual towns opted in - in at least one case, the official town records claim to have lost the date. It is clear that this law created the core Massachusetts system where salaries continue to be negotiated at a local level, but the rules regarding pensions are set at the state level.

The basic contours of the 1945 system are still in place. Moreover, Massachusetts is still one of the states that has opted against joining Social Security, which means that public pensions play a more dominant rule determining the earnings for retired employees. There have been, however, adjustments to both the pension payout formula and employee contributions. The pension formula is now considerably more complex and it depends on the class of worker. The maximum pension payout now multiplies years of service by 2.5 percent, instead of two percent, but it can be lower for workers who retire somewhat earlier.

More significantly, the pension system has had to deal with repeated funding crises, supporting the model's core assumption that the costs of a pension system may be difficult to forecast. Increased life expectancies were one reason for the funding shortfalls, but given longterm secular rises in life expectancy, some of that change should have even been foreseeable. Some of the unplanned costs of pensions were met with increases to employee contributions. The core pension contribution rate increased from five to seven percent in 1975, eight percent 
in 1984 and nine percent in 1996.

But other costs were met by increasing the level of public contributions, and particularly by switching from a pay-as-you-go to a more fully funded pension system. During the middle 1980s, the Dukakis administration, and especially the Secretary of Administration and Finance, Frank Keefe, focused on pension reform, both for the state and for localities. In 1987, the legislature finally passed a plan that represented a watershed for pension reform in Massachusetts. Not only did the state have to contribute to a Pension Reserve Fund, but the state would also mandate local contributions to pay down their unfunded pension liability. While membership in this system was technically optional, localities ultimately joined. The result was that localities were told how much to set aside for their pension liabilities.

With that act, the modern system was fully put in place. While the terms of these pension funds have been set centrally since 1945, Massachusetts continues to have local pension funds that in many cases manage their own portfolios. Investing with the state's investment system is optional, unless the local board earns significantly lower returns for an extended period of time. Local boards do typically earn less, although these lower returns may also represent a more risk averse investment strategy.

The degree of underfunding differs from town to town. Some areas, like wealthy Wellesley and Lexington, have funding ratios over 85 percent. Other, poorer areas, like Lawrence and New Bedford, have funding ratios that are closer to 40 percent. Moreover, these funding ratios reflect aggressive estimates of future returns $(8.25 \%$ ), which may well be at odds with reality. State law mandates that they set aside funds to close the funding gap by 2040, but it would not be surprising if this gap were pushed out further if returns continue to fall below 8.25 percent, or if localities raise insufficient revenues.

The Massachusetts system is essentially a generous statewide system. The state takeover in 1945 did eliminate vagaries in local systems, but it also produced a very generous pension system that only began pre-funding its requirements on a large scale forty years after its initiation. The Boston experience suggests that state control has probably restricted pensions in larger cities, which have strong local unions, but quite possibly increased pensions in places where local public workers are unlikely to live (including Lexington and Wellesley).

\subsection{A Shorter Sketch of California}

Like Massachusetts, California was a progressive state that moved into pensions early. Indeed, in the case of teachers' pensions, California preceded Massachusetts. In 1895, California passed an "act to create and administer a Public School Teachers' Annuity and Retirement Fund in the several counties, and cities and counties of the state." The act entitled teachers who had served twenty-five years or more to a retirement income of $\$ 50$ per month, but provided only modest means of funding this outlay.

Teachers who retired shortly after the law was enacted would have to pay a one-time fee of $\$ 600$, representing only one year's cost of the program. The other source of revenues was a one-percent levy on teachers' wages, which again seems insufficient to pay for the pension program. Perhaps recognizing the obvious insolvency of the plan, the legislature directed local treasurers to pay retirees in the form of warrants, paying five percent interest, which would be "paid in order of registration."

This act was ambitious but it seemed to ensure ongoing fiscal uncertainty for retiring 
teachers. Eighteen years later, the state repealed the 1895 act and enacted the current teachers' retirement system, in exactly the same year as Massachusetts' plan. The plan offered teachers who had served for thirty years a retirement income of $\$ 500$ per year, making it considerably less generous than the 1895 plan, since the $\$ 600$ offered by that plan in 1895 would have been almost $\$ 720$ in 1913 . But teachers were still required only to contribute a relative nominal dollar per month.

This plan, however, did have a rather serious source of added funding. The state law directed that five percent of all inheritance and transfer taxes would be given to the teachers' retirement fund and suggested that the state legislature would make further contributions, as needed. There may have been an extremely tenuous link between inheritance taxes and teachers, but California has established a feasible system for teacher pensions. Like Massachusetts, California had completely detached teachers' pensions from local control.

The 1913 law is seen as the founding of the current California teachers' retirement system (CalSTRS) that continues to this day. Over time, there were considerable changes to the structure of the system. In 1935 member contributions were raised to $\$ 24$ per year, and in 1944 payments became proportional to teacher salaries.

In 1944 the state also dropped the link to the inheritance tax and instead adopted a pay-as-you-go system, creating the possibility for more shrouding of the costs of teacher compensation. In 1956 the state switched from a fixed annual benefit for retirees to a benefit that scaled up with final-year salary. In 1972 the state saw that annual appropriations would have to rise substantially under a pay-as-you go system and began pre-funding its obligations to retired teachers. Since then the core system has remained unchanged, but California has faced the continuing challenge of meeting its funding requirements.

While the California teachers' system has essentially been a uniform state-wide system since 1913, pension for other local employees are far more diverse. In these other areas of local pensions, California began with more centralization than Massachusetts, but ended up with more local heterogeneity, perhaps reflecting the far greater heterogeneity of a much larger state. California had police pensions before teachers' pension, just like Massachusetts, but while Massachusetts began with a Boston-specific rule, and gradually invited other cities and towns to create their own police pension funds, California created state-wide rules at one fell swoop. In 1889, the state legislature passed "an act to create a police relief, health, and life insurance, and pension fund in the several counties, cities, and counties, cities and towns of this state." There had been earlier ad hoc life and health insurance funds, but these were now merged into these new, centrally regulated police benefit funds.

Policemen would contribute two dollars per month into the fund, but this would be supplemented by a remarkable diverse list of other funding sources. The policemen's retirement fund was also the beneficiary of, among other things, one-half of fees for dog licenses, all of the receipts from selling unclaimed property, and the fines for carrying concealed weapons. Policemen were then to receive half pay upon retirement at age sixty, if they had served for at least twenty years. All policemen paid the same amount to the system, but the benefit scaled up with the policeman's final salary, making the system somewhat regressive.

But while California began with homogeneity, that homogeneity soon broke down and the state did little to restrict local innovation. For example, the charter of San Francisco altered its police pension system (raising the retirement age to 65 among other changes), and this was held to be valid by the courts. The charter itself was not exactly a unilateral 
act by the city; it had the approval of the state legislature as well.

Home rule became much stronger in California than in Massachusetts, and that tradition may partially explain the greater heterogeneity of pension plans in California. Massachusetts has a form of home rule, but it precludes, among other things, any ability of localities to raise revenues or borrow without the approval of the state legislature. California has given localities wide latitude, even to rewrite their charters. Since 1974, cities can rewrite their charters without even the approval of the state legislature.

While there is considerable variation in modern pension plans across jurisdictions, the state has typically enabled that variation to occur with limits. The Californian system for police and other local employees, other than teachers, is regulated diversity. The state legislature sets a template and localities have room to design their specific plans within those limits, enabling some localities, like Stockton, to deliver particularly generous pension plans.

This diversity doesn't primarily reflect the gradual creation of widely different structures, which was basically the pre-1945 situation in Massachusetts. Instead, the California enacted state wide plans and then allowed moves towards regulated local control. In 1919, the State enacted a County Employees law that designed a pension system that counties could voluntarily adopt, if four-fifths of the County Board of Supervisors voted to enact the system.

The Supervisors were faced with a take-it-or-leave-it offer narrowly prescribing a particular pension system that involved four dollar monthly deductions from employees' paychecks. The county also had to match those contributions if the employee became disabled or served for ten years. The contributions would earn interest and then be annuitized at the time of retirement, which guaranteed that the system costs couldn't spiral out of control. As is the case of many Progressive-era reforms, good government concerns precluded incurring vast future obligations. In the 1919 Act, counties' only pension costs that were not accrued at the time the work was done related to workers who had less than ten years in the system. Matching contributions were not made until the worker served for ten years, creating the need to transfer a lump sum fund at that point, equal to the workers' past contributions, into the system.

While this proposal does seem to have been fiscally sound, it did not seem to attract much interest. The homogeneity of rules may have been one deterrent, although the four-fifths vote surely was another. In 1937, California enacted the County Employees Retirement Act, now known as the "37 Act", which has enabled the creation of 20 distinct county retirement plans, still in place today.

The 37 Act now has a wide range of county-specific rules, all set down in state law. In 1939, the state legislature enabled smaller jurisdictions, including counties, to join the state employees retirement system (SERS, now CalPERS) that is in place today. The system involves a number of generally applicable rules, but there is plenty of scope for negotiation with CalPERS about the generosity of the pension plan. CalPERS is best seen as the manager of local plans, which have autonomy only within a band of possible contribution rates and overall generosity. CalPERS typically requires local governments to make appropriate contributions, but localities under financial pressure may choose to limit contributions.

One possible explanation for why the systems in California and Massachusetts have very different degrees of central control, yet produce results that are not wildly different, is that Massachusetts local governments (outside of Boston) are often quite small, while California has number of very large county governments and cities. It is implausible to imagine that 
there would be large media attention on the idiosyncratic vagaries of pension systems in small towns, like Concord or Revere in Massachusetts, while there is at least some attention being paid to large county systems in California.

The overall California system means that local governments today negotiate with local unions over the generosity of the pension systems, as opposed to Massachusetts, where outside of Boston they do not. On average, the Massachusetts system pays $\$ 21,500$ in benefits per active benefit recipient. The California system pays $\$ 36,000$ per active benefit recipient. This does represent a striking difference, especially since overall earnings are similar: median household income was actually higher in Massachusetts in 2010 than in California.

These overall payment levels can combine a number of different local features, so it is easier to compare the actual terms of Massachusetts and at least one large local system in California. For a worker who retires at 65 with 40 years of service, the Massachusetts system provides a maximum payment of 80 percent of pay (averaged over the last three years of service). Cost of living adjustments are optional for the community, and in recent years, the employee will have to contribute nine percent of earnings to receive this pension.

In Los Angeles, there are contributory and non-contributory options. The non-contributory option (Plan D) will also delivery 80 percent of top pay to employees who retire after 45 years of service at the age of 65 . The employee will have to pay if he wants COLA adjustments, so if anything this system is less generous in retirement than the Massachusetts local system, but it doesn't require any employee contribution, which is a very significant difference. If the Los Angeles employee wants to contribute, then his contributions are still typically less than in Massachusetts. The contribution is only six percent if the employee begins work at age 25, and it only passes nine percent if the employee starts at 45 . Moreover, the maximum payment is 100 percent of pay, which is reached after 42 years of service. Altogether, the plan seems substantially more generous than the Massachusetts system, and this is true for a large number of local California plans.

This fact seems to support the view that local control can lead to more unsupervised pension expenditures. Indeed, the California system may be the worst of both worlds. The jurisdictions are large enough so that workers are likely to live and vote within their particular county, but not large enough to have a dedicated media focused on delivering hard analysis of pension deals. As such, the model would predict that this system would seem to generate particularly generous pensions, as it does.

An added downside of California's heterogeneity is that poorly managed governments have the capacity to take on particularly onerous pension obligations. Massachusetts does have communities that have more or less fully funded pension programs, but these differences reflect differences in community fiscal affairs, not differences in the generosity of their pension obligations. In California, communities like Stockton face pension-related fiscal distress both because of failure to fund and because of particularly generous plans. As such, even if the average pension systems were similar, which they aren't, California has more variance, and that may be particularly harmful if distressed communities, like Stockton, cause particular problems.

There is an added difference between California and Massachusetts that makes pension obligation far more difficult to change in California: the so-called "California Rule." Typically, employers have a legal obligation to respect pension that have been accrued, but they 
can change the pensions associated with future years of work. However, in 1947, the California Supreme Court decided that the City of Long Beach could not unilaterally end its pension system without compensating workers, even when those workers' pensions have not yet vested. The original case was brought by a worker who was 32 days short of the 20 year vesting period (Monahan 2012).

In a subsequent 1955 case, the court ruled that no part of a pension system may be eliminated for existing workers, except if any reduction in benefits is offset by a comparable advantage. This ruling essentially means that the full pension schedule is a legally binding promise to workers on their first day of work, which makes reform particularly difficult, at least outside of bankruptcy. Massachusetts pointedly declined to follow California along this path, meaning that pensions can be restructured, as they have been, with increasing worker contribution rates for existing workers.

\subsection{Ohio and Pennsylvania}

While California and Massachusetts seem to point towards a positive connection between decentralization and more generous patterns, we cannot claim that this represents a universal relationship, which suggests that in some cases added union power at the state level may overwhelm the advantages of more media attention through centralization. The neighboring states of Pennsylvania and Ohio are similar in many ways, but they are polar opposites in the degree of local control over pensions. Pennsylvania is the extreme of local heterogeneity and control, with over 1,400 distinct, locally administered pension plans. Ohio epitomizes centralization, with a single state-wide system that covers all local employees, outside of Cincinnati. That state-wide system was put in place in 1967 to address underfunding problems at the local level.

Despite the proliferation of Pennsylvania plans, the average generosity of these plans is not particularly high. The average benefit per beneficiary is under $\$ 21,000$ in 2010. Of course, many Pennsylvania jurisdictions are considerably smaller than those in California, and this may mean that workers live outside the area. Other possible explanations for why local control has led to generous systems in California, and not in much of Pennsylvania, is that Pennsylvania is poorer, and growing far less quickly.

To get an actual appreciation of terms, we looked at two Pennsylvania jurisdictions: Pittsburgh and Luzerne County. The Pittsburgh system was reformed in 1987, and made less generous. The post-1987 system is contributory, requiring four percent of the worker's salary. The normal benefit after 20 years of service is 50 percent of average salary, but workers earn an increment of one percent per year of service over twenty, so a forty year veteran could earn 70 percent of peak salary. The one percent increment is capped at $\$ 100$ per month, but that is not limiting except for workers earning over $\$ 120,000$ per year. There is a reduction in payments equal to one-half of social security payments received after age 65.

The Luzerne County system includes a contributory component of five percent or more, and the retiree receives a pension equal to the actuarial value of that contribution plus interest. In addition, the employee receives a pension of between one and two percent per years of service, depending on the class of service. Thus a twenty year worker might expect to receive 30 percent of final salary plus the accumulated value of total pensions. 
The average Ohio annuity per recipient in 2010 was $\$ 22,500 .{ }^{10}$ While this is higher than the Pennsylvania average, the numbers are not exactly comparable, both because of Social Security, and because the Pennsylvania benefits number includes other benefits. Moreover, the Ohio plan requires a fairly high level of member contribution.

The core Ohio plan requires a ten percent member contribution. It also offers a range of plan options, including one that allows members to direct their investments and a traditional pension plan. The traditional plan offers 2.2 percent of final salary per year of service, up to 30 years, and 2.5 percent of final salary per year of service after that point. As such, a forty year veteran of the system can expect to receive 91 percent of final salary. Ohio workers do not participate in Social Security.

Overall, the Ohio plan seems to be distinctly less generous than Pittsburgh's plan, which is particularly obvious for workers with less than 25 years of service, since the payment is the same as a share of earnings and the contribution rate is far higher. Indeed, given reasonable assumptions about the discount rate, the higher contribution rate in Ohio more than compensates for the higher payment rate in Pittsburgh.

When comparing the Ohio and Luzerne plans, it is perhaps easiest to assume that, since Ohio public employers contribute 14 percent of salary, they are paying for 60 percent of the Ohio plan, and possibly more if the plan is underfunded. In that case, the employer-funded Ohio plan amounts to around 1.4 percent per year of service making it roughly comparable to the Luzerne county plan.

Overall, Ohio's centralization does seem to generate distinctly less generosity than we see in Pittsburgh pensions, but no more than in Luzerne County. Centralization of pensions does not seem to be a magic bullet, but it does seem to avoid some of the more extreme cases that do occur in Pennsylvania.

Pennsylvania's local control has also led some communities to get into particularly large funding shortfalls. Some of the Pennsylvania cases, like Scranton, are especially extreme, like those in California, and these extremes may lead to particularly bad local outcomes. Only 28.4 percent of Scranton's pensions for non-uniformed employees are funded. By contrast, the official degree of funding in the Ohio system claims to be 74 percent. The Novy-Marx and Rauh (2009) estimates are less than forty percent for Ohio, but presumably the Scranton underfunding using their methodology would seem even more extreme.

These simple comparisons are not natural experiments, and they are not even properly controlled regressions. They do, however, point out that centralized plans seem not to have led to extreme pension generosity. Local plans can be modest, especially when (as in Luzerne County) resources are limited. But in larger local jurisdictions, both in California and Pennsylvania, the pension plans do seem to be quite generous, certainly more so than the two comparison centralized plans that we considered.

\section{Conclusion}

This paper has presented a model of the political economy of public sector pensions. The model suggests that pensions are likely to be generous, in part, because pension promises are less easily observable than promises about more direct forms of compensation. The

\footnotetext{
${ }^{10}$ https://www.opers.org/pubs-archive/investments/cafr/2010_CAFR_LoRes.pdf
} 
shrouded nature of public pensions presents one explanation for why they are typically far more generous in the public than in the private sector. The model also predicts that pensions will be more generous when public-sector workers are more likely to live in the community or when pre-funding requirements are lower.

In the model, pensions are inefficiently generous. Redistributing between public-sector workers and taxpayers could be either good or bad depending on one's perspective, but the model implies that public-sector worker welfare can be improved, holding total public sector costs fixed, if pensions are reduced and wages increased. This finding is corroborated by Fitzpatrick's (2012) finding that many teachers are unwilling to buy larger pensions, even at a small fraction of their total cost.

The implications of the model go far beyond pensions to all forms of compensation that are difficult to evaluate. Healthcare promises, particularly for retirees, are doubly shrouded. They involve promises far in the future, involving in-kind benefits that are inherently difficult to evaluate. The shrouded nature of these benefits can explain why public sector health care costs have been particularly high.

The model does not specifically discuss different types of public projects, but there as well, shrouding should matter. If the costs of large-scale infrastructure projects are difficult to assess, then we should not be surprised to see that the public sector has a penchant for such undertakings. Certainly, there has been a regular tendency to understate the cost of these projects and overstate the projected revenues.

The results of the model enable us to analyze the choice of centralization over pension rules. Centralization leads to more overall information and often less information asymmetry between public-sector workers and taxpayers. Centralization also ensures that public-sector workers will all vote in the election. The impact of centralization on pension generosity depends on whether the informational force dominates or whether the impact of union voting dominates. Since union workers are likely to live in big cities, we speculate that moving to centralized control over big city pensions may be particularly likely to reduce generosity.

We then used the logic of the model to discuss four states. In two of these states, Ohio and Massachusetts, local pension benefits are determined at the state level. In the other two states, California and Pennsylvania, benefits are set locally. In our examples, centralized control appeared to reduce pension generosity. If this conclusion is correct, then it suggests the power of shrouding. A primary difference between state and local control is that state-wide institutions, including the media, will be focused on the costs of state level compensation. This should have the impact of reducing shrouding and reducing the back-loading of compensation.

Transparency is a watchword in public policy today, and this paper formalizes the costs of limited transparency. Shrouding is the opposite of transparency, and in our model shrouding creates the potential for considerable social losses. The remaining question is what institutions can significantly reduce the adverse consequences of the shrouded costs of government. 


\section{A Appendix}

\section{A.1. Proof of Lemma 2}

Symmetry of wage information equals

$$
\rho_{w}=\frac{\underline{\theta}_{L}}{\underline{\theta}_{L}+\underline{\theta}_{U}-\underline{\theta}_{L} \underline{\theta}_{U}},
$$

such that

$$
\frac{\partial \rho_{w}}{\partial \underline{\theta}_{L}}=\frac{\underline{\theta}_{U}}{\left(\underline{\theta}_{L}+\underline{\theta}_{U}-\underline{\theta}_{L} \underline{\theta}_{U}\right)^{2}}>0
$$

and

$$
\frac{\partial \rho_{w}}{\partial \underline{\theta}_{U}}=-\frac{\underline{\theta}_{L}\left(1-\underline{\theta}_{L}\right)}{\left(\underline{\theta}_{L}+\underline{\theta}_{U}-\underline{\theta}_{L} \underline{\theta}_{U}\right)^{2}}<0 .
$$

Symmetry of pension information equals

$$
\rho_{B}=\frac{\underline{\theta}_{L}}{\underline{\theta}_{L}+\underline{\theta}_{U}-\pi \underline{\theta}_{L} \underline{\theta}_{U}}
$$

such that

$$
\frac{\partial \rho_{B}}{\partial \underline{\theta}_{L}}=\frac{\underline{\theta}_{U}}{\left(\underline{\theta}_{L}+\underline{\theta}_{U}-\pi \underline{\theta}_{L} \underline{\theta}_{U}\right)^{2}}>0
$$

and

$$
\frac{\partial \rho_{B}}{\partial \underline{\theta}_{U}}=-\frac{\underline{\theta}_{L}\left(1-\pi \underline{\theta}_{L}\right)}{\left(\underline{\theta}_{L}+\underline{\theta}_{U}-\pi \underline{\theta}_{L} \underline{\theta}_{U}\right)^{2}}<0,
$$

as well as

$$
\frac{\partial \rho_{B}}{\partial \pi}=\frac{\left(\pi \underline{\theta}_{L}\right)^{2} \underline{\theta}_{U}}{\left[1-\left(1-\pi \underline{\theta}_{L}\right)\left(1-\pi \underline{\theta}_{U}\right)\right]^{2}}>0,
$$

which implies $\rho_{B}<\rho_{w}$ for all $\pi<1$.

The ratio

$$
\frac{\rho_{B}}{\rho_{w}}=\frac{\underline{\theta}_{L}+\underline{\theta}_{U}-\underline{\theta}_{L} \underline{\theta}_{U}}{\underline{\theta}_{L}+\underline{\theta}_{U}-\pi \underline{\theta}_{L} \underline{\theta}_{U}}<1
$$

has derivatives

$$
\frac{\partial\left(\rho_{B} / \rho_{w}\right)}{\partial \underline{\theta}_{L}}=\frac{-(1-\pi) \underline{\theta}_{U}^{2}}{\left(\underline{\theta}_{L}+\underline{\theta}_{U}-\pi \underline{\theta}_{L} \underline{\theta}_{U}\right)^{2}}<0,
$$

and

$$
\frac{\partial\left(\rho_{B} / \rho_{w}\right)}{\partial \underline{\theta}_{U}}=\frac{-(1-\pi) \underline{\theta}_{L}^{2}}{\left(\underline{\theta}_{L}+\underline{\theta}_{U}-\pi \underline{\theta}_{L} \underline{\theta}_{U}\right)^{2}}<0,
$$

as well as

$$
\frac{\partial\left(\rho_{B} / \rho_{w}\right)}{\partial \pi}=\frac{\underline{\theta}_{L} \underline{\theta}_{U}\left(\underline{\theta}_{L}+\underline{\theta}_{U}-\underline{\theta}_{L} \underline{\theta}_{U}\right)}{\left(\underline{\theta}_{L}+\underline{\theta}_{U}-\pi \underline{\theta}_{L} \underline{\theta}_{U}\right)^{2}}>0 .
$$




\section{A.2. Proof of Proposition 1}

We conjecture that house prices are linear in pension debt

$$
H(x)=H+h(B-x)
$$

where $H>0$ is the steady-state house value and $h>0$ the response of house prices to inherited pension obligations.

This guess implies that the equilibrium condition for pensions also describes the linear rule

$$
B(x)=\frac{B-h x}{1-h}
$$

where

$$
B=R+\frac{\tilde{\gamma} q(1-h)}{\rho_{w} \phi q^{2}+\rho_{B}(1-q)(\phi q+h)} \frac{\beta(1+r) \bar{A}}{1+\beta}
$$

denotes the steady-state level of pensions.

Then the wage function must satisfy at the same time

$$
w(x)=\frac{1}{q}\left\{\begin{array}{r}
Y-\bar{A}-\frac{R}{1+r}+\frac{h}{1-h} \frac{x-B}{1+r}-\frac{(1-\phi) q}{1+\delta} x \\
-\frac{\phi q}{1+r} \frac{B-h x}{1-h}-\frac{r[H+h(B-x)]}{1+r}
\end{array}\right\}
$$

to keep taxpayers at their reservation utility and

$$
w(x)=\frac{1}{1-q}\left\{\frac{\tilde{\gamma}}{\rho_{w}} \frac{\bar{A}}{1+\beta}+\frac{(1-\phi) q}{1+\delta} x+\frac{\phi q}{1+r} \frac{B-h x}{1-h}+\frac{r[H+h(B-x)]}{1+r}\right\}
$$

to keep public employees at their equilibrium consumption ratio while working. The first wage function draws a decreasing function of $H$ : the willingness to pay by taxpayers as a function of housing prices. The second wage function draws an increasing function of $H$ : the political demand of public employees as a function of housing prices.

The two wage functions coincide for all $x$ if and only if $h \in[0,1)$ is such that

$$
\frac{r}{1+r} h^{2}-\left[1+\frac{(1-\phi) q(r-\delta)}{(1+\delta)(1+r)}\right] h+\frac{(1-\phi) q}{1+\delta}=0
$$

while

$$
H=\frac{1+r}{r}\left[(1-q)\left(Y-A^{T}-\frac{R}{1+r}\right)-q \frac{\tilde{\gamma}}{\rho_{w}} \frac{\bar{A}}{1+\beta}\right]-\frac{\phi q+(1-q+r) h-r h^{2}}{(1-h) r} B
$$

Finally, the wage function is

$$
w(x)=w+\frac{h}{1-h} \frac{x-B}{1+r}
$$

for a steady-state value

$$
w=\frac{\tilde{\gamma}}{\rho_{w}} \frac{\bar{A}}{1+\beta}-\bar{A}+Y-\frac{R}{1+r},
$$


and this jointly with the definition of $h$ implies that

$$
H=\frac{1+r}{r}\left[Y-\bar{A}-\frac{R}{1+r}-q w-\left(\frac{\phi}{1+r}+\frac{1-\phi}{1+\delta}\right) q B\right] .
$$

The quadratic that defines $h$ has a positive coefficient on $h^{2}$. It is positive at zero (for $\phi<1)$ and negative at $(1-\phi) q /(1+\delta)$. Thus it has a unique root in $[0,(1-\phi) q /(1+\delta)]$ and a negative slope at that root. Its comparative statics are unambiguous:

$$
\begin{gathered}
\frac{\partial h}{\partial \delta}=-\frac{(1-\phi) q(1+r)(1-h)}{(1+\delta)[(1+\delta)(1+r)+(1-\phi) q(r-\delta)-2(1+\delta) r h]}<0 \\
\frac{\partial h}{\partial \phi}=-\frac{q[1+r-(r-\delta) h]}{(1+\delta)(1+r)+(1-\phi) q(r-\delta)-2(1+\delta) r h}<0 \\
\frac{\partial h}{\partial q}=\frac{(1-\phi)[1+r-(r-\delta) h]}{(1+\delta)(1+r)+(1-\phi) q(r-\delta)-2(1+\delta) r h}>0
\end{gathered}
$$

and

$$
\frac{\partial h}{\partial r}=\frac{(1+\delta)[(1-\phi) q(r-\delta)+(1+\delta) h] h}{(1+r)[(1+\delta)(1+r)+(1-\phi) q(r-\delta)-2(1+\delta) r h]}>0 .
$$

Equilibrium dynamics converge to a steady state for all $q<1 / 2$, which implies a fortiori $h<1 / 2$.

\section{A.3. Proof of Proposition 2}

The steady-state wage $w$ is independent of $h$ and all its comparative statics are immediate:

$$
\frac{\partial w}{\partial \tilde{\gamma}}>0, \frac{\partial w}{\partial \rho_{w}}<0, \frac{\partial w}{\partial R}<0, \frac{\partial w}{\partial Y}>0, \text { and } \frac{\partial w}{\partial \rho_{B}}=\frac{\partial w}{\partial \delta}=\frac{\partial w}{\partial \phi}=0
$$

while

$$
\frac{\partial w}{\partial \bar{A}}=\frac{\tilde{\gamma}}{(1+\beta) \rho_{w}}-1
$$

remains ambiguous. Steady-state consumption by public employees while working is

$$
C_{W}^{P}=\frac{\tilde{\gamma}}{\rho_{w}} \frac{\bar{A}}{1+\beta}
$$

with immediate comparative statics

$$
\frac{\partial C_{W}^{P}}{\partial \tilde{\gamma}}>0, \frac{\partial C_{W}^{P}}{\partial \rho_{w}}<0 \frac{\partial C_{W}^{P}}{\partial \bar{A}}>0, \text { and } \frac{\partial C_{W}^{P}}{\partial \rho_{B}}=\frac{\partial C_{W}^{P}}{\partial \delta}=\frac{\partial C_{W}^{P}}{\partial \phi}=\frac{\partial C_{W}^{P}}{\partial R}=\frac{\partial C_{W}^{P}}{\partial Y}=0 .
$$

Steady-state consumption by public employees while retired is

$$
C_{R}^{P}=\frac{\tilde{\gamma}(1-h) q}{\phi\left[\rho_{w} q+\rho_{B}(1-q)\right] q+\rho_{B} h(1-q)} \frac{\beta(1+r) \bar{A}}{1+\beta},
$$


with immediate comparative statics

$$
\frac{\partial C_{R}^{P}}{\partial \tilde{\gamma}}>0, \frac{\partial C_{R}^{P}}{\partial \rho_{w}}<0, \frac{\partial C_{R}^{P}}{\partial \rho_{B}}<0, \frac{\partial C_{R}^{P}}{\partial \delta} \propto-\frac{\partial h}{\partial \delta}>0, \frac{\partial C_{R}^{P}}{\partial \bar{A}}>0, \frac{\partial C_{R}^{P}}{\partial R}=\frac{\partial C_{R}^{P}}{\partial Y}=0 .
$$

Steady-state pensions $B=R+C_{R}^{P}$ have identical comparative statics except $\partial B / \partial R=1$.

The derivative of steady-state pensions with respect to the level of pre-funding is

$$
\begin{aligned}
\frac{\partial B}{\partial \phi}= & -\frac{\tilde{\gamma} q}{\left\{\phi\left[\rho_{w} q+\rho_{B}(1-q)\right] q+\rho_{B} h(1-q)\right\}^{2}} \frac{\beta(1+r) A^{T}}{1+\beta} \\
& \cdot\left(\left[\rho_{w} q+\rho_{B}(1-q)\right](1-h) q+\left\{\phi\left[\rho_{w} q+\rho_{B}(1-q)\right] q+\rho_{B}(1-q)\right\} \frac{\partial h}{\partial \phi}\right),
\end{aligned}
$$

such that $\partial B / \partial \phi<0$ if and only if

$$
-\frac{\partial h}{\partial \phi}<\frac{\left[\rho_{w} q+\rho_{B}(1-q)\right](1-h) q}{\phi\left[\rho_{w} q+\rho_{B}(1-q)\right] q+\rho_{B}(1-q)} .
$$

The right-hand side is increasing in $\rho_{w}$ and decreasing in $\rho_{B}$. For $\rho_{w} \geq \rho_{B}$ the condition is most difficult to satisfy for $\rho_{w}=\rho_{B}$, which reduces it to

$$
-\frac{\partial h}{\partial \phi}<\frac{(1-h) q}{1-q+\phi q}
$$

For ease of notation, define

$$
\Phi \equiv(1-\phi) q
$$

Write out

$$
\frac{(1+r)-(r-\delta) h}{(1+\delta)(1+r)+(r-\delta) \Phi-2(1+\delta) r h} \leq \frac{1-h}{1-\Phi}
$$

bring up the denominators,

$$
\begin{aligned}
2(1+\delta) r h^{2}+\{(r-\delta)(1-\Phi) & -2(1+\delta) r-(1+\delta)(1+r)-(r-\delta) \Phi\} h \\
& +(1+\delta)(1+r)+(r-\delta) \Phi-(1+r)(1-\Phi) \geq 0,
\end{aligned}
$$

and plug in from the definition of $h$

$$
(1+\delta) r h^{2}=[(1+\delta)(1+r)+(r-\delta) \Phi] h-(1+r) \Phi,
$$

to reduce the condition to

$$
(1-\delta r) h \geq(1+\delta) \Phi-\delta(1+r) .
$$

1. If $\delta r<1$, then $\partial B / \partial \phi<0$ if and only if

$$
h \geq \frac{(1+\delta) \Phi-\delta(1+r)}{1-\delta r},
$$

which is satisfied because the quadratic that defines $h$, evaluated at the right-hand side of this expression, equals

$$
\frac{\delta(1+r)(1-\Phi)^{2}}{(1-r \delta)^{2}} \geq 0
$$


2. If $\delta r \geq 1$, then $\partial B / \partial \phi<0$ if and only if

$$
(1+\delta)(1-\Phi)+(\delta r-1)(1-h) \geq 0,
$$

which is satisfied because $h \leq \Phi \leq 1$.

\section{A.4. Proof of Proposition 3}

Steady-state house prices $H$ have comparative statics

$$
\begin{aligned}
& \frac{\partial H}{\partial \tilde{\gamma}} \propto-\frac{\partial w}{\partial \tilde{\gamma}}-\left(\frac{\phi}{1+r}+\frac{1-\phi}{1+\delta}\right) \frac{\partial B}{\partial \tilde{\gamma}}<0, \\
& \frac{\partial H}{\partial \rho_{w}} \propto-\frac{\partial w}{\partial \rho_{w}}-\left(\frac{\phi}{1+r}+\frac{1-\phi}{1+\delta}\right) \frac{\partial B}{\partial \rho_{w}}>0, \\
& \frac{\partial H}{\partial \rho_{B}} \propto-\frac{\partial w}{\partial \rho_{B}}-\left(\frac{\phi}{1+r}+\frac{1-\phi}{1+\delta}\right) \frac{\partial B}{\partial \rho_{B}}>0, \\
& \frac{\partial H}{\partial \phi} \propto \frac{(r-\delta) B}{(1+\delta)(1+r)}-\left(\frac{\phi}{1+r}+\frac{1-\phi}{1+\delta}\right) \frac{\partial B}{\partial \phi}>0 \text { for all } r>\delta, \\
& \frac{\partial H}{\partial \bar{A}} \propto-\frac{1}{q}-\frac{\partial w}{\partial \bar{A}}-\left(\frac{\phi}{1+r}+\frac{1-\phi}{1+\delta}\right) \frac{\partial B}{\partial \bar{A}} \\
& =-\frac{1-q}{q}-\frac{\tilde{\gamma}}{\rho_{w}} \frac{1}{1+\beta}-\left(\frac{\phi}{1+r}+\frac{1-\phi}{1+\delta}\right) \frac{\partial B}{\partial \bar{A}}<0, \\
& \frac{\partial H}{\partial R} \propto-\frac{1}{q(1+r)}-\frac{\partial w}{\partial R}-\left(\frac{\phi}{1+r}+\frac{1-\phi}{1+\delta}\right) \frac{\partial B}{\partial R} \\
& =-\frac{1-q}{q(1+r)}-\left(\frac{\phi}{1+r}+\frac{1-\phi}{1+\delta}\right) \frac{\partial B}{\partial R}<0,
\end{aligned}
$$

and

$$
\frac{\partial H}{\partial Y} \propto \frac{1}{q}-\frac{\partial w}{\partial Y}=\frac{1-q}{q}>0
$$

\section{A.5. Proof of Proposition 4}

Comparative statics for the steady-state welfare of public employees follow immediately from proposition 2. Developer profits equal

$$
\Pi=\frac{1}{1+\delta}\left[H_{0}+\delta \sum_{t=0}^{\infty}\left(\frac{1+\delta}{1+r}\right)^{t} H_{t}+(1-\phi) q B_{0}\right]
$$

Plugging in the equilibrium evolution of house prices,

$$
\Pi=\frac{1}{1+\delta}\left\{H+h\left(B-B_{0}\right)+\delta \sum_{t=0}^{\infty}\left(\frac{1+\delta}{1+r}\right)^{t}\left[H+h\left(B-B_{t}\right)\right]+(1-\phi) q B_{0}\right\} .
$$


Plugging in the equilibrium dynamics of public pensions,

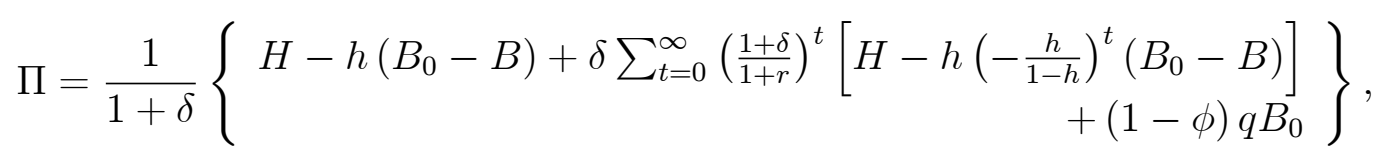

and solving the series

$$
\Pi=\frac{r}{r-\delta} H-\frac{(1+r)-r h}{(1+r)-(r-\delta) h} h\left(B_{0}-B\right)+\frac{(1-\phi) q}{1+\delta} B_{0} .
$$

Plugging in the definition of $h$,

$$
\Pi=\frac{r}{r-\delta} H+\frac{(1-\phi) q}{(1+\delta)} B .
$$

Finally, plugging in the steady-state value of $H$,

$$
\Pi=\frac{1+r}{r-\delta}\left[Y-\bar{A}-\frac{R}{1+r}-q\left(w+\frac{B}{1+r}\right)\right] .
$$

The comparative statics are

$$
\begin{gathered}
\frac{\partial \Pi}{\partial \tilde{\gamma}} \propto-\frac{\partial w}{\partial \tilde{\gamma}}-\frac{1}{1+r} \frac{\partial B}{\partial \tilde{\gamma}}<0 \text { and } \frac{\partial \Pi}{\partial \rho_{w}} \propto-\frac{\partial w}{\partial \rho_{w}}-\frac{1}{1+r} \frac{\partial B}{\partial \rho_{w}}>0, \\
\frac{\partial \Pi}{\partial \rho_{B}} \propto-\frac{\partial B}{\partial \rho_{B}}>0 \text { and } \frac{\partial \Pi}{\partial \phi} \propto-\frac{\partial B}{\partial \phi}>0 \\
\frac{\partial \Pi}{\partial \bar{A}} \propto-\frac{1}{q}-\frac{\partial w}{\partial \bar{A}}-\frac{1}{1+r} \frac{\partial B}{\partial \bar{A}}=-\frac{1-q}{q}-\frac{\tilde{\gamma}}{\rho_{w}} \frac{1}{1+\beta}-\frac{1}{1+r} \frac{\partial B}{\partial \bar{A}}<0, \\
\frac{\partial \Pi}{\partial R} \propto-\frac{1}{q}-(1+r) \frac{\partial w}{\partial R}-\frac{\partial B}{\partial R}=-\frac{1-q}{q}-\frac{\partial B}{\partial R}<0,
\end{gathered}
$$

and

$$
\frac{\partial \Pi}{\partial Y} \propto \frac{1}{q}-\frac{\partial w}{\partial Y}=\frac{1-q}{q}>0 .
$$

\section{A.6. Proof of Proposition 5}

Backloading is

$$
\Gamma=\frac{(1-h) q}{\phi q^{2}+\frac{\rho_{B}}{\rho_{w}}(1-q)(\phi q+h)} .
$$

The comparative statics for $C_{R}^{P}$ imply identically for $\Gamma$ that $\partial \Gamma / \partial \phi<0$ and $\partial \Gamma / \partial \delta>0$, while

$$
\frac{\partial \Gamma}{\partial\left(\rho_{B} / \rho_{w}\right)}=-\frac{(1-h) q(1-q)(\phi q+h)}{\left[\phi q^{2}+\frac{\rho_{B}}{\rho_{w}}(1-q)(\phi q+h)\right]^{2}}<0 .
$$

Consequently

$$
0<\frac{\rho_{B}}{\rho_{w}}<1 \Rightarrow \frac{(1-h) q}{\phi q+(1-q) h}<\Gamma<\frac{1-h}{\phi q},
$$

and therefore

$$
0<h<\frac{1-\phi}{1+\delta} q \Rightarrow 1+\frac{\delta(1-\phi)}{1-q+\delta \phi+\phi q}<\Gamma<\frac{1}{\phi q} .
$$




\section{A.7. Proof of Lemma 3 and Proposition 9}

Symmetry of wage information equals

$$
\rho_{w}^{S}=\frac{1-\left(1-\underline{\theta}_{L}\right)\left(1-\underline{\theta}_{S}\right)}{1-\left(1-\underline{\theta}_{L}\right)\left(1-\underline{\theta}_{S}\right)\left(1-\underline{\theta}_{U}\right)},
$$

such that

$$
\begin{gathered}
\frac{\partial \rho_{w}^{S}}{\partial \underline{\theta}_{L}}=\frac{\left(1-\underline{\theta}_{S}\right) \underline{\theta}_{U}}{\left[1-\left(1-\underline{\theta}_{L}\right)\left(1-\underline{\theta}_{S}\right)\left(1-\underline{\theta}_{U}\right)\right]^{2}}>0, \\
\frac{\partial \rho_{w}^{S}}{\partial \underline{\theta}_{U}}=-\frac{\left(1-\underline{\theta}_{L}\right)\left(1-\underline{\theta}_{S}\right)\left[1-\left(1-\underline{\theta}_{L}\right)\left(1-\underline{\theta}_{S}\right)\right]}{\left[1-\left(1-\underline{\theta}_{L}\right)\left(1-\underline{\theta}_{S}\right)\left(1-\underline{\theta}_{U}\right)\right]^{2}}<0,
\end{gathered}
$$

and

$$
\frac{\partial \rho_{w}^{S}}{\partial \underline{\theta}_{S}}=\frac{\left(1-\underline{\theta}_{L}\right) \underline{\theta}_{U}}{\left[1-\left(1-\underline{\theta}_{L}\right)\left(1-\underline{\theta}_{S}\right)\left(1-\underline{\theta}_{U}\right)\right]^{2}}>0
$$

which implies $\rho_{w}^{S}>\rho_{w}^{L}$ for all $\underline{\theta}_{S}>0$.

Symmetry of pension information equals

$$
\rho_{B}^{S}=\frac{1-\left(1-\pi \underline{\theta}_{L}\right)\left(1-\pi \underline{\theta}_{S}\right)}{1-\left(1-\pi \underline{\theta}_{L}\right)\left(1-\pi \underline{\theta}_{S}\right)\left(1-\pi \underline{\theta}_{U}\right)},
$$

such that

$$
\begin{gathered}
\frac{\partial \rho_{B}^{S}}{\partial \underline{\theta}_{L}}=\frac{\pi^{2}\left(1-\pi \underline{\theta}_{S}\right) \underline{\theta}_{U}}{\left[1-\left(1-\pi \underline{\theta}_{L}\right)\left(1-\pi \underline{\theta}_{S}\right)\left(1-\pi \underline{\theta}_{U}\right)\right]^{2}}>0, \\
\frac{\partial \rho_{B}^{S}}{\partial \underline{\theta}_{U}}=-\frac{\pi\left(1-\pi \underline{\theta}_{L}\right)\left(1-\pi \underline{\theta}_{S}\right)\left[1-\left(1-\pi \underline{\theta}_{L}\right)\left(1-\pi \underline{\theta}_{S}\right)\right]}{\left[1-\left(1-\pi \underline{\theta}_{L}\right)\left(1-\pi \underline{\theta}_{S}\right)\left(1-\pi \underline{\theta}_{U}\right)\right]^{2}}<0,
\end{gathered}
$$

and

$$
\frac{\partial \rho_{B}^{S}}{\partial \underline{\theta}_{S}}=\frac{\pi^{2}\left(1-\pi \underline{\theta}_{L}\right) \underline{\theta}_{U}}{\left[1-\left(1-\pi \underline{\theta}_{L}\right)\left(1-\pi \underline{\theta}_{S}\right)\left(1-\pi \underline{\theta}_{U}\right)\right]^{2}}>0
$$

which implies $\rho_{B}^{S}>\rho_{B}^{L}$ for all $\underline{\theta}_{S}>0$; as well as

$$
\frac{\partial \rho_{B}^{S}}{\partial \pi}=\pi^{2} \underline{\theta}_{U} \frac{\theta_{L}^{2}\left(1-\pi \theta_{S}\right)^{2}+\theta_{L} \theta_{S}\left(1-\pi^{2} \theta_{L} \theta_{S}\right)+\left(1-\pi \theta_{L}\right)^{2} \theta_{S}^{2}}{\left[1-\left(1-\pi \underline{\theta}_{L}\right)\left(1-\pi \underline{\theta}_{S}\right)\left(1-\pi \underline{\theta}_{U}\right)\right]^{2}}>0,
$$

which implies $\rho_{B}^{S}<\rho_{w}^{S}$ for all $\pi<1$.

The ratio

$$
\frac{\rho_{B}^{S}}{\rho_{w}^{S}}=\frac{1-\left(1-\pi \underline{\theta}_{L}\right)\left(1-\pi \underline{\theta}_{S}\right)}{1-\left(1-\pi \underline{\theta}_{L}\right)\left(1-\pi \underline{\theta}_{S}\right)\left(1-\pi \underline{\theta}_{U}\right)} \frac{1-\left(1-\underline{\theta}_{L}\right)\left(1-\underline{\theta}_{S}\right)\left(1-\underline{\theta}_{U}\right)}{1-\left(1-\underline{\theta}_{L}\right)\left(1-\underline{\theta}_{S}\right)}
$$

has derivative $\partial\left(\rho_{B}^{S} / \rho_{w}^{S}\right) / \partial \pi>0$ because $\partial \rho_{B}^{S} / \partial \pi>0$ while $\partial \rho_{w}^{S} / \partial \pi=0$. Moreover

$$
\begin{aligned}
& \frac{\partial\left(\rho_{B}^{S} / \rho_{w}^{S}\right)}{\partial \underline{\theta}_{U}}=-\pi(1-\pi) \frac{1-\left(1-\pi \underline{\theta}_{L}\right)\left(1-\pi \underline{\theta}_{S}\right)}{1-\left(1-\underline{\theta}_{L}\right)\left(1-\underline{\theta}_{S}\right)} \\
& \quad \cdot \frac{\theta_{L}^{2}\left(1-\theta_{S}\right)^{2}+\theta_{L} \theta_{S}\left(1-\theta_{L} \theta_{S}\right)+\theta_{S}^{2}\left(1-\theta_{L}\right)^{2}+(1-\pi) \theta_{L} \theta_{S}\left(\theta_{L}+\theta_{S}-\theta_{L} \theta_{S}\right)}{\left[1-\left(1-\pi \underline{\theta}_{L}\right)\left(1-\pi \underline{\theta}_{S}\right)\left(1-\pi \underline{\theta}_{U}\right)\right]^{2}}
\end{aligned}
$$


Finally

$$
\begin{aligned}
\frac{\partial\left(\rho_{B}^{S} / \rho_{w}^{S}\right)}{\partial \underline{\theta}_{L}} & =\frac{(1-\pi) \underline{\theta}_{U}}{\left[1-\left(1-\pi \underline{\theta}_{L}\right)\left(1-\pi \underline{\theta}_{S}\right)\left(1-\pi \underline{\theta}_{U}\right)\right]^{2}\left[1-\left(1-\underline{\theta}_{L}\right)\left(1-\underline{\theta}_{S}\right)\right]^{2}} \\
& \cdot\left\{\underline{\theta}_{S}^{3}-\underline{\theta}_{L}\left(1-\underline{\theta}_{S}\right)\left(1-\pi \underline{\theta}_{S}\right)\left[2 \underline{\theta}_{S} \underline{\theta}_{U}+\underline{\theta}_{L}\left(\underline{\theta}_{S}+\underline{\theta}_{U}-\underline{\theta}_{S} \underline{\theta}_{U}-\pi \underline{\theta}_{S} \underline{\theta}_{U}\right)\right]\right\} .
\end{aligned}
$$

The last line is a quadratic in $\underline{\theta}_{L}$ with a negative coefficient on $\underline{\theta}_{L}^{2}$ and a positive value at zero. Thus

$$
\frac{\partial\left(\rho_{B}^{S} / \rho_{w}^{S}\right)}{\partial \underline{\theta}_{L}}>0 \Leftrightarrow 0<\underline{\theta}_{L}<\hat{\theta}_{L}
$$

for threshold $\hat{\theta}_{L}$ that can be above one (e.g., as $\underline{\theta}_{S} \rightarrow 1$ and $\left.\underline{\theta}_{U} \rightarrow 0\right)$. Since the ratio $\rho_{B}^{S} / \rho_{w}^{S}$ is symmetric in $\underline{\theta}_{L}$ and $\underline{\theta}_{S}$, the same result applies to $\underline{\theta}_{S}$.

Centralization reduces the relative asymmetry in information about pensions compared to wages if and only if

$$
\frac{\rho_{B}^{L}}{\rho_{w}^{L}}<\frac{\rho_{B}^{S}}{\rho_{w}^{S}} \Leftrightarrow \frac{\theta_{L}^{2}}{\left(1-\pi \theta_{L}\right)\left(1-\theta_{L}\right)}>\theta_{S} \theta_{U}
$$

and thus if and only if $\theta_{L}>\bar{\theta}_{L}$ for a threshold

$$
\bar{\theta}_{L} \in\left(0, \max \left\{\theta_{S}, \theta_{U}\right\}\right) \text { with } \frac{\partial \bar{\theta}_{L}}{\partial \theta_{S}}>0, \frac{\partial \bar{\theta}_{L}}{\partial \theta_{U}}>0 \text {, and } \frac{\partial \bar{\theta}_{L}}{\partial \pi}<0 \text {. }
$$

By the definition of backloading $\Gamma$,

$$
\theta_{L}>\bar{\theta}_{L} \Leftrightarrow \frac{\rho_{B}^{L}}{\rho_{w}^{L}}<\frac{\rho_{B}^{S}}{\rho_{w}^{S}} \Leftrightarrow \Gamma_{S}<\Gamma_{L}
$$

\section{A.8. Proof of Proposition 6}

Centralization reduces public employees' wages and their consumption when working if and only if

$$
\tilde{\gamma}>\bar{\gamma}_{w} \equiv \frac{\rho_{w}^{L}}{\rho_{w}^{S}}=\frac{\left(1-\omega_{L}\right)\left(1-\omega_{L} \omega_{S} \omega_{U}\right)}{\left(1-\omega_{L} \omega_{S}\right)\left(1-\omega_{L} \omega_{U}\right)}
$$

where we have defined disinformation $\omega_{i}=1-\underline{\theta}_{i}$. Then

$$
\begin{gathered}
\frac{\partial \bar{\gamma}_{w}}{\partial \omega_{L}}=-\frac{\left(1-\omega_{U}\right)\left(1-\omega_{S}\right)\left(1-\omega_{L}^{2} \omega_{S} \omega_{U}\right)}{\left(1-\omega_{L} \omega_{S}\right)^{2}\left(1-\omega_{L} \omega_{U}\right)^{2}}<0, \\
\frac{\partial \bar{\gamma}_{w}}{\partial \omega_{S}}=\frac{\omega_{L}\left(1-\omega_{L}\right)\left(1-\omega_{U}\right)}{\left(1-\omega_{L} \omega_{S}\right)^{2}\left(1-\omega_{L} \omega_{U}\right)}>0
\end{gathered}
$$

and

$$
\frac{\partial \bar{\gamma}_{w}}{\partial \omega_{U}}=\frac{\omega_{L}\left(1-\omega_{L}\right)\left(1-\omega_{S}\right)}{\left(1-\omega_{L} \omega_{S}\right)\left(1-\omega_{L} \omega_{U}\right)^{2}}>0
$$


Centralization reduces public employees' pensions and their consumption while retired if and only if

$$
\tilde{\gamma}>\bar{\gamma}_{B} \equiv \bar{\gamma}_{w} \frac{\Gamma_{S}}{\Gamma_{L}}=\frac{\rho_{w}^{L} \phi q^{2}+\rho_{B}^{L}(\phi q+h)(1-q)}{\rho_{w}^{S} \phi q^{2}+\rho_{B}^{S}(\phi q+h)(1-q)},
$$

such that $\partial \bar{\gamma}_{B} / \partial \underline{\theta}_{S}<0$ because $\underline{\theta}_{S}$ increases the denominator while leaving the numerator unchanged. Moreover

$$
\frac{\partial \bar{\gamma}_{B}}{\partial h}=-\frac{\left(\rho_{w}^{L} \rho_{B}^{S}-\rho_{w}^{S} \rho_{B}^{L}\right) \phi q^{2}(1-q)}{\left[\rho_{w}^{S} \phi q^{2}+\rho_{B}^{S}(\phi q+h)(1-q)\right]^{2}}
$$

and

so

$$
\frac{\partial \bar{\gamma}_{B}}{\partial \phi}=\frac{\left(\rho_{w}^{L} \rho_{B}^{S}-\rho_{w}^{S} \rho_{B}^{L}\right) q^{2}(1-q)}{\left[\rho_{w}^{S} \phi q^{2}+\rho_{B}^{S}(\phi q+h)(1-q)\right]^{2}}\left(h-\phi \frac{\partial h}{\partial \phi}\right),
$$

$$
\theta_{L}>\bar{\theta}_{L} \Leftrightarrow \Gamma_{S}<\Gamma_{L} \Leftrightarrow \frac{\rho_{B}^{L}}{\rho_{w}^{L}}<\frac{\rho_{B}^{S}}{\rho_{w}^{S}} \Leftrightarrow \frac{\partial \bar{\gamma}_{B}}{\partial \delta} \propto-\frac{\partial h}{\partial \delta}>0 \Leftrightarrow \frac{\partial \bar{\gamma}_{B}}{\partial \phi}>0 .
$$

At the same time,

$$
\theta_{L}>\bar{\theta}_{L} \Leftrightarrow \Gamma_{S}<\Gamma_{L} \Leftrightarrow \bar{\gamma}_{B}<\bar{\gamma}_{w} .
$$

\section{A.9. Proof of Proposition 7}

Centralization increases house prices if and only if

$$
\tilde{\gamma}>\bar{\gamma}_{H} \equiv \bar{\gamma}_{w} \frac{1+\beta\left[\phi+(1-\phi) \frac{1+r}{1+\delta}\right] \Gamma_{S}}{1+\beta\left[\phi+(1-\phi) \frac{1+r}{1+\delta}\right] \Gamma_{L}} .
$$

Rewriting

$$
\begin{aligned}
\bar{\gamma}_{H}=\left\{\frac{1}{\rho_{w}^{S}}+\frac{\beta\left[\phi+(1-\phi) \frac{1+r}{1+\delta}\right](1-h) q}{\rho_{w}^{S} \phi q^{2}+\rho_{B}^{S}(1-q)(\phi q+h)}\right\} \\
\cdot\left\{\frac{1}{\rho_{w}^{L}}+\frac{\beta\left[\phi+(1-\phi) \frac{1+r}{1+\delta}\right](1-h) q}{\rho_{w}^{L} \phi q^{2}+\rho_{B}^{L}(1-q)(\phi q+h)}\right\}^{-1}
\end{aligned}
$$

highlights that $\partial \bar{\gamma}_{H} / \partial \underline{\theta}_{S}<0$, because $\partial \rho_{w}^{S} / \partial \underline{\theta}_{S}>0$ and $\partial \rho_{B}^{S} / \partial \underline{\theta}_{S}>0$ while $\partial \rho_{w}^{L} / \partial \underline{\theta}_{S}=$ $\partial \rho_{B}^{L} / \partial \underline{\theta}_{S}=0$. Moreover

$$
\theta_{L}>\bar{\theta}_{L} \Leftrightarrow \Gamma_{S}<\Gamma_{L} \Leftrightarrow \bar{\gamma}_{B}<\bar{\gamma}_{H}<\bar{\gamma}_{w} .
$$

\section{A.10. Proof of Proposition 8}

Centralization reduces public employees' lifetime utility if and only if

$$
\tilde{\gamma}>\bar{\gamma}_{U} \equiv \bar{\gamma}_{w}\left(\frac{\Gamma_{S}}{\Gamma_{L}}\right)^{\frac{\beta}{1+\beta}}=\frac{\rho_{w}^{L}}{\rho_{w}^{S}}\left[\frac{\phi q^{2}+\frac{\rho_{B}^{L}}{\rho_{w}^{L}}(1-q)(\phi q+h)}{\phi q^{2}+\frac{\rho_{B}^{S}}{\rho_{w}^{S}}(1-q)(\phi q+h)}\right]^{\frac{\beta}{1+\beta}},
$$


such that $\partial \bar{\gamma}_{B} / \partial \underline{\theta}_{S}<0$ because $\underline{\theta}_{S}$ increases the denominator while leaving the numerator unchanged. Moreover

$$
\frac{\partial \bar{\gamma}_{U}}{\partial h} \propto \frac{\partial\left(\Gamma_{S} / \Gamma_{L}\right)}{\partial h}=\frac{-\left(\frac{\rho_{B}^{S}}{\rho_{w}^{S}}-\frac{\rho_{B}^{L}}{\rho_{w}^{L}}\right) \phi q^{2}(1-q)}{\left[\phi q^{2}+\frac{\rho_{B}^{L}}{\rho_{w}^{L}}(1-q)(\phi q+h)\right]^{2}\left[\phi q^{2}+\frac{\rho_{B}^{S}}{\rho_{w}^{S}}(1-q)(\phi q+h)\right]^{2}}
$$

and

$$
\begin{aligned}
\frac{\partial \bar{\gamma}_{U}}{\partial \phi} \propto \frac{\partial\left(\Gamma_{S} / \Gamma_{L}\right)}{\partial \phi} & \left(\frac{\rho_{B}^{S}}{\rho_{w}^{S}}-\frac{\rho_{B}^{L}}{\rho_{w}^{L}}\right) q^{2}(1-q) \\
& =\frac{\rho^{2}\left[\phi q^{2}+\frac{\rho_{B}^{S}}{\rho_{w}^{S}}(1-q)(\phi q+h)\right]^{2}}{\left[\phi q^{2}+\frac{\rho_{B}^{L}}{\rho_{w}^{L}}(1-q)(\phi q+h)\right]^{2}}\left(h \frac{\partial h}{\partial \phi}\right)
\end{aligned}
$$

such that

$$
\Gamma_{S}<\Gamma_{L} \Leftrightarrow \frac{\rho_{B}^{L}}{\rho_{w}^{L}}<\frac{\rho_{B}^{S}}{\rho_{w}^{S}} \Leftrightarrow \frac{\partial \bar{\gamma}_{U}}{\partial \delta}>0 \Leftrightarrow \frac{\partial \bar{\gamma}_{U}}{\partial \phi}>0 .
$$

Centralization increases developers' profits if and only if

$$
\tilde{\gamma}>\bar{\gamma}_{\Pi} \equiv \bar{\gamma}_{w} \frac{1+\beta \Gamma_{S}}{1+\beta \Gamma_{L}}
$$

Rewriting

$$
\bar{\gamma}_{H}=\left\{\frac{1}{\rho_{w}^{S}}+\frac{\beta(1-h) q}{\rho_{w}^{S} \phi q^{2}+\rho_{B}^{S}(1-q)(\phi q+h)}\right\}\left\{\frac{1}{\rho_{w}^{L}}+\frac{\beta(1-h) q}{\rho_{w}^{L} \phi q^{2}+\rho_{B}^{L}(1-q)(\phi q+h)}\right\}^{-1}
$$

highlights that $\partial \bar{\gamma}_{H} / \partial \underline{\theta}_{S}<0$, because $\partial \rho_{w}^{S} / \partial \underline{\theta}_{S}>0$ and $\partial \rho_{B}^{S} / \partial \underline{\theta}_{S}>0$ while $\partial \rho_{w}^{L} / \partial \underline{\theta}_{S}=$ $\partial \rho_{B}^{L} / \partial \underline{\theta}_{S}=0$.

Both thresholds are ranked by

$$
\theta_{L}>\bar{\theta}_{L} \Leftrightarrow \Gamma_{S}<\Gamma_{L} \Leftrightarrow \bar{\gamma}_{H}<\bar{\gamma}_{\Pi}<\bar{\gamma}_{U}<\bar{\gamma}_{w},
$$

since $\bar{\gamma}_{H}<\bar{\gamma}_{\Pi}$ for all $r>\delta$, while $\bar{\gamma}_{\Pi}<\bar{\gamma}_{U}$ if and only if

$$
\left(1+\beta \Gamma_{S}\right) \Gamma_{S}^{-\frac{\beta}{1+\beta}}<\left(1+\beta \Gamma_{L}\right) \Gamma_{L}^{-\frac{\beta}{1+\beta}},
$$

which is true if and only if $\Gamma_{S}<\Gamma_{L}$ because the function

$$
f(\Gamma)=(1+\beta \Gamma) \Gamma^{-\frac{\beta}{1+\beta}}
$$

is monotone increasing:

$$
f^{\prime}(\Gamma)=\frac{\beta(\Gamma-1)}{1+\beta} \Gamma^{-\frac{1}{1+\beta}}>0, \text { for all } \Gamma>1 .
$$




\section{References}

[1] Arnott, Richard J. and Joseph E. Stiglitz. 1979. "Aggregate Land Rents, Expenditure on Public Goods, and Optimal City Size." Quarterly Journal of Economics 93 (4): 471-500.

[2] Clark, Robert, Craig, Lee and Jack Wilson. 2003. A History of Public Pensions in the United States. Philadelphia: University of Pennsylvania Press.

[3] Fitzpatrick, Maria. 2012. "How Much do Public School Teachers Value Their Retierment Benefits?" Stanford Institute for Economic Research Working Paper.

[4] Freeman, Richard B. 1986. "Unionism Comes to the Public Sector." Journal of Economic Literature, 24(3): 41-86.

[5] Gabaix, Xavier and David Laibson. 2006. "Shrouded Attributes, Consumer Myopia, and Information Suppression in Competitive Markets." Quarterly Journal of Economics 121 (2): 505-540.

[6] Gentzkow, Matthew. 2006. "Television and voter turnout." Quarterly Journal of Economics 121 (3): 931-72.

[7] Glaeser, Edward L., Giacomo A. M. Ponzetto, and Jesse M. Shapiro. 2005. "Strategic Extremism: Why Republicans and Democrats Divide on Religious Values." Quarterly Journal of Economics 120 (4): 1283-1330.

[8] Graebner, William. 1978. "Retirement in Education: The Economic and Social Functions of the Teachers' Pension." History of Education Quarterly 18 (4): 397-417.

[9] Gyourko, Joseph and Joseph Tracy. 1989. "Local Public Sector Rent-Seeking and its Impact on Local Land Values." Regional Science and Urban Economics 19(3): 493-516.

[10] Lindbeck, A. and J. Weibull. 1987. "Balanced budget redistribution and the outcome of political competition." Public Choice 52 (3): 273-297.

[11] Leeds, Michael. 1985. "Property values and pension underfunding in the local public sector." Journal of Urban Economics 18(1)1:34 - 46.

[12] Mitchell, Olivia S. and David McCarthy. 1999. "The Structure and Performance of State and Local Pension Plans." Pension Research Council, The Wharton School, Philadelphia.

[13] Monahan, Amy B. 2012. "Statutes as Contracts? The 'California Rule' and Its Impact on Public Pension Reform." Iowa Law Review 97:1029-1083.

[14] Novy-Marx, Robert and Joshua D. Rauh. 2009. "The Liabilities and Risks of StateSponsored Pension Plans." Journal of Economic Perspectives 23 (4): 191-210.

[15] — 2011. "Public Pension Promises: How Big Are They and What Are They Worth?." Journal of Finance, 66: 1211-1249. 
[16] Ponzetto, Giacomo A. M. 2011. "Heterogeneous Information and Trade Policy." CEPR Discussion Paper 8726.

[17] Poterba, James, Venti, Steven and David Wise. 2007. "The Changing Landscape of Pensions in the United States." NBER Working Paper 13381.

[18] Smith, Robert Stewart. 1981. "Compensating Differentials for Pensions and Underfunding in the Public Sector." Review of Economics and Statistics 63 (3): 463-468

[19] Snyder, James M., and David Strömberg. 2010. "Press Coverage and Political Accountability." Journal of Political Economy 118 (2): 335-408. 


\section{TABLE 1:}

\section{PUBLIC PENSION PLANS BY STATE}

\begin{tabular}{|c|c|c|}
\hline STATE & DESCRIPTION & $\begin{array}{l}\text { SOCIAL } \\
\text { SECURITY }\end{array}$ \\
\hline Alabama & $\begin{array}{l}\text { - State employees (including state police) go through ERS } \\
\text { (Employee's Retirement System), though some State } \\
\text { agencies don't participate. } \\
\text { - } \quad \text { Teachers and judges have their own systems. } \\
\text { - } \quad \text { Localities are not required to join ERS, but if they do, ERS } \\
\text { has control over benefits and investments. } \\
\text { - Localities seem to have freedom in determining contribution } \\
\text { rates, even if under ERS. } \\
\text { - } \quad \text { MonS is a defined benefit plan. }\end{array}$ & $\begin{array}{l}\text { RSA participants } \\
\text { (ERS, TRS, JRF } \\
\text { members) have } \\
\text { access to SS. } \\
\text { Localities } \\
\text { choosing not to } \\
\text { participate in the } \\
\text { Retirement } \\
\text { Systems of } \\
\text { Alabama may } \\
\text { choose to replace } \\
\text { SS benefits. }\end{array}$ \\
\hline Alaska & 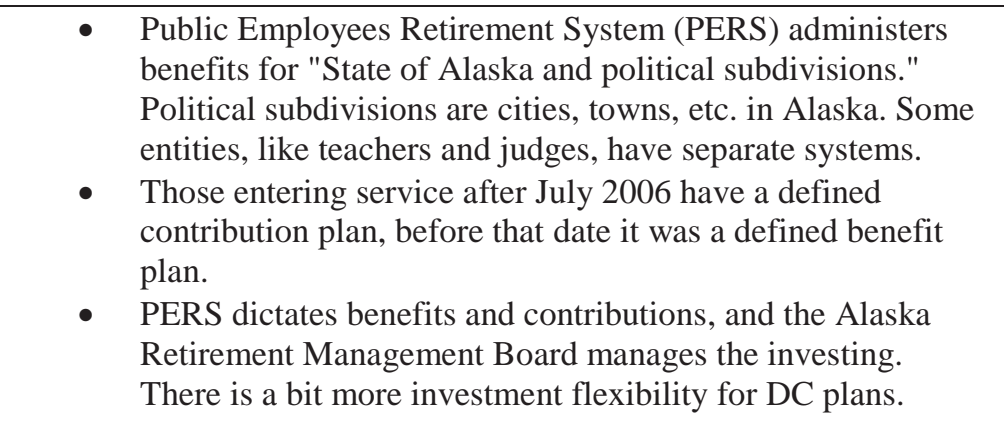 & $\begin{array}{l}\text { PERS/TRS DCR Plan } \\
\text { members have access to } \\
\text { SS benefits. }\end{array}$ \\
\hline Arizona & $\begin{array}{l}\text { - The Arizona State Retirement System is for both State and } \\
\text { Local governments. } \\
\text { Employers are required to collect and submit the } \\
\text { contributions by certain dates, or risk a fee or withholding of } \\
\text { money by the state. Investments are put into Arizona State } \\
\text { Retirement Fund. } \\
\text { - The main pension program is a 401(a) defined benefit plan. }\end{array}$ & $\begin{array}{l}\text { ASRS participants } \\
\text { have access to SS } \\
\text { benefits subject to } \\
\text { section } 218 \text { of the } \\
\text { SSA. }\end{array}$ \\
\hline Arkansas & $\begin{array}{l}\text { - State and Counties are required to join APERS } \\
\text { - There are separated plans for judges, police and fire, } \\
\text { teachers, etc. } \\
\text { - Plan is defined benefit, with "defined contribution options." } \\
\text { Localities can join voluntarily; however, one is hard pressed } \\
\text { to find any independent local systems (except for police and } \\
\text { fire). } \\
\text { - APERS determine benefits though there is some flexibility in } \\
\text { how they are paid out } \\
\text { - If in APERS, Board of Trustees hires an actuary firm to } \\
\text { figure out how much contributions should be and invests the } \\
\text { funds. }\end{array}$ & $\begin{array}{l}\text { APERS members } \\
\text { have access to SS } \\
\text { benefits. }\end{array}$ \\
\hline California & $\begin{array}{l}\text { - } \quad \text { CalPERS covers state employees, and local governments that } \\
\text { choose to join. Judges and legislatures have their own. } \\
\text { - } \quad \text { CalSTRS covers teachers. } \\
\text { - } \quad \text { Many local places, including San Francisco, have their own } \\
\text { - } \quad \text { Cystems. } \\
\text { - CalPERS dictates the benefit terms for its members (though }\end{array}$ & $\begin{array}{l}\text { CalPERS members may } \\
\text { not have access to SS } \\
\text { benefits. CalSTRS } \\
\text { (teachers) do not } \\
\text { participate in SS. }\end{array}$ \\
\hline
\end{tabular}




\begin{tabular}{|c|c|c|}
\hline & $\begin{array}{l}\text { there are different plans within CalPERS) } \\
\text { CalPERS also has contribution requirements for its member } \\
\text { governments, but parts can be negotiated, i.e. the employer } \\
\text { might pay for part of the employee's contribution, or parts } \\
\text { might be influenced by collective } \\
\text { - CalPERS also handles investments.At the end of } 2011 \\
\text { proposed changes were suggested. }\end{array}$ & \\
\hline Colorado & $\begin{array}{l}\text { Public Employees' Retirement Association (PERA) } \\
\text { "includes employees of the Colorado state government, } \\
\text { public school teachers in the state, many university and } \\
\text { college employees, judges, many employees of cities and } \\
\text { towns, state troopers, and the employees of a number of } \\
\text { other public entities." } \\
\text { Local governments are not required to join but can choose } \\
\text { to. } \\
\text { - Many local areas have their own, such as Denver (DERP) } \\
\text { - If under PERA, PERA dictates the benefits, the funding (8 } \\
\text { percent for most members, and benefits are prefunded; } \\
\text { employer funding varies), and investments. } \\
\text { - Member contributions earn a fixed interest rate }\end{array}$ & $\begin{array}{l}\text { PERA members do not } \\
\text { participate in SS. } \\
\text { Members of local } \\
\text { pension plans may have } \\
\text { access. DERP members, } \\
\text { for instance, have } \\
\text { access to SS benefits. }\end{array}$ \\
\hline Connecticut & $\begin{array}{l}\text { - There is a state employee retirement plan. Teachers have } \\
\text { their own (http://www.ct.gov/trb/site/default.asp). } \\
\text { - There is a municipal retirement system (CMERS), provided } \\
\text { by the state. Though many localities join, it doesn't seem } \\
\text { like membership is required. } \\
\text { - CMERS has a defined benefit plan } \\
\text { - If a locality is in CMERS, benefits are determined by } \\
\text { CMERS, there is a set amount to contribute, and the State } \\
\text { Retirement Commission manages investments. }\end{array}$ & $\begin{array}{l}\text { Most CMERS members } \\
\text { have access to SS } \\
\text { benefits, but some do } \\
\text { not. CTRB members } \\
\text { (teachers) do not } \\
\text { participate in SS. } \\
\text { PJERS members may or } \\
\text { may not have coverage - } \\
\text { each district has either } \\
\text { chosen to apply or not } \\
\text { to apply for coverage as } \\
\text { its own division. Some } \\
\text { CSERS members may } \\
\text { choose to opt out of SS, } \\
\text { while others participate. }\end{array}$ \\
\hline Delaware & $\begin{array}{l}\text { - State of Delaware has a state plan, along with a General } \\
\text { County and Municipal pension plan, along with a bunch of } \\
\text { others for judges, firefighters, etc. } \\
\text { - The State of Delaware Board of Pension Trustees } \\
\text { administers the Delaware Public Employees' Retirement } \\
\text { System. } \\
\text { - The plan's board defines the benefits of the City and } \\
\text { Municipal pension plan which is a defined benefit plan. } \\
\text { Localities are not required to join. } \\
\text { The plan's board determines contributions through an } \\
\text { actuary report and manages investments as well. }\end{array}$ & $\begin{array}{l}\text { Members of most plans } \\
\text { (state, state police, } \\
\text { judges, county and } \\
\text { municipal) have access } \\
\text { to SS benefits. } \\
\text { (Volunteer firemen } \\
\text { appear to not have SS } \\
\text { benefits.) }\end{array}$ \\
\hline Florida & $\begin{array}{l}\text { Florida Retirement System is the state level system. } \\
\text { Localities can join if they want. } \\
\text { It looks like benefits for localities are determined by the } \\
\text { localities. There is a lot of variation. } \\
\text { Local Retirement Board monitors all local government } \\
\text { retirement plans for soundness in funding. The Board also } \\
\text { rates the funds, but it's not clear what happens if the Board } \\
\text { "fails" or get a bad rating. Also rates them. }\end{array}$ & $\begin{array}{l}\text { Members of Florida's } \\
\text { DROP have access to } \\
\text { SS benefits, as do most } \\
\text { members of FRS plans. } \\
\text { Teachers do not } \\
\text { participate in SS. }\end{array}$ \\
\hline
\end{tabular}




\begin{tabular}{|c|c|c|}
\hline & $\begin{array}{l}\text { - It looks like each individual plan makes its own investment } \\
\text { decisions as they vary greatly. }\end{array}$ & \\
\hline Georgia & $\begin{array}{l}\text { - There is a general state employees system (ERSGA), as well } \\
\text { as one for public school employees, legislatures, judges, } \\
\text { military, superior court, and DAs } \\
\text { - Georgia Municipal Association exists, but it not required for } \\
\text { localities to join Atlanta, for instance, has its own plan. } \\
\text { - If a locality chooses to join GMA, GMA determines } \\
\text { benefits, contributions, and investments } \\
\text { - GMA is a defined benefit plan. }\end{array}$ & $\begin{array}{l}\text { Members of the Defined } \\
\text { Contribution plan do } \\
\text { not have access to SS } \\
\text { benefits. Access to SS } \\
\text { benefits varies by plan. }\end{array}$ \\
\hline Hawaii & $\begin{array}{l}\text { - State and county employees are under ERS (employees } \\
\text { retirement system) } \\
\text { - There are hybrid, noncontributory plans and contributory } \\
\text { plans (employees are put into different plans depending on } \\
\text { when they were hired) } \\
\text { - Different systems for police officers, fire fighters, judges, } \\
\text { etc. } \\
\text { - It appears smaller localities (below counties), such as } \\
\text { Honolulu, also are under ERS. } \\
\text { - ERS determines benefits and contribution, but there are } \\
\text { different plans and terms are different under each. } \\
\text { - Hawaii Targeted Investment Program invests. }\end{array}$ & $\begin{array}{l}\text { Most members of } \\
\text { the hybrid, } \\
\text { noncontributory } \\
\text { and contributory } \\
\text { plans are also } \\
\text { covered by SS. }\end{array}$ \\
\hline Idaho & $\begin{array}{l}\text { - } \quad \text { By law, "agencies of the State of Idaho and school districts } \\
\text { are PERSI members." Local governments can opt to join. } \\
\text { - } \quad \text { As PERSI's plan sponsor, the Idaho Legislature is } \\
\text { responsible for determining the benefit structure. } \\
\text { - The Board sets contribution rates for PERSI members. } \\
\text { - The Board oversees investments. For member locations of } \\
\text { PERSI, there is a base plan (DB) and a 401k plan. 401k plan } \\
\text { allows for more investment flexibility. }\end{array}$ & $\begin{array}{l}\text { PERSI members have } \\
\text { access to SS benefits. }\end{array}$ \\
\hline Illinois & $\begin{array}{l}\text { - Illinois has systems for the State, Teachers, University, } \\
\text { Judges, and General Assembly. } \\
\text { - Illinois Municipal Retirement Fund covers all counties } \\
\text { except Cook County and all school districts except those in } \\
\text { the City of Chicago. IMRF is not a state entity. } \\
\text { - IMRF is a defined benefit plan. } \\
\text { - Localities may choose to join. } \\
\text { - If part of IMRF, IMRF establishes benefits, controls funding } \\
\text { (with a 100\% funding goal), and manages investments. }\end{array}$ & $\begin{array}{l}\text { SERS members have } \\
\text { access to SS benefits, } \\
\text { but TRS members } \\
\text { (teachers) do not. IMRF } \\
\text { members have access to } \\
\text { SS benefits. }\end{array}$ \\
\hline Indiana & $\begin{array}{l}\text { - Indiana Public Retirement System (IPRS) } \\
\text { administrates/oversees nearly all the public retirement plans } \\
\text { (including state, teachers, localities, etc.) as of July } 12011 . \\
\text { - Teachers have the TRF (Teachers Retirement Fund), and } \\
\text { fire, police, judges and other groups have their own funds } \\
\text { under IPRS.Localities must join PERF (Public Employees } \\
\text { Retirement Fund) under IPRS. } \\
\text { - There is both a Defined Benefit and an Annuity Savings } \\
\text { Account (ASA) plan } \\
\text { - Employees must have both with required contributions to the } \\
\text { ASA. } \\
\text { - PERF determines benefits and contributions } \\
\text { INPRS is responsible for investing for DB; ASA has more } \\
\text { flexibility. }\end{array}$ & $\begin{array}{l}\text { Members of the PERF, } \\
\text { DROP, Judicial, Excise } \\
\text { Police, PARF } \\
\text { (prosecutors), the } \\
\text { Legislative DBP, and } \\
\text { TRF (teachers) plans } \\
\text { have access to SS } \\
\text { benefits. }\end{array}$ \\
\hline Iowa & - Most state and local employees are in Iowa Public Employee & IPERS members have \\
\hline
\end{tabular}




\begin{tabular}{|c|c|c|}
\hline & $\begin{array}{l}\text { Retirement System, which has a defined benefit plan. } \\
\text { - IPERS determines benefits, but there are different benefit } \\
\text { plans for new vs. old employees vs. retirees, and so on. } \\
\text { Sheriffs, firefighters and similar groups have different } \\
\text { benefits. } \\
\text { - IPERS requires certain contribution rates. } \\
\text { - IPERS also has an investment committee. }\end{array}$ & access to SS benefits. \\
\hline Kansas & $\begin{array}{l}\text { - State plan is KPERS and is required for the state and school } \\
\text { districts. Under KPERS, police, fire and judges all have } \\
\text { slightly different plans. } \\
\text { Localities can opt to join if they want, but some, like } \\
\text { Wichita, have their own. Once a locality joins they cannot } \\
\text { opt out again. } \\
\text { KPERS determine benefits and contribution rates for } \\
\text { member localities } \\
\text { - Chief Investment Officer takes care of member localities' } \\
\text { investments, if they choose to join KPERS. }\end{array}$ & $\begin{array}{l}\text { KPERS members have } \\
\text { access to SS benefits. }\end{array}$ \\
\hline Kentucky & $\begin{array}{l}\text { - Kentucky Retirement Systems oversees pensions for state } \\
\text { employees (KERS), county employees (CERS), and state } \\
\text { police, and they are defined benefit plans. } \\
\text { - There are also plans for teachers, judges, etc. } \\
\text { - It appears most cities/towns are in the CERS but it's not } \\
\text { clear that it's mandatory. } \\
\text { - KRS determines benefits and contribution rates for those in } \\
\text { KERS/CERS, and there is an investment committee made up } \\
\text { of members of the board of trustees. }\end{array}$ & $\begin{array}{l}\text { KERS members have } \\
\text { access to SS benefits. } \\
\text { KTRS (teachers) } \\
\text { members do not } \\
\text { participate in SS. }\end{array}$ \\
\hline Louisiana & $\begin{array}{l}\text { - The Louisiana State Employees' Retirement System } \\
\text { (LASERS) provide benefits to many state employees. } \\
\text { Teachers have their own. } \\
\text { - Some localities have to have their own systems. New } \\
\text { Orleans and Baton Rouge are two. However, there is a } \\
\text { municipal system (MERSLA) that localities can join if they } \\
\text { want, which is a DB plan. } \\
\text { - If a member of MERSLA, it determines benefits and } \\
\text { contribution rates. } \\
\text { - MERSLA handles investments. }\end{array}$ & $\begin{array}{l}\text { Neither LASERS nor } \\
\text { TRSL members } \\
\text { (teachers) participate in } \\
\text { SS. }\end{array}$ \\
\hline Maine & $\begin{array}{l}\text { - } \quad \text { "Since 1942, the Maine Public Employees Retirement } \\
\text { System (MainePERS) has helped public employees prepare } \\
\text { for retirement. The System's contributing members include } \\
\text { teachers, state, county, and municipal employees, legislators, } \\
\text { judges, and those who work for other public entities." } \\
\text { - Counties and Municipalities are part of PERS. "Participating } \\
\text { Local Districts" are other public entities that can choose to } \\
\text { participate } \\
\text { - The Board determines benefits. } \\
\text { - Contribution rates are defined by law and depend on the plan } \\
\text { chosen/required. } \\
\text { - The executive director manages the system, the Board } \\
\text { manages investments. } \\
\text { The plan is DB, but there is an optional additional DC plan } \\
\text { in which employees have a lot more flexibility with } \\
\text { investments. }\end{array}$ & $\begin{array}{l}\text { MainePERS members } \\
\text { do not participate in SS. }\end{array}$ \\
\hline Maryland & $\begin{array}{ll}\text { - The State Retirement and Pension System (SRPS) include } \\
\text { state employees, teachers, state police, judges, law }\end{array}$ & $\begin{array}{l}\text { SPRS members have } \\
\text { access to SS benefits. }\end{array}$ \\
\hline
\end{tabular}




\begin{tabular}{|c|c|c|}
\hline & $\begin{array}{l}\text { enforcement officers, correctional officers and legislators. } \\
\text { Main plan seems to be DB, but there are different plans and } \\
\text { differences depending on when the employee was hired. } \\
\text { Local governments can voluntarily participate, but some, } \\
\text { like the City of Baltimore, have their own systems in place. } \\
\text { - SRPS determines different plans with different benefits and } \\
\text { employer contribution rates. And if a member of SRPS, the } \\
\text { Board manages the investments. }\end{array}$ & \\
\hline Massachusetts & $\begin{array}{l}\text { PERAC oversees all retirement boards at the state and local } \\
\text { level. } \\
\text { Many local boards, and some have joined the State system } \\
\text { voluntarily. They can be forced to join if certain } \\
\text { requirements aren't met. Massachusetts law establishes } \\
\text { benefits, contribution requirements and accounting/funding, } \\
\text { PERAC/Massachusetts law oversees/manages everything for } \\
\text { its members. } \\
\text { PRIM (Pension Reserves Investment Management) oversees } \\
\text { investments of the Pension Reserves Investment Trust } \\
\text { (PRIT), which invests money from the State Employee and } \\
\text { Massachusetts Teachers Systems, and the systems of any } \\
\text { localities that decide to join. }\end{array}$ & $\begin{array}{l}\text { PERAC members do } \\
\text { not participate in SS. }\end{array}$ \\
\hline Michigan & $\begin{array}{l}\text { Michigan has a state system, also ones for teachers, police, } \\
\text { and judges. } \\
\text { Many localities are in the Municipal Employee Retirement } \\
\text { System (MERS of Michigan), but it is not required, as } \\
\text { Detroit has its own system. It's a public company since } 1996 . \\
\text { There are DB, DC, and Hybrid plans, with some flexibility } \\
\text { of choice. } \\
\text { Benefits, contributions, and investments are determined by } \\
\text { MERS if a member. DC and Hybrid have more investment } \\
\text { flexibility. There is also an option to invest in the MERS } \\
\text { funds without being a member. }\end{array}$ & $\begin{array}{l}\text { Most MERS members } \\
\text { have access to SS } \\
\text { benefits. PSERS, } \\
\text { SEDBP and MSPRS } \\
\text { members have access to } \\
\text { SS benefits. }\end{array}$ \\
\hline Minnesota & $\begin{array}{l}\text { The Minnesota State Retirement fund includes a general } \\
\text { fund, then funds for police, correctional officers, judges, } \\
\text { legislators, and state officers, and also teachers. } \\
\text { The Public Employees Retirement Association is required } \\
\text { for cities/towns/municipalities. } \\
\text { - It's a defined benefit plan, but some employees have an } \\
\text { option to do a DC plan and have more individual flexibility. } \\
\text { - Benefits and contributions are determined by PERA } \\
\text { MN State Board of Investment handles the investments for } \\
\text { the plans. }\end{array}$ & $\begin{array}{l}\text { MSRS members have } \\
\text { access to SS benefits. } \\
\text { Most MNPERA } \\
\text { members have access to } \\
\text { SS benefits. }\end{array}$ \\
\hline Mississippi & $\begin{array}{l}\text { PERS (Public Employee Retirement Systems) covers almost } \\
\text { all public employees, and offers a DB plan. } \\
\text { For employees hired before the individual municipality plan } \\
\text { was closed, they are grandfathered in to the old city plan } \\
\text { with its contribution rates and benefits. New employees go } \\
\text { under PERS. } \\
\text { - PERS determines benefits, but localities have some } \\
\text { flexibility at the local level. May be different for the } \\
\text { grandfathered employees under old defunct municipal plans. } \\
\text { PERS board can set the contribution rates, and has increased } \\
\text { them recently to deal with shortfalls. Rates may be different }\end{array}$ & $\begin{array}{l}\text { PERS members have } \\
\text { access to SS benefits. } \\
\text { Members of } \\
\text { grandfathered MUNI } \\
\text { plans may or may not } \\
\text { have SS benefits if their } \\
\text { plan opted out. }\end{array}$ \\
\hline
\end{tabular}




\begin{tabular}{|c|c|c|}
\hline & $\begin{array}{l}\text { for the grandfathered employees under old defunct municipal } \\
\text { plans. } \\
\text { The Board of Trustees serves as the ultimate decision- } \\
\text { making body for the Public Employees' Retirement System } \\
\text { of Mississippi, including investments. }\end{array}$ & \\
\hline Missouri & $\begin{array}{l}\text { MOSERS (Missouri State Employees' Retirement System) is } \\
\text { the system for state employees, and covers many groups } \\
\text { such as public safety, judges etc. } \\
\text { - Also a public schools retirement system. } \\
\text { For Local Government Employees' Retirement System } \\
\text { (LAGERS) localities (cities, counties, etc) can opt to join } \\
\text { their DB plan. But some have their own plans, for instance, } \\
\text { St. Louis. } \\
\text { - } \quad \text { LGERS determines benefits for its members. } \\
\text { - State law says the employee must pay in } 4 \% \text { but the } \\
\text { employer payment can vary. It appears this } 4 \% \text { rule extends } \\
\text { to local governments that are not party of LGERS. } \\
\text { LAGER has its own investment portfolio. }\end{array}$ & $\begin{array}{l}\text { MOSERS and } \\
\text { MOLAGERS members } \\
\text { have access to SS } \\
\text { benefits. PSRS/PEERS } \\
\text { members (teachers) do } \\
\text { not participate in SS. }\end{array}$ \\
\hline Montana & $\begin{array}{l}\text { PERS covers state, university of Montana, local } \\
\text { governments and some school districts, under MPERA } \\
\text { (Montana Public Employee Retirement Administration). } \\
\text { - Also under MPERA, systems for judges, police officers, } \\
\text { sheriffs, firefighters and so on. } \\
\text { - Under PERS, there is a defined benefit and defined } \\
\text { contribution plan. } \\
\text { - PERS determines benefits for DB For DC there is more } \\
\text { variation. } \\
\text { - PERS determines contribution rates for DB and DC. } \\
\text { MPERA manages/oversees PERS. There is an investment } \\
\text { board with DB, but more flexibility with DC in terms of } \\
\text { investments. }\end{array}$ & $\begin{array}{l}\text { MPERS members have } \\
\text { access to SS benefits. }\end{array}$ \\
\hline Nebraska & $\begin{array}{l}\text { - State, county, school, judges, and patrol employees are under } \\
\text { the Nebraska Public Employees Retirement Systems . State } \\
\text { and county plans are DC. } \\
\text { - Smaller localities (i.e. cities) seem to be allowed to have } \\
\text { their own plans. For instance, Omaha has its own civilian } \\
\text { and firefighter/police pension systems, as indicated in its } \\
\text { budget line items. } \\
\text { - For counties, required to follow the county plans, and there } \\
\text { is a benefit calculator indicating benefits are defined by the } \\
\text { plan. } \\
\text { - For counties, required to follow the county plans, and } \\
\text { contributions are determined by the board. } \\
\text { For counties, required to follow the county plan, but } \\
\text { investments are made individually in DC, but by the board in } \\
\text { cash balance benefit plan. }\end{array}$ & $\begin{array}{l}\text { In the NPERS system, } \\
\text { State Employees do not } \\
\text { participate in SS, but } \\
\text { other public employees } \\
\text { do. }\end{array}$ \\
\hline Nevada & $\begin{array}{l}\text { - Almost all public employees are in PERS (Public Employee } \\
\text { Retirement System). } \\
\text { - There are slightly different plans under PERS for groups } \\
\text { like firefighters, judges and legislators. } \\
\text { - There is a Employer Pay Contribution Plan (ERPaid) and an } \\
\text { Employee/Employer Contribution Plan, and some } \\
\text { differences in plans depending on time of hire and so on. } \\
\text { - } \quad \text { PERS determines benefits and rates, and PERS has its own }\end{array}$ & $\begin{array}{l}\text { NVPERS members do } \\
\text { not participate in SS. }\end{array}$ \\
\hline
\end{tabular}




\begin{tabular}{|c|c|c|}
\hline & investment fund. & \\
\hline New Hampshire & $\begin{array}{l}\text { New Hampshire Retirement System is for state, teachers, } \\
\text { police and fire, and participating smaller localities, and is a } \\
\text { contributory defined benefit plan. } \\
\text { Most smaller localities participate in the NHRS, but it's not } \\
\text { required. } \\
\text { - NHRS determines for its members benefits and contribution } \\
\text { rates and manages the system and investments through a } \\
\text { board of trustees. }\end{array}$ & $\begin{array}{l}\text { NHRS members, except } \\
\text { for Police and Fire } \\
\text { members, have access } \\
\text { to SS benefits. }\end{array}$ \\
\hline New Jersey & $\begin{array}{l}\text { PERS is the general statewide system. There are separate } \\
\text { funds for Teachers, FF, Police, Judges } \\
\text { - Joining PERS is optional for smaller localities, but it seems } \\
\text { like most do join. } \\
\text { - Under PERS, benefits and contributions are determined, with } \\
\text { employers required to fund contributions each year. PERS } \\
\text { also manages investments. }\end{array}$ & $\begin{array}{l}\text { PERS members have } \\
\text { access to SS benefits. }\end{array}$ \\
\hline New Mexico & $\begin{array}{l}\text { - PERS manages state, county, municipals along with } \\
\text { firefighters etc. } \\
\text { - PERS determines benefits, with slightly different benefits for } \\
\text { different groups (i.e. firefighters) and some flexibility with } \\
\text { plan choice for the employer. They are defined benefit plans. } \\
\text { - Recent changes under PERS included an increase in required } \\
\text { contributions. Rates can vary depending if it's state, county, } \\
\text { firefighters, etc, and there are a few different plans. } \\
\text { - The Board, in investing PERA assets according to the } \\
\text { Investment Policy . }\end{array}$ & $\begin{array}{l}\text { PERS members have } \\
\text { access to SS benefits. }\end{array}$ \\
\hline New York & $\begin{array}{l}\text { - New York State and Local Retirement System (NYSLRS) } \\
\text { consists of the New York State and Local Employees' } \\
\text { Retirement System and the New York State and Local Police } \\
\text { and Fire Retirement System. } \\
\text { - New York City has its own, NYCERS. Under this system is } \\
\text { has plans for teachers, police fire, etc. } \\
\text { - In NYSLRS, Tiers based on dates of hire determine benefits } \\
\text { and contribution rates } \\
\text { - As for investments, New York State Common Retirement } \\
\text { Fund is for state and most local public employees. NYC has } \\
\text { its own system though, and manages it own its own. }\end{array}$ & $\begin{array}{l}\text { NYSLRS and NYCERS } \\
\text { members have access to } \\
\text { SS benefits. }\end{array}$ \\
\hline North Carolina & $\begin{array}{l}\text { - State and teachers (who have their own). Also judges and } \\
\text { legislatures have their own. } \\
\text { - Mostly DB, but employees can add DC/401k to supplement. } \\
\text { - There is a local system (general and law enforcement) that } \\
\text { local areas can opt into. Seems like most choose to. } \\
\text { - If a member of the system, it determines benefits, } \\
\text { contribution rates, and investments. }\end{array}$ & $\begin{array}{l}\text { TSERS and LGERS } \\
\text { members have access to } \\
\text { SS benefits. }\end{array}$ \\
\hline North Dakota & $\begin{array}{l}\text { - PERS system covers state and participating political } \\
\text { subdivisions. It seems like most subdivision do participate. } \\
\text { City of Bismarck, for instance, is not in PERS but its school } \\
\text { districts and firefighters are. } \\
\text { - There are both DB and DC plans, but some restrictions on } \\
\text { who can participate in DC. } \\
\text { Benefits and contribution rates are set for members of PERS } \\
\text { North Dakota State Investment Board manages investments } \\
\text { for those in PERS. }\end{array}$ & $\begin{array}{l}\text { NDPERS members } \\
\text { have access to SS } \\
\text { benefits. }\end{array}$ \\
\hline Ohio & - There is a State program (that covers local too) as well as a & OPERS members do not \\
\hline
\end{tabular}




\begin{tabular}{|c|c|c|}
\hline & $\begin{array}{l}\text { - } \quad \text { separate teacher fund and one for fire/police. } \\
\text { - } \quad \text { There are both DB and DC plans } \\
\text { - } \quad \text { Members of OPERS have OPERS determine benefits, } \\
\text { contributions, and investments, with more flexibility for } \\
\text { investments in the DC plan }\end{array}$ & participate in SS. \\
\hline Oklahoma & $\begin{array}{l}\text { - There is a state retirement fund along with separate ones for } \\
\text { teachers and police. } \\
\text { There is a municipal retirement fund. Many cities are } \\
\text { members, but doesn't look like it's mandatory. } \\
\text { - } \quad \text { Several plans (DC, DB) } \\
\text { OKMRF determines the benefits, but there are several cities } \\
\text { can choose from. Contributions are determined by OKMRF } \\
\text { for DB. } \\
\text { For contributions, DC is more flexible on the local level. } \\
\text { There is a specific OMRF fund for DB. DC has a bit more } \\
\text { flexibility. } \\
\text { A board of trustees from the different districts of the state is } \\
\text { the administrators. }\end{array}$ & $\begin{array}{l}\text { OPERS and OKMRF } \\
\text { members have access to } \\
\text { SS benefits. }\end{array}$ \\
\hline Oregon & $\begin{array}{l}\text { - Oregon Public Service Retirement Plan for state and local, } \\
\text { - } \quad \text { Almost 95\% of public employees are in it, including teachers. } \\
\text { - Seems to be a hybrid plan, with both DB and DC } \\
\text { components for each member. } \\
\text { - Public Employee Retirement Fund (PERS) sets benefits and } \\
\text { contribution requirements. Treasury and OIC (Oregon } \\
\text { Investment Council) are in charge of investments. }\end{array}$ & $\begin{array}{l}\text { OPSRP members have } \\
\text { access to SS benefits. }\end{array}$ \\
\hline Pennsylvania & $\begin{array}{l}\text { - The State plan is SERAS and a separate one for teachers. } \\
\text { PMRS is the local system, but it is not required. However, if } \\
\text { plans are under distress, there can be requirements for } \\
\text { making changes under PA law. } \\
\text { - PMRS has plan flexibility for localities, with a DB and Cash } \\
\text { Benefit option. } \\
\text { Members of PMRS work with PMRS to determine benefits. } \\
\text { Contribution rates and investments are also determined by } \\
\text { PMRS for members. }\end{array}$ & $\begin{array}{l}\text { PMRS and SERS } \\
\text { members have access to } \\
\text { SS benefits. }\end{array}$ \\
\hline Rhode Island & $\begin{array}{l}\text { Employees Retirement System of Rhode Island covers state } \\
\text { employees, teachers, judges, state police and participating } \\
\text { municipalities. DB plan. } \\
\text { Localities can join ERS/MERS, but not required. } \\
\text { Providence for instance isn't part of MERS, and is having } \\
\text { issues with its pension plan. } \\
\text { - Under ERS's MERS (municipal employee retirement } \\
\text { system), benefits, contributions and investments are } \\
\text { determined for those municipalities that participate. }\end{array}$ & $\begin{array}{l}\text { ERSRI members have } \\
\text { access to SS benefits. }\end{array}$ \\
\hline South Carolina & $\begin{array}{l}\text { - The South Carolina Retirement Systems is for state } \\
\text { employees and public and charter school educators. } \\
\text { Localities can opt to join in. There are other systems for } \\
\text { judges, police officers, etc. } \\
\text { - Members of the state plan can choose the default DB or the } \\
\text { optional DC. } \\
\text { - If in SCRS, SCRS determines benefits and contribution } \\
\text { rates. } \\
\text { - If in SCRS, SCRS manages, and the South Carolina }\end{array}$ & $\begin{array}{l}\text { SCRS members have } \\
\text { access to SS benefits. }\end{array}$ \\
\hline
\end{tabular}




\begin{tabular}{|c|c|c|}
\hline & $\begin{array}{l}\text { Retirement System Investment Commission invests. DC } \\
\text { plans have more investment flexibility. }\end{array}$ & \\
\hline South Dakota & $\begin{array}{l}\text { The South Dakota Retirement System covers state, local, } \\
\text { teachers, etc, and is a defined benefit plan. } \\
\text { Benefits are determined by SDRS and there are mandatory } \\
\text { contribution rates under SDRS. } \\
\text { - SDRS also puts out a report for the government about the } \\
\text { unfunded liability. } \\
\text { - South Dakota Investment Council (SDIC) manages the } \\
\text { portfolio. } \\
\text { The South Dakota Retirement System Board of Trustees is } \\
\text { the governing authority of SDRS. }\end{array}$ & $\begin{array}{l}\text { SDRS members have } \\
\text { access to SS benefits. }\end{array}$ \\
\hline Tennessee & $\begin{array}{l}\text { - } \\
\text { a defined bennessee Consolid pension plan that covers state employees, } \\
\text { higher education employees, K-12 public school teachers, } \\
\text { and employees of political subdivisions who have elected to } \\
\text { participate in the plan. This means that the amount of any } \\
\text { future retirement benefits is determined by a benefit formula } \\
\text { rather than an account balance." } \\
\text { - The City of Memphis has their own system. However, due to } \\
\text { unfunded pension liability, the cities made changes to the } \\
\text { plan last year. This didn't appear to come down as a mandate } \\
\text { from the state, however, nor were they forced to join TCRS. } \\
\text { If local government elects to participate, benefits determined } \\
\text { by TCRS. The plan is DB but there are contributory and non- } \\
\text { contributory plans that the local government can choose. } \\
\text { If local government elects to participate, contributions of 5\% } \\
\text { are required. The plan is DB but there are contributory and } \\
\text { non-contributory plans that the local government can choose } \\
\text { The Board of Trustees picks an investment committee who } \\
\text { deals with the investments for those under the plan. }\end{array}$ & $\begin{array}{l}\text { TCRS members have } \\
\text { access to SS benefits. }\end{array}$ \\
\hline Texas & $\begin{array}{l}\text { - There is a pension review board that oversees state and local. } \\
\text { The attorney general keeps track of the health of plans. } \\
\text { - There is a state wide pension system, one for teachers, and } \\
\text { one for emergency services. } \\
\text { - The Texas municipal retirement system is not required for } \\
\text { localities. } \\
\text { Also a county and district plan, also not required. TCDRS is } \\
\text { not state funded but looked at by the legislature. } \\
\text { It seems some benefits are the same for all cities, if you join } \\
\text { TMRS, but cities do have some flexibility. Not for TCDRS, } \\
\text { as the county/district determines benefits. } \\
\text { - It appears cities determine the contribution rate. In TCDRS, } \\
\text { there is a requirement that } 100 \% \text { must be paid. } \\
\text { - If a member of TMRS, it determines the investments. }\end{array}$ & $\begin{array}{l}\text { ERS members (state } \\
\text { employees, judges, } \\
\text { elected officials) have } \\
\text { access to SS benefits, as } \\
\text { do TCDRS members. } \\
\text { Most TRS members } \\
\text { (teachers) do not } \\
\text { participate in SS. TMRS } \\
\text { members may or may } \\
\text { not participate in SS. }\end{array}$ \\
\hline Utah & $\begin{array}{l}\text { - There is a Public Employees system for state, local and } \\
\text { teachers, then others for judges, public safety, etc. There is } \\
\text { both a contributory and a noncontributory plan for Public } \\
\text { Employees. New employees must choose the DC or Hybrid } \\
\text { (401 and pension) plans. Employees before July 1, } 2011 \\
\text { have the Tier } 1 \text { (pension only plan).. } \\
\text { Benefits and contributions are determined for everyone } \\
\text { under the plan. } \\
\text { - If employers choose defined contribution under the system, }\end{array}$ & $\begin{array}{l}\text { URS members have } \\
\text { access to SS benefits. }\end{array}$ \\
\hline
\end{tabular}




\begin{tabular}{|c|c|c|}
\hline & $\begin{array}{l}\text { then employees can invest as they choose. } \\
\text { Utah State Retirement Board (Board) has statutory authority } \\
\text { to pool pension assets in the Utah Retirement Investment } \\
\text { Fund (Fund) for the defined benefit plan. }\end{array}$ & \\
\hline Vermont & $\begin{array}{l}\text { - } \quad \text { VERS (Vermont State Employees Retirement System) is the state } \\
\text { - } \quad \text { Teachers have their own (VSTRS). } \\
\text { - } \quad \text { Vermont Municipal Employees' Retirement System (VMERS) is } \\
\text { - } \quad \text { Ape local system, and is mandatory. } \\
\text { - } \quad \text { VMERS Board of Trustees is responsible for benefits. } \\
\text { - } \quad \text { VMERS dictates how much must be contributed. } \\
\text { - VMERS Board of Trustees is responsible for administration. }\end{array}$ & $\begin{array}{l}\text { VMERS, VSTRS and } \\
\text { VSRS members have } \\
\text { access to SS benefits. }\end{array}$ \\
\hline Virginia & $\begin{array}{l}\text { - Virginia Retirement System for State employees, teachers/school } \\
\text { employees, police, judges. Localities may choose to join. } \\
\text { Also, plan is required for "Any participating Virginia city, county, } \\
\text { town with a population of 5,000 or more if a local plan does not } \\
\text { provide a retirement plan for its employees that equals or exceeds } \\
\text { two-thirds of the service retirement benefit which } \\
\text { a VRS retiree would receive at age } 65 \text { or older." } \\
\text { - There are different plans depending on date of hire, but they are } \\
\text { defined benefit } \\
\text { - Looks like there is a defined contribution benefit option for some } \\
\text { employers, but it seems like the majority are DB. } \\
\text { If a member of VRS, VRS determines benefits, contribution rates, } \\
\text { and investments. }\end{array}$ & $\begin{array}{l}\text { VRS members have } \\
\text { access to SS benefits. }\end{array}$ \\
\hline Washington & $\begin{array}{l}\text { - Washington has State and Local plan, then ones for teachers, } \\
\text { - } \quad \text { Mublic safety, law enforcement, firefighters, and judges. } \\
\text { own. } \\
\text { - } \quad \text { Plans are defined benefit, and vary slightly depending on } \\
\text { hiring date, etc. } \\
\text { - The plan determines benefits for its members. } \\
\text { For members, there are required contribution rates. } \\
\text { Washington State Investment Board is responsible for } \\
\text { investments of State and Local Government plans and their } \\
\text { members. }\end{array}$ & $\begin{array}{l}\text { PERS, TRS, SERS, } \\
\text { LEOFF, WSPRS, } \\
\text { PSERS, JRS, and } \\
\text { SCERS members have } \\
\text { access to SS benefits. }\end{array}$ \\
\hline West Virginia & $\begin{array}{l}\text { - There is a Public Employees Retirement System, which } \\
\text { covers state and local employees, along with a bunch of } \\
\text { others for teachers, state troopers, judges, etc. } \\
\text { - For PERS members, benefits and contribution are } \\
\text { determined by PERS. } \\
\text { - For PERS, West Virginia Investment Management Board } \\
\text { manages the investments. }\end{array}$ & $\begin{array}{l}\text { PERS members do } \\
\text { have access to SS. }\end{array}$ \\
\hline Wisconsin & $\begin{array}{l}\text { - The Wisconsin Retirement System (WRS) covers employees } \\
\text { of the State of Wisconsin including school districts } \\
\text { (mandatory) and employees of local government employers } \\
\text { who elect to participate, and Milwaukee Public School } \\
\text { District teachers. } \\
\text { Most local governments participate in WRS. All counties } \\
\text { participate except Milwaukee county. Employees of the City } \\
\text { of Milwaukee and Milwaukee County are covered under } \\
\text { different pension systems, possibly other cities are as well. } \\
\text { - Calculates the benefits in a DB and DC way, and chooses the }\end{array}$ & $\begin{array}{l}\text { WRS members have } \\
\text { access to SS benefits. }\end{array}$ \\
\hline
\end{tabular}




\begin{tabular}{|c|c|c|}
\hline & 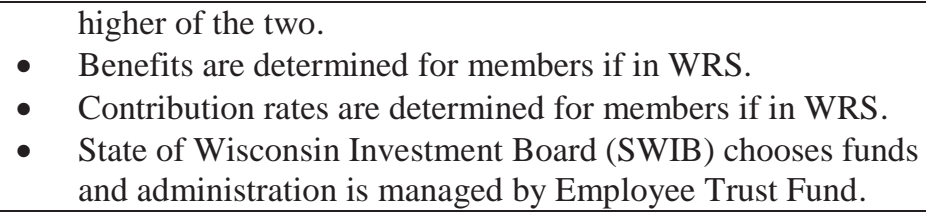 & \\
\hline Wyoming & $\begin{array}{l}\text { - State Employees, public teachers, and local governments are } \\
\text { in the Public Employee Pension System. However, } \\
\text { Wyoming Retirement Systems "consists of nine separate } \\
\text { retirement programs; the Public Employees Pension System, } \\
\text { the Warden, Patrol and DCI System, two Paid Firefighter } \\
\text { systems, the Volunteer Fire Pension System, Volunteer } \\
\text { Emergency Medical Technician Pension System, the Air } \\
\text { Guard Firefighter Pension System, the Law Enforcement } \\
\text { Pension System and the Judicial Pension System. As of July } \\
\text { 1, 2001, the Wyoming Deferred Compensation program is } \\
\text { administered by the Wyoming Retirement Board." } \\
\text { Mostly DB plans, but there is a DC option for some. } \\
\text { WRS determines the benefits. } \\
\text { "Wyoming statute requires a contribution of 14.12\% of } \\
\text { your salary monthly; you contribute 7.00\% and your } \\
\text { employer contributes 7.12\%. Your employer may fund } \\
\text { some or all the required employee's portion of the } \\
\text { contribution in addition to the employer's share. For } \\
\text { example, the State of Wyoming pays } 12.69 \% \text { of the } \\
\text { monthly contributions for its employees." From the public } \\
\text { pension employee handbook. } \\
\text { WRS Investment Board handles the investments. }\end{array}$ & $\begin{array}{l}\text { WRS members have } \\
\text { access to SS benefits. }\end{array}$ \\
\hline
\end{tabular}


TABLE 2:

STATE PENSION GENEROSITY

\begin{tabular}{|c|c|c|c|}
\hline State & $\begin{array}{l}\text { Average Benefits } \\
\text { per State or Local } \\
\text { Retiree (2010) }\end{array}$ & $\begin{array}{c}\text { Average Yearly } \\
\text { Wage for } \\
\text { Employees (2011) }\end{array}$ & Ratio \\
\hline Arizona & $\$ 22,306.52$ & $\$ 43,670.00$ & 0.51 \\
\hline Arkansas & $\$ 18,681.78$ & $\$ 36,340.00$ & 0.51 \\
\hline California & $\$ 30,229.98$ & $\$ 51,910.00$ & 0.58 \\
\hline Colorado & $\$ 33,831.45$ & $\$ 47,510.00$ & 0.71 \\
\hline Connecticut & $\$ 37,692.02$ & $\$ 52,830.00$ & 0.71 \\
\hline Delaware & $\$ 18,184.37$ & $\$ 47,420.00$ & 0.38 \\
\hline Florida & $\$ 20,095.67$ & $\$ 40,750.00$ & 0.49 \\
\hline Georgia & $\$ 27,872.32$ & $\$ 42,590.00$ & 0.65 \\
\hline Hawaii & $\$ 18,200.29$ & $\$ 44,600.00$ & 0.41 \\
\hline Idaho & $\$ 16,566.60$ & $\$ 38,520.00$ & 0.43 \\
\hline Illinois & $\$ 26,666.29$ & $\$ 46,550.00$ & 0.57 \\
\hline Indiana & $\$ 14,711.50$ & $\$ 39,700.00$ & 0.37 \\
\hline Iowa & $\$ 14,499.39$ & $\$ 38,820.00$ & 0.37 \\
\hline Kansas & $\$ 15,307.35$ & $\$ 40,030.00$ & 0.38 \\
\hline Kentucky & $\$ 21,567.46$ & $\$ 38,640.00$ & 0.56 \\
\hline Louisiana & $\$ 21,158.44$ & $\$ 38,780.00$ & 0.55 \\
\hline Maine & $\$ 18,156.39$ & $\$ 40,190.00$ & 0.45 \\
\hline Maryland & $\$ 21,019.71$ & $\$ 51,860.00$ & 0.41 \\
\hline Massachusetts & $\$ 31,315.40$ & $\$ 54,740.00$ & 0.57 \\
\hline Michigan & $\$ 18,744.37$ & $\$ 43,700.00$ & 0.43 \\
\hline Minnesota & $\$ 20,071.53$ & $\$ 46,150.00$ & 0.43 \\
\hline Mississippi & $\$ 20,019.30$ & $\$ 34,770.00$ & 0.58 \\
\hline Missouri & $\$ 22,646.89$ & $\$ 40,500.00$ & 0.56 \\
\hline Montana & $\$ 14,789.57$ & $\$ 36,840.00$ & 0.40 \\
\hline Nebraska & $\$ 20,604.00$ & $\$ 39,140.00$ & 0.53 \\
\hline Nevada & $\$ 29,601.73$ & $\$ 41,860.00$ & 0.71 \\
\hline New Hampshire & $\$ 19,089.74$ & $\$ 45,220.00$ & 0.42 \\
\hline New Jersey & $\$ 28,016.44$ & $\$ 51,540.00$ & 0.54 \\
\hline New Mexico & $\$ 21,386.27$ & $\$ 40,790.00$ & 0.52 \\
\hline New York & $\$ 25,221.17$ & $\$ 52,810.00$ & 0.48 \\
\hline North Carolina & $\$ 18,144.43$ & $\$ 41,250.00$ & 0.44 \\
\hline North Dakota & $\$ 14,419.65$ & $\$ 38,870.00$ & 0.37 \\
\hline Ohio & $\$ 25,726.10$ & $\$ 41,590.00$ & 0.62 \\
\hline Oklahoma & $\$ 17,706.57$ & $\$ 38,190.00$ & 0.46 \\
\hline Oregon & $\$ 26,228.58$ & $\$ 44,290.00$ & 0.59 \\
\hline Pennsylvania & $\$ 24,905.81$ & $\$ 44,070.00$ & 0.57 \\
\hline Rhode Island & $\$ 32,300.00$ & $\$ 47,390.00$ & 0.68 \\
\hline South Carolina & $\$ 18,951.58$ & $\$ 38,560.00$ & 0.49 \\
\hline South Dakota & $\$ 15,472.48$ & $\$ 35,390.00$ & 0.44 \\
\hline Tennessee & $\$ 13,690.77$ & $\$ 39,130.00$ & 0.35 \\
\hline Texas & $\$ 20,730.79$ & $\$ 43,090.00$ & 0.48 \\
\hline Utah & $\$ 21,345.94$ & $\$ 40,950.00$ & 0.52 \\
\hline Vermont & $\$ 15,683.37$ & $\$ 43,080.00$ & 0.36 \\
\hline Virginia & $\$ 20,440.11$ & $\$ 48,870.00$ & 0.42 \\
\hline Washington & $\$ 20,851.62$ & $\$ 50,280.00$ & 0.41 \\
\hline West Virginia & $\$ 15,434.50$ & $\$ 36,220.00$ & 0.43 \\
\hline Wisconsin & $\$ 25,204.68$ & $\$ 41,420.00$ & 0.61 \\
\hline Wyoming & $\$ 15,060.36$ & $\$ 42,510.00$ & 0.35 \\
\hline
\end{tabular}

Note: Average benefits data from the Census publication, "Public-

Employee Retirement Systems State- and Locally-Administered Pensions Summary Report: 2010”, by by Erika Becker-Medina. Average yearly wage data is from the Bureau of Labor Statistics, and is calculated for employees of all occupations (not just public sector). 


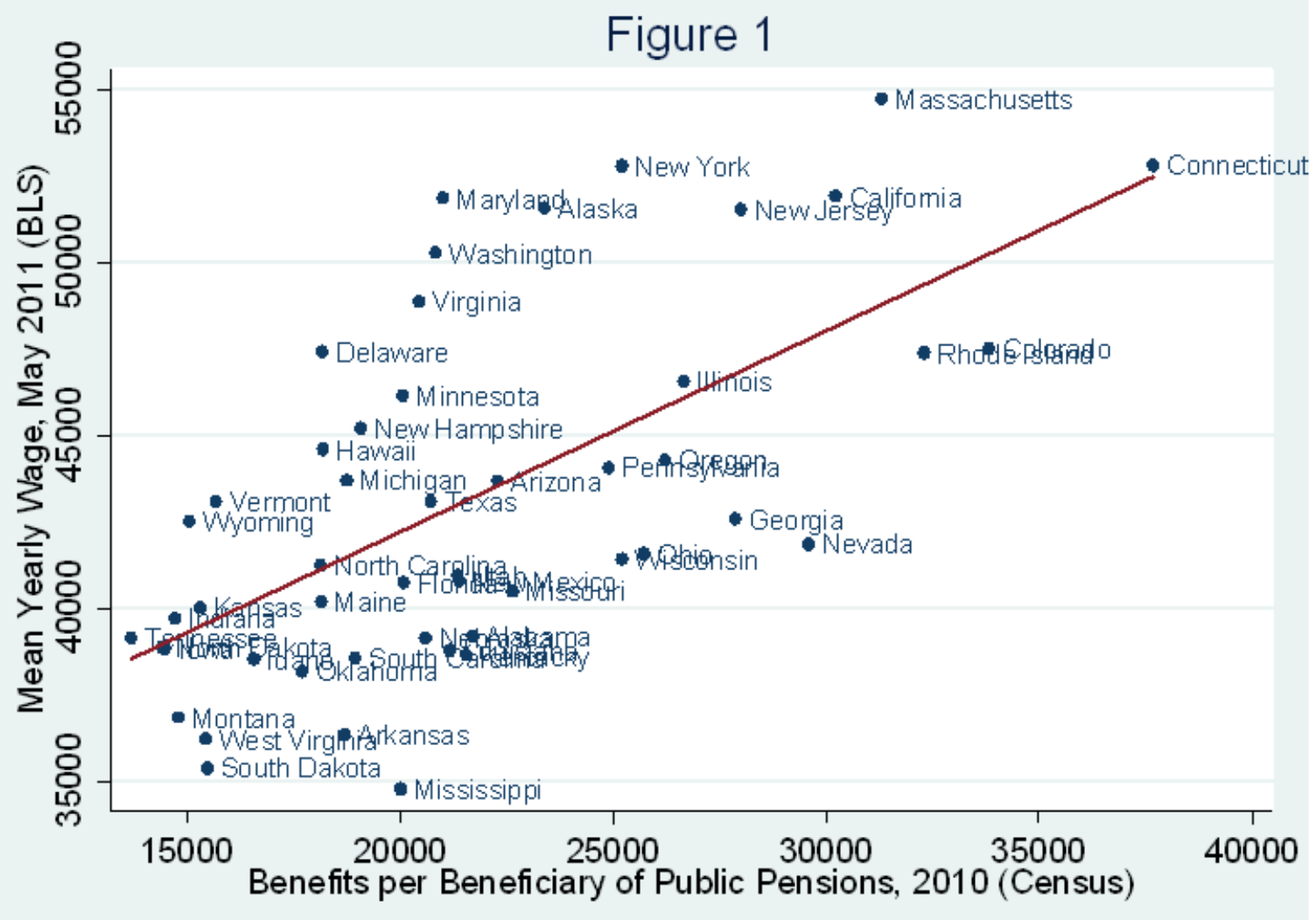

